\title{
Agricultural Economics and Rural Sociology
} and Agricultural Extension Research

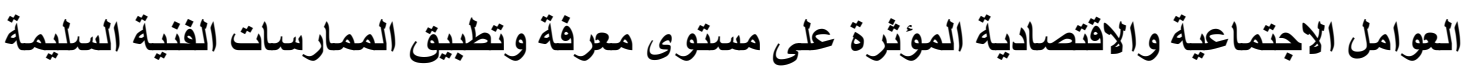 لمشروعات الاستزراع السمكى بمحافظة الثرقية}

\author{
أحمد مهدى اسماعيل1* ـ أيمن أحمد عكرش 1 سونيا محيى الدين نصرت² حازم محمد ابويحيى محمد سليم1 1 \\ 1- تخصص الاجتماع الريفي - قسم الاقتصاد الزر اعي ـ كلية الزراعة - جامعة الزقازيق - مصر \\ 2- قسم المجتمع الريفيـ معهد بحوث الإرشاد الزر اعى والتنمية الريفية ـ مركز البحوث الزر اعيةـ الجيزة ـ مصر
}

\section{Received: 29/01/2017 ; Accepted: 01/03/2017}

الملخص: استهدفت الدراسة التعرف على مستوى الامكانيات البشرية والمادية لمشروعات الاستزراع السمكى غبر

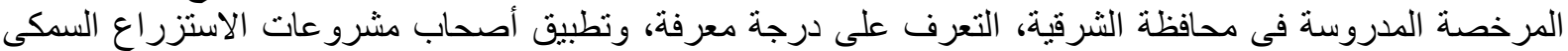

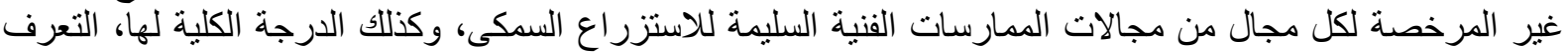

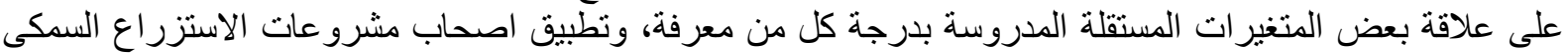

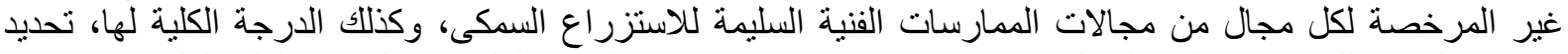

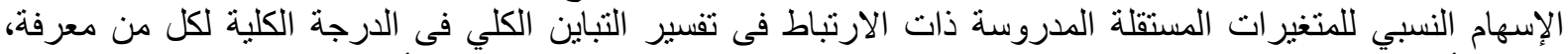

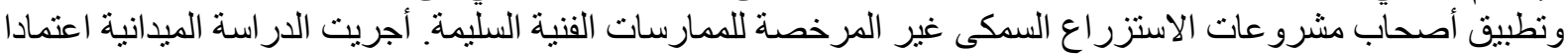

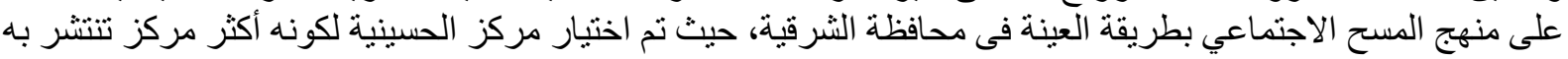

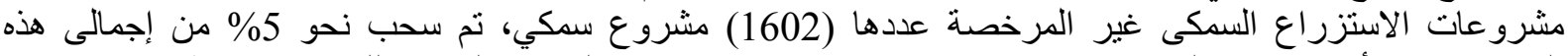

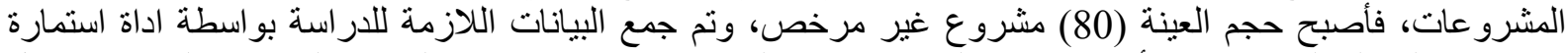

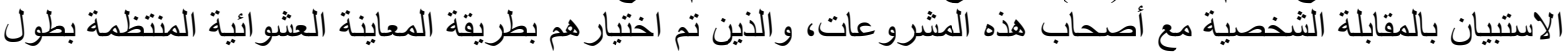

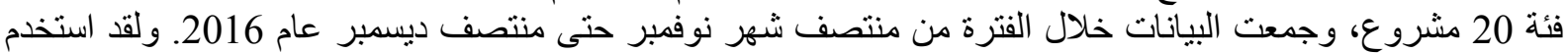

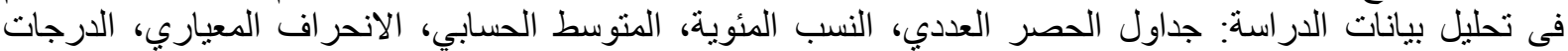

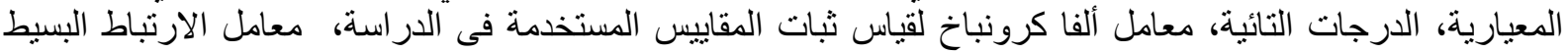

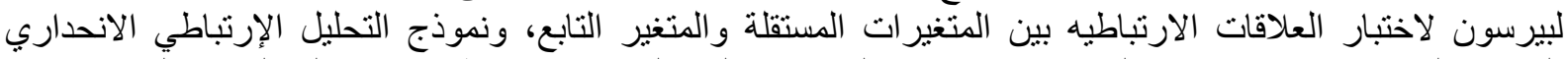

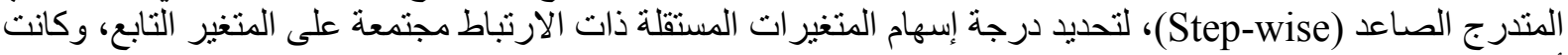

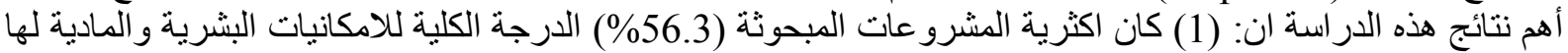

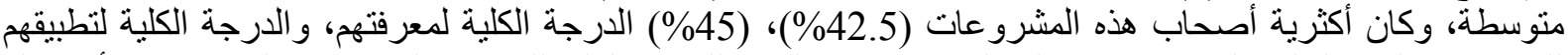

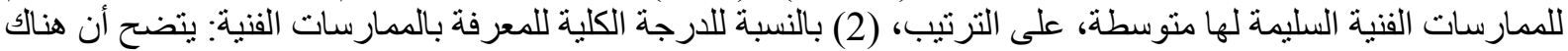

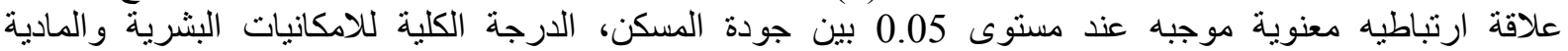

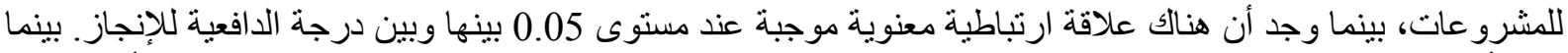

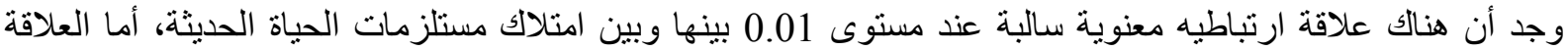

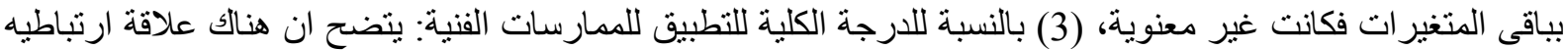

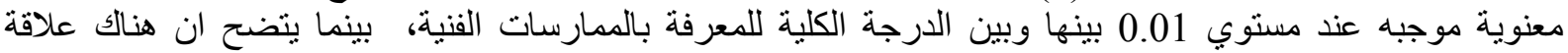

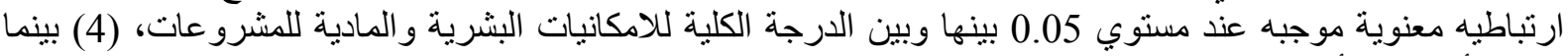

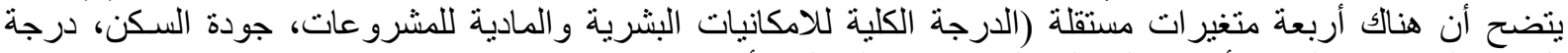

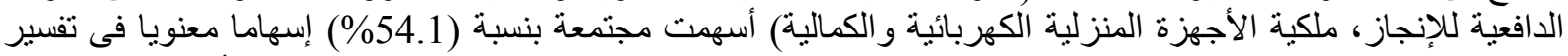

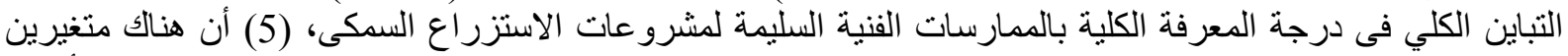

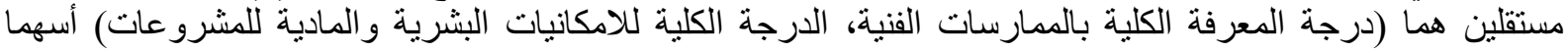
مجتمعين بنسبة (61.3\%) إسهاما معنويا في تفسير التباين الكلي فى درجة التطبيق الكلية للممارسات الفنية السليمة

$$
\text { لمشرو عات الاستزر اعنة السمكى المدروسة. }
$$

الكلمات الاسترشادية: مشرو عات الاستزراع السمكى، الممارسات الفنية السليمة، محافظة الثرقية.

\footnotetext{
${ }^{*}$ Corresponding author: Tel. : +201090352580

E-mail address: ahmedmahdy407@yahoo.com
} 
لتغذية الإنسان، وحيث أن موارد الثروة السمكية الطبيعية

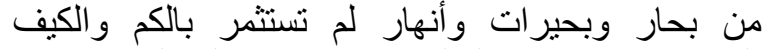
المناسب. فقد اتجه العالم منذ فترة طويلة إلى الاهني الكتمام

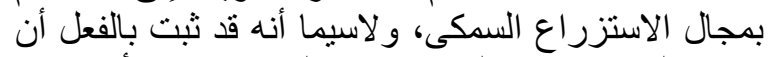

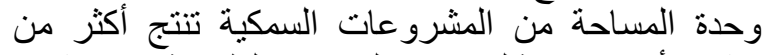

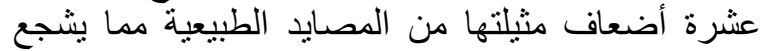

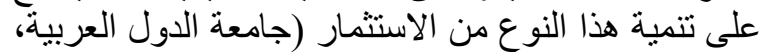

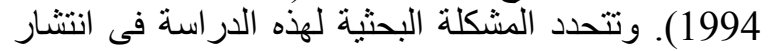

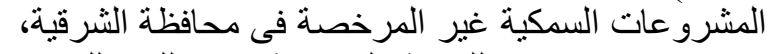

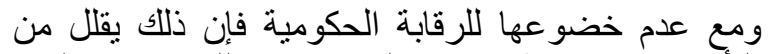

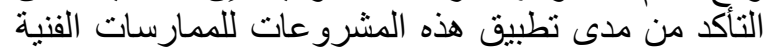

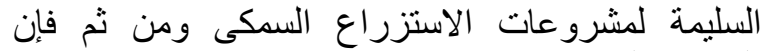

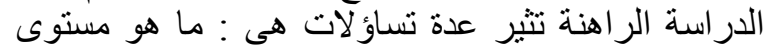

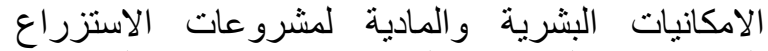

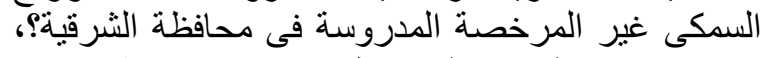

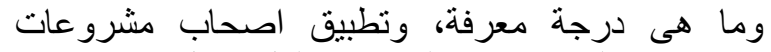

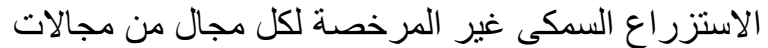

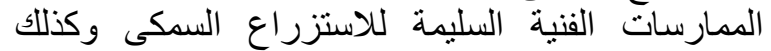

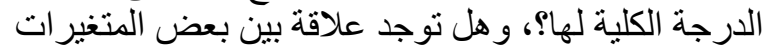

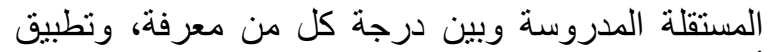

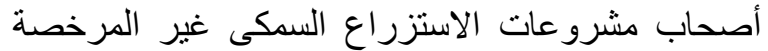

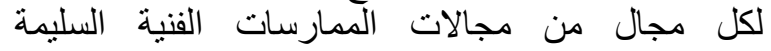

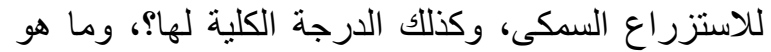

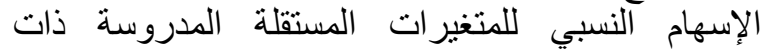

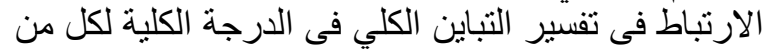

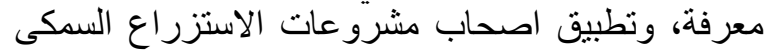

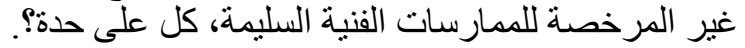

أهداف الدارسة المية

انطلاقا من أبعاد المشكلة البحثية السابقة، تستهدف هذه

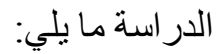

1- التعرف على مستوى الامكانيات البشرية والمادية

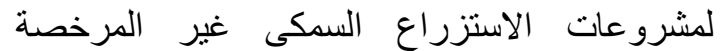
المدروسة فى محافظة الشرقية.

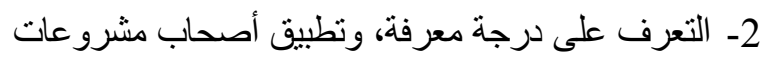

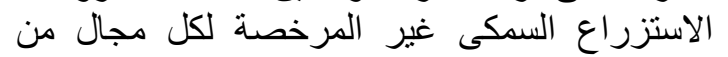
مجالات الممارسات الفنية السليمة للاستزر العيكة السمكى، وكذلك الدرجة الكلية لها، كل على حدى.

3- التعرف على العلاقة بين بعض المتغيرات المستقلة

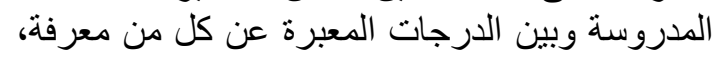

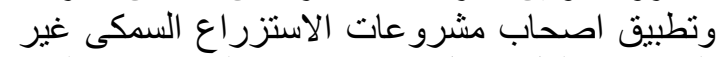

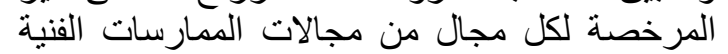
السليمة للاستزر اع السمكى، وكذللك الدرجة الكلية لها.

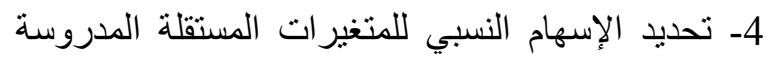
ذات الارتباط فى تفسير التباين الكلي فى الدرجة الكئ الكلية

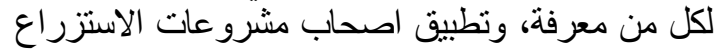
السمكى غير المرخصة للممارسات الفنية السليمة.

\section{المقدمة والمشكلة البحثية}

تلعب المشروعات الصغيرة ومتتاهية الصغر دورا

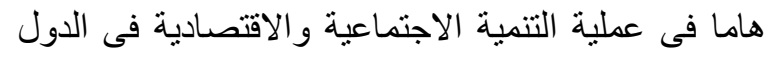

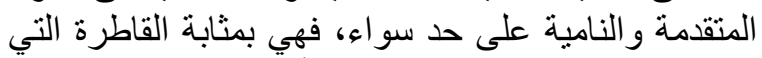

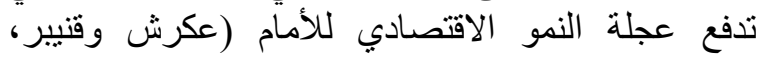

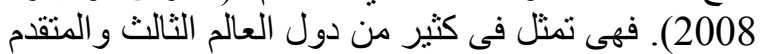

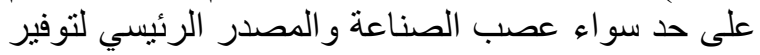
فرص العمل و الدخل (Liedholm, 1998).

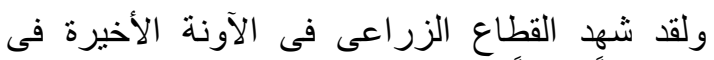

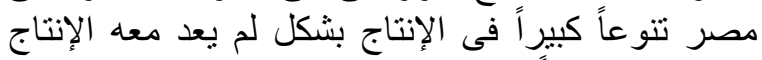

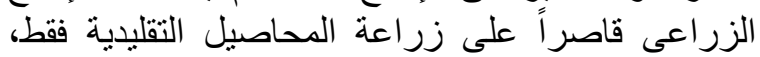

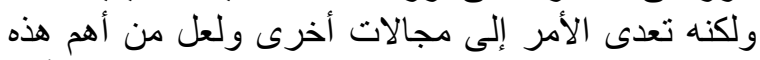

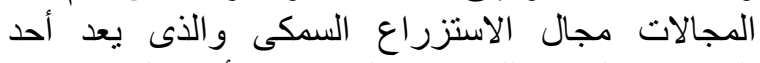

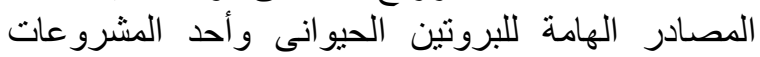

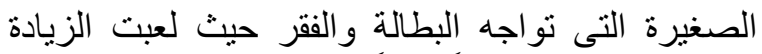

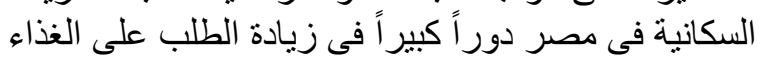

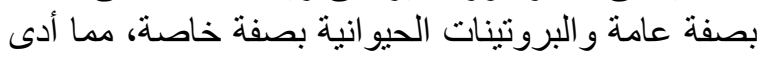

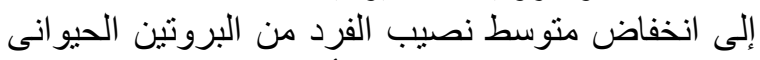

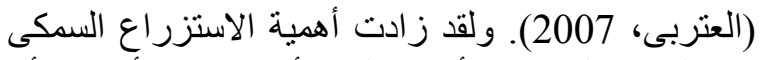

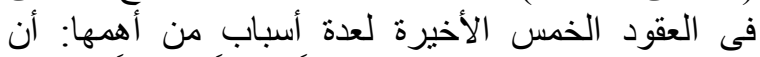

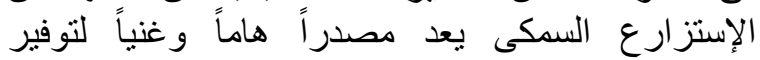

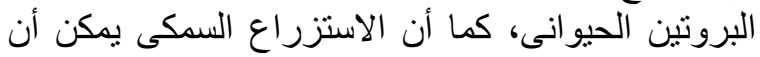

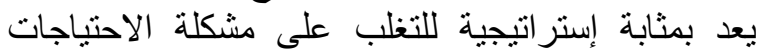

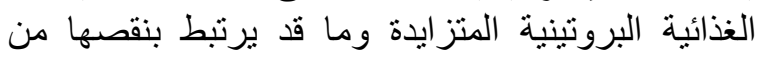

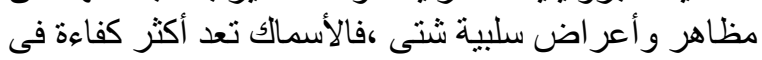

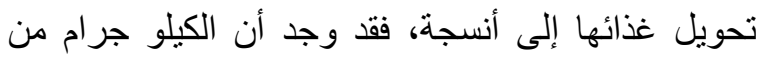

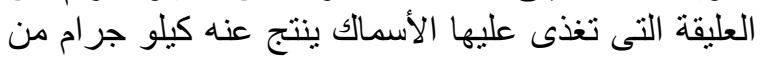

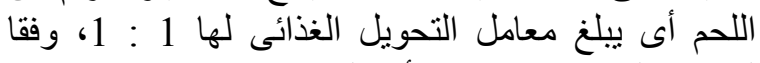

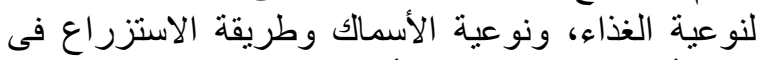

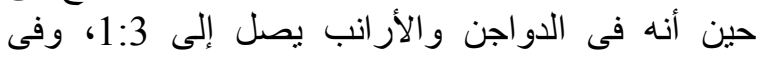

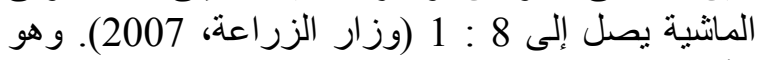

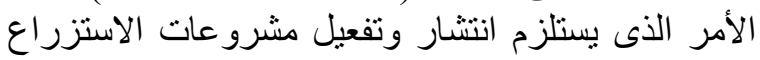

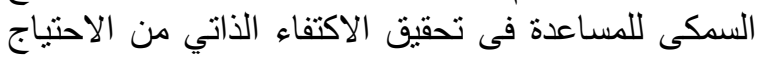

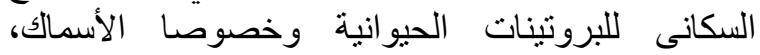

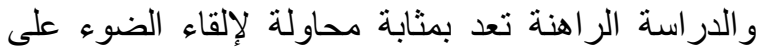

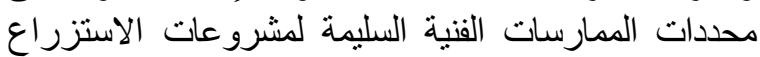

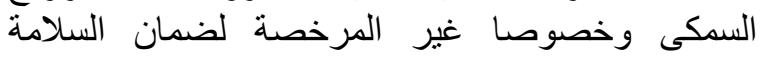

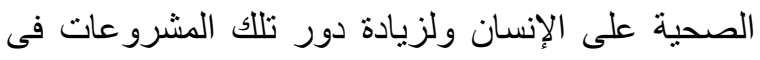

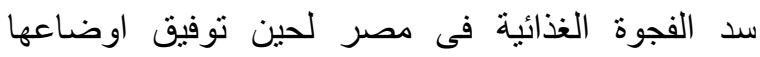
لتخضع للرقابة الحكومية وتصبح مرخدة.

\section{المشكلة البحثية للاراسة}

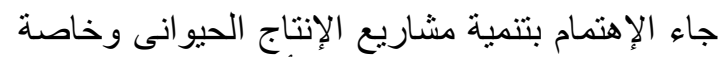

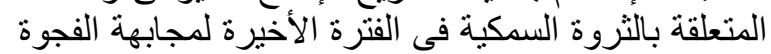
الغذائية الناتجة عن نقص البروتينات الحيوانية اللازمة 
يقل عن 2.1 متر، عرض الجسور الرئيسية والفرعية لا

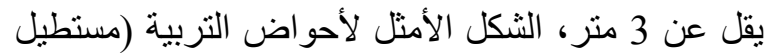
- دربع)، الانحدار الأمثل لقاع الأن لأحوض (بدرجة 120

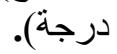

\section{ممارسات خاصة بالتحضين}

وتتمثل فى المو اصفات المثلى للحضانة (نظيفة ، خالية التهنية

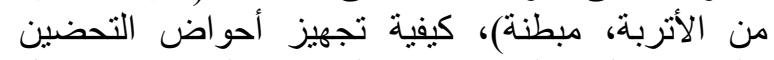

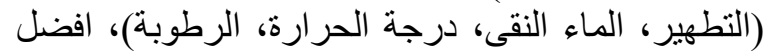

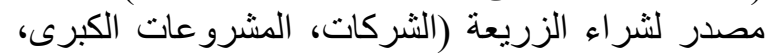

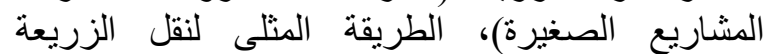
(تانكات، براميل، أكياس)، الطريقة المثلى لأقلمة الزريعة الزئلة (مر اعاة فروق حرارة، ربك، رطوبة).

\section{ممارسات خاصة بالتربية}

وتتمثل فى المساحة المتلى لحوض التربية من (1-2)

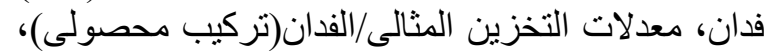

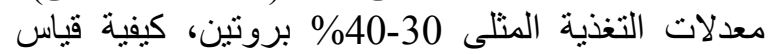

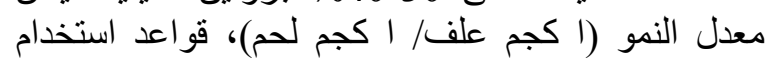
العلائق 30\% بروتين للعليقة المطبوخة.

\section{ممارسات خاصة بإدارة المياه}

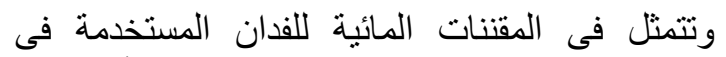

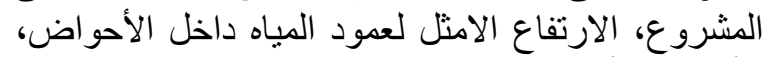

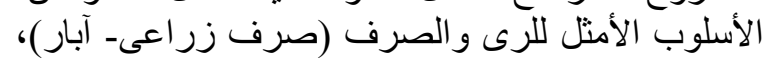

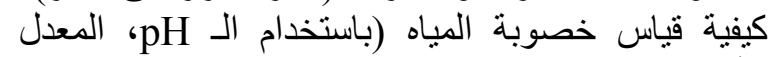
الأمثل لتغيير المياه يوميا من (6-9) ساعات.

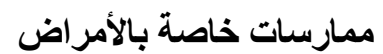

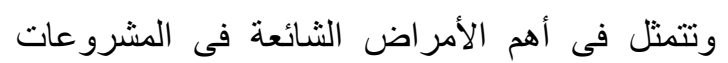

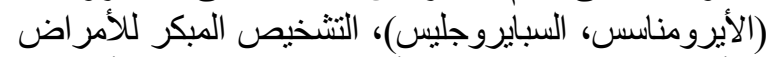

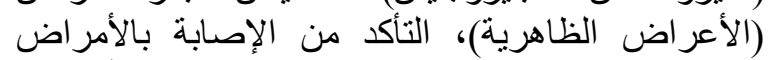

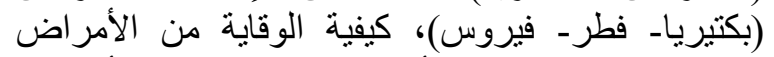

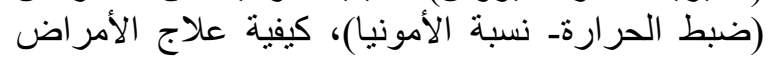

(وصف الجر عات الدوائية المناسبة).

\section{ممارسات خاصة بالحصاد}

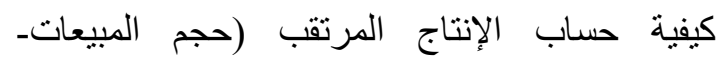

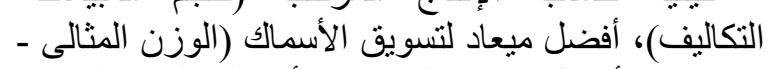

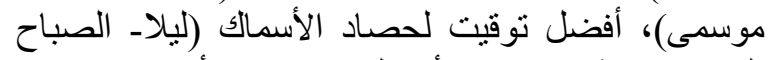

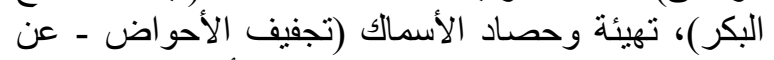

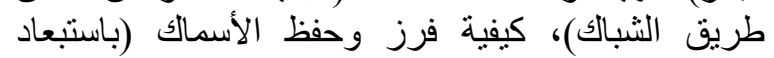

$$
\text { المريض - الضعيف). }
$$

\section{النظريات المفسرة للسلوك والممارسات البشرية}

من النظريات العديدة التى يمكن أن تستفيد منها

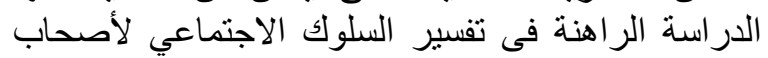

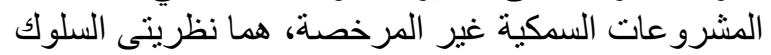

الإطار النظرى والدراسات السابقة

مفهوم الاستزراع السمكى، أنواعه، وممارساته القنية

السليمة

$$
\text { مفهوم الاستزراع السمكى }
$$

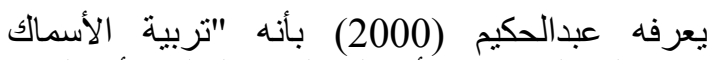
بأنواعها المختلفة سواء أسماك المباه المباه المالحة أو العذبة العذبة

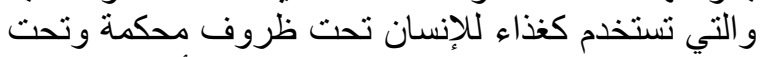

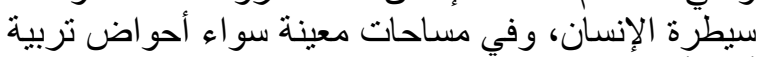
أو أقفاص، بلإنسان وفي تطوير الإنتاج وتثبيت ملكية

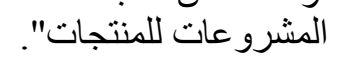

$$
\text { أنواع المشروعات السمكية }
$$

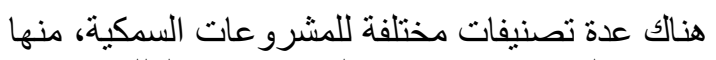

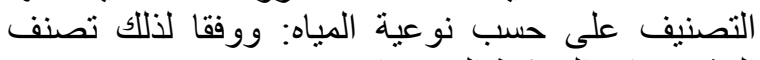

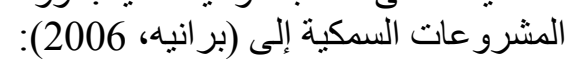

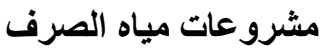

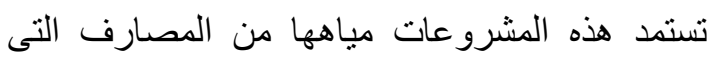

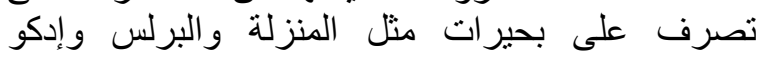
ومريوط، لذا تنتشر هذه المشرو عات بجانب بحير ات نهاية الرى .

\section{مشروعات المياه العذبة}

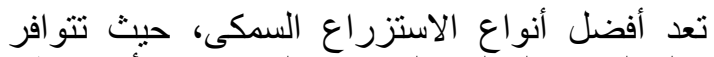

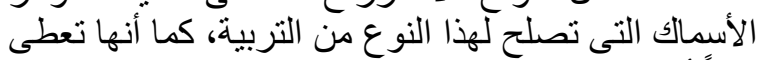
نمواً أفضل.

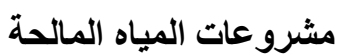

ينتشر هذا النوع من المشروعات على ساحل البحر

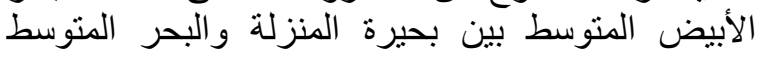

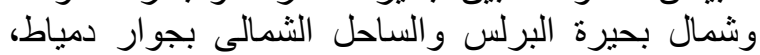

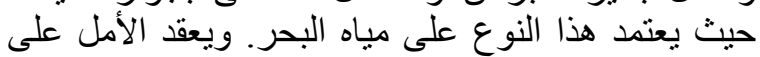

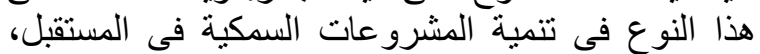

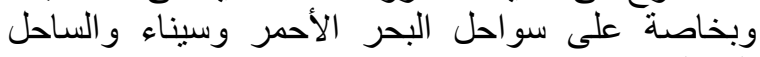

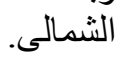
مشروعات المياه الشروب و المياه الثروب هى خليط من المياه المالحة و العذبة، ويننشر هذا النوع من المشروعات هليط في المناطق الثمالية الثرالية

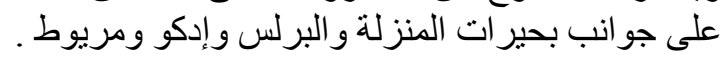
الممارسات الفنية السليمة لمشروعات الاستزراع السمكى تعتمد عملية الاستزراع السمكي على ستة ركائز أساسية هى (صلاح، 1991).

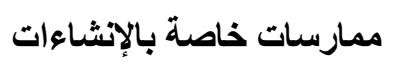

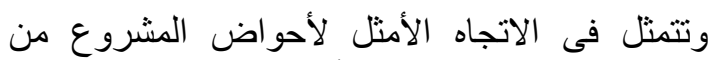

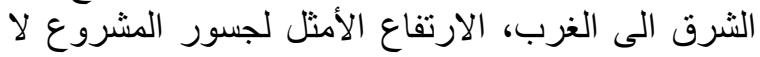




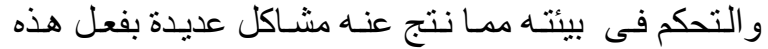

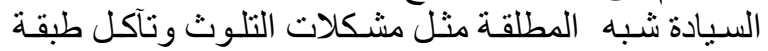

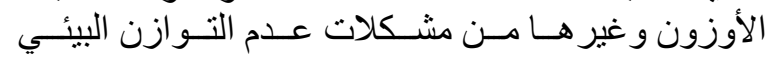

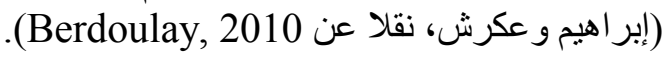

الار اسات السابقة

من الدراسات العديدة و الهامة التى يمكن أن تستفيد منها

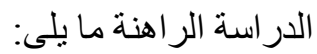

در اسة يوسف (2009) بعنوان "مشكلات الاستزراع المكاع

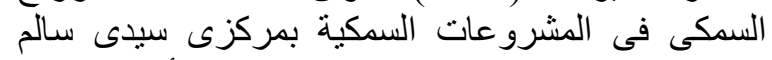

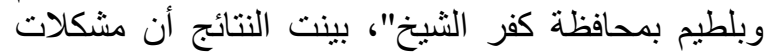

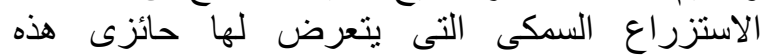

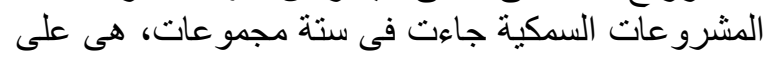

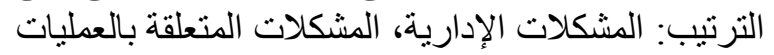

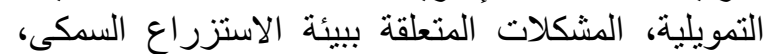

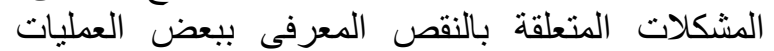

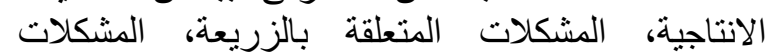

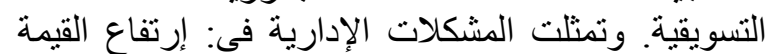

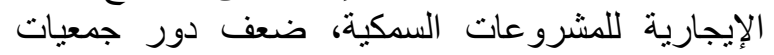

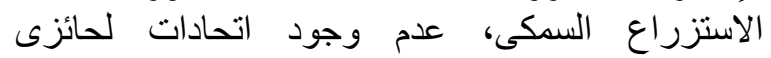

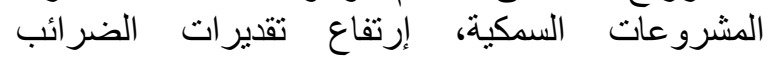

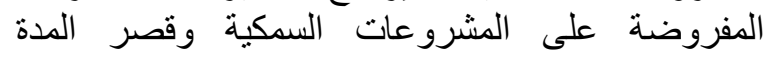
الإيجارية للمزراع السمكية المؤجرة من الثروة الثروة السمكية.

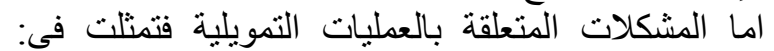

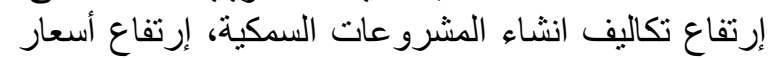

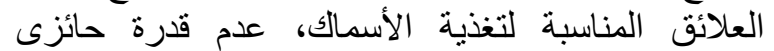
المشروعات السمكية على التمويل الذاتى لإجراء الأهية عملية

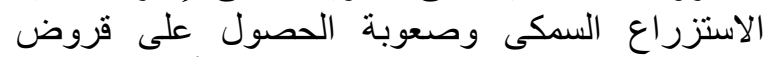
للاستثمار فى الاستزراع الاعنى السمكى. وكانت أهم المشكلات

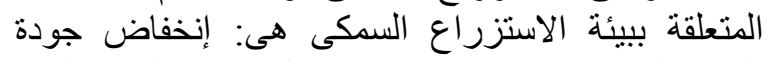

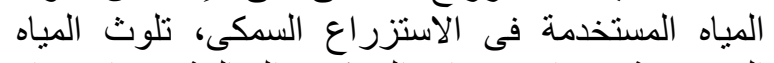

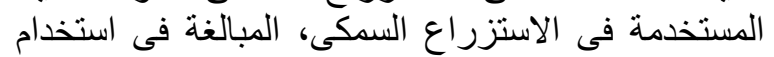

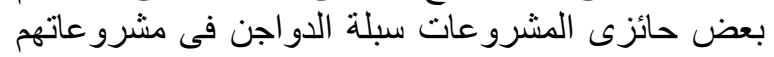

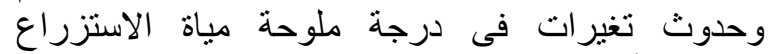

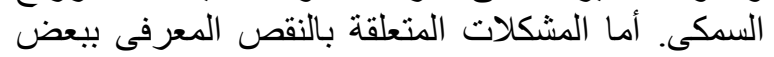

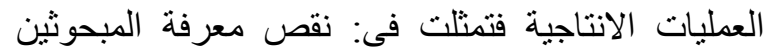

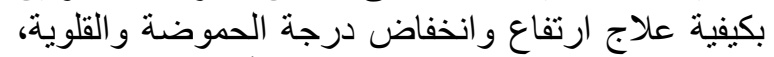
نقص المعرفة بكيفية علاج ارتفاع الخفاع أو إنخفاض نسية نسبة

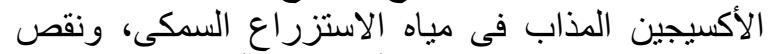

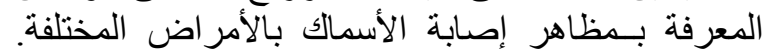

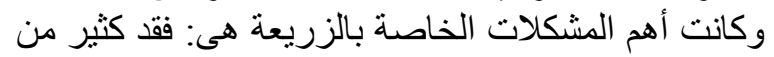

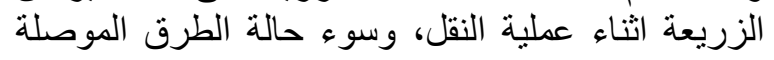

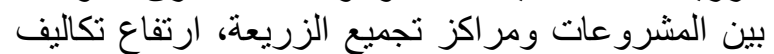

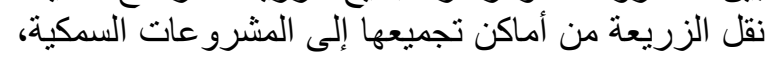

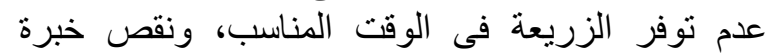

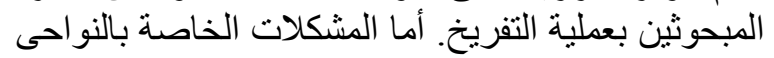
التسويقية فتمثلت فى: إحتكار بعض التين التجار للإنتاج
المخطط والإمكانية أو الاختيارية وفيما يلى عرض لئ مختصر لكل منهما:

\section{نظرية السلوك المخطط Planned behavior theory}

Fielding et al., Karami أوضح عكرش نقلا عن انهوك (and)

Ajzen and أن (and Mansoorabad, 2012)

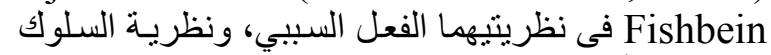

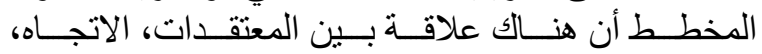

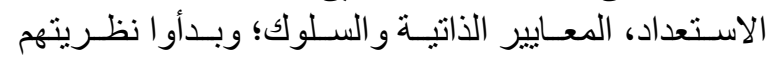

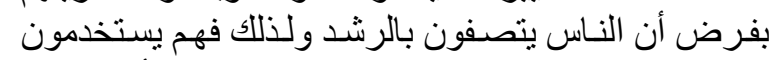

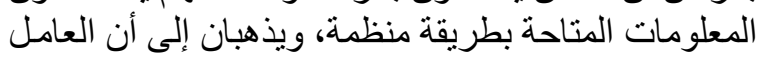

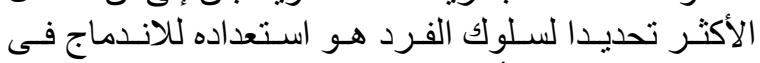

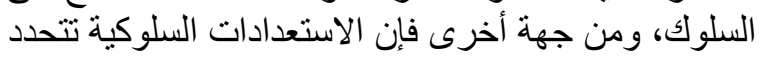

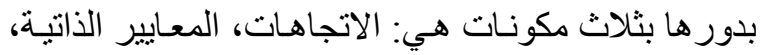

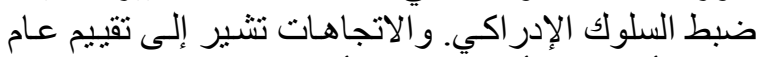

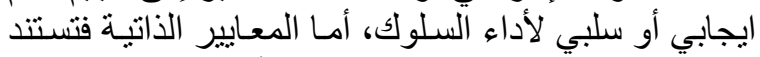

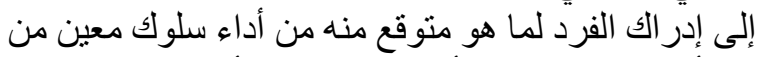

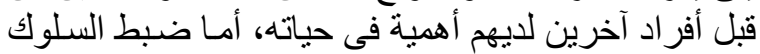

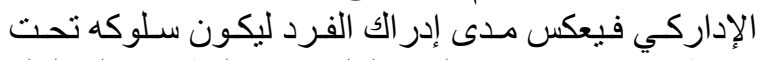

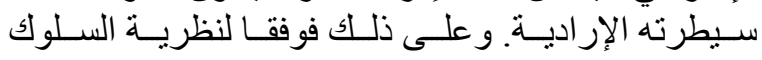

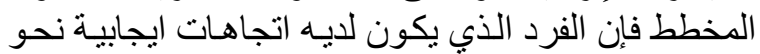

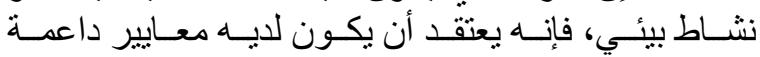

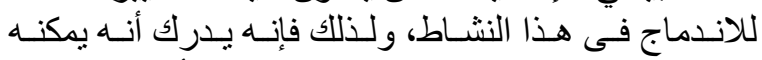

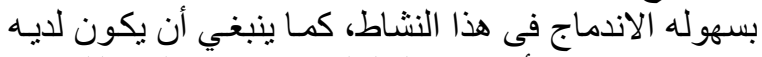

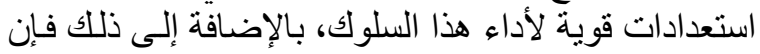

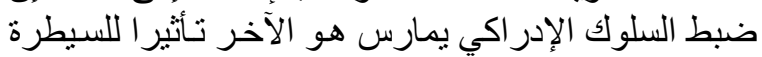

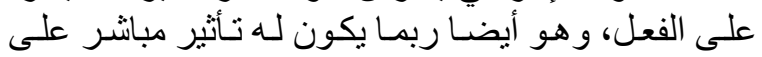

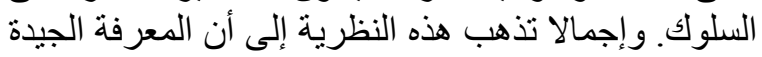

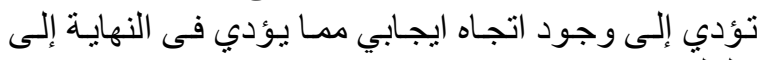
سلوك إيجابي. - وني

\section{Possibilism نظرية الامكانية أو الاختيارية}

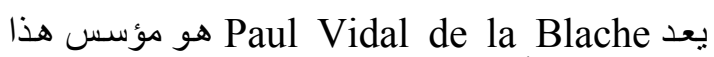

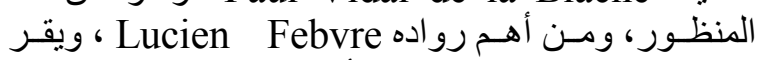

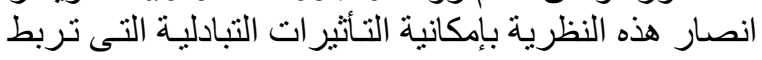

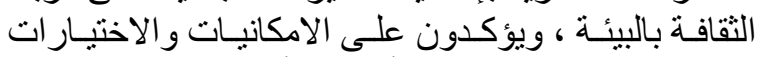

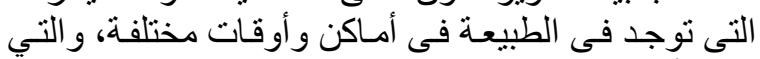

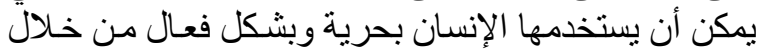

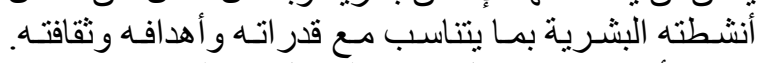

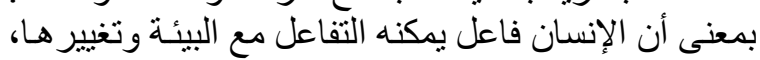

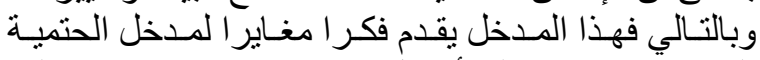

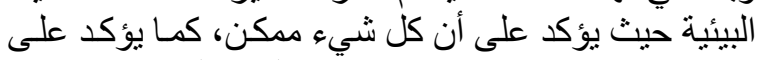

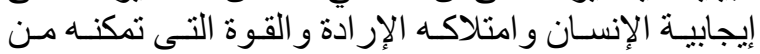

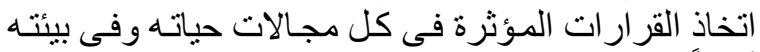

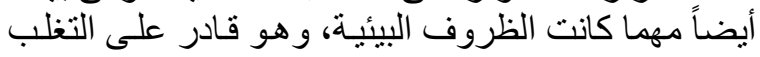

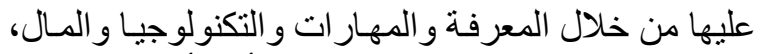

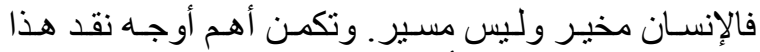

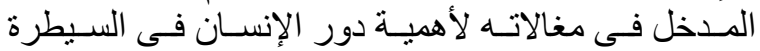




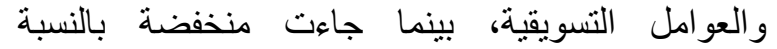
للإمكانيات المادية و علاقة المشروع بالمنظمات الماتهات المحلية،

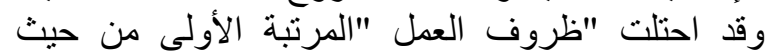
درجة رضا المبحوثين عن الظروف الطئ الانتاجية بنسبة الإلية

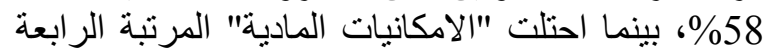

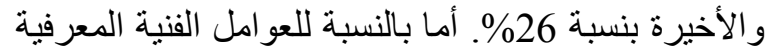
والتطبيقية: تبين وجود انخفاض فى المستية المستوى المعرفى

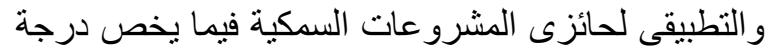

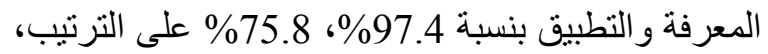
فى حين احتلت درجة المعرفة والتطبيق بالأمراض

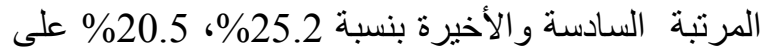

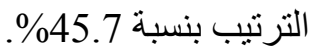

\section{الفروض البحثية للار اسة}

1- نوجد علاقة معنويـة بين كل من المتغيـر ات المستقلة

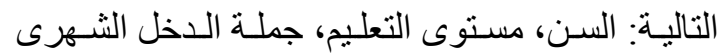

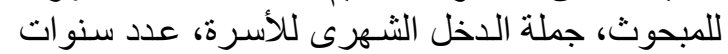

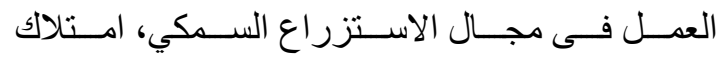

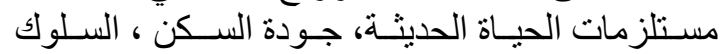

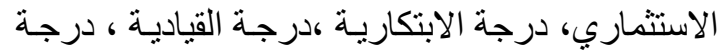

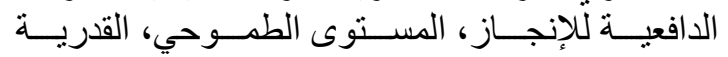

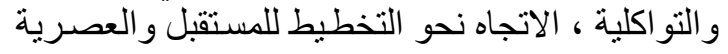

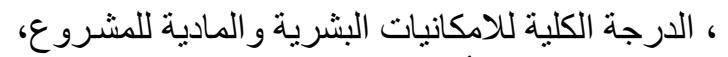

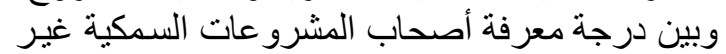

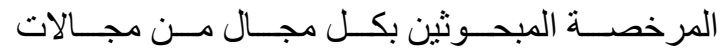

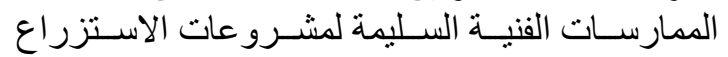

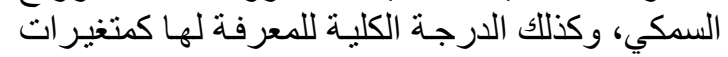

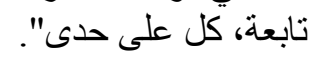

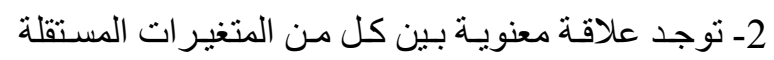

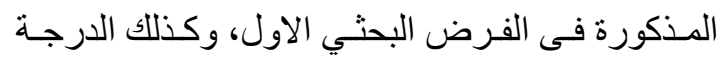

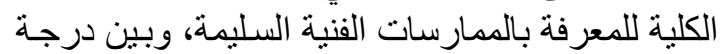

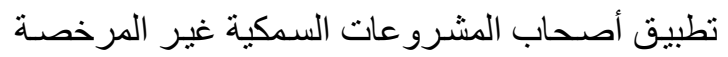

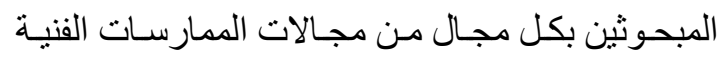

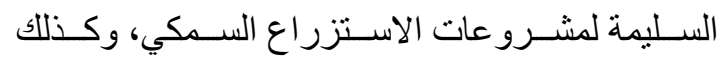

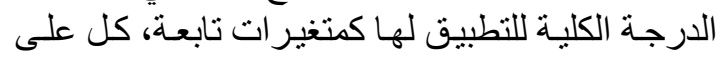
حدى.

3- توجد علاقة معنوية بين المتغير ات المستقلة المدروسـة

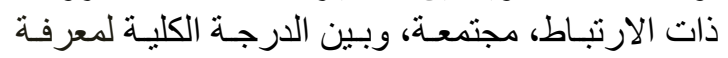

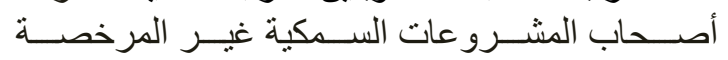
المبحوثين بالممارسات الفنية السليمة كمتغير تابع.

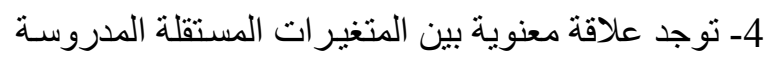

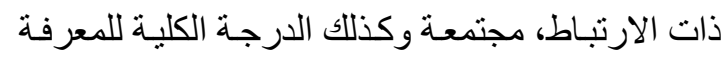

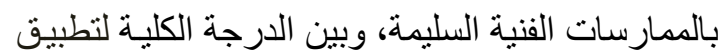

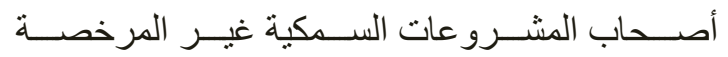
المبحوثين للممارسات الفنية السليمة كمتغير تابع.
السمكى، إنخفاض أسعار تسويق الأسماك، عدم توفر

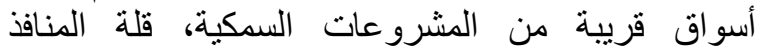
التسويقية، قلة المعلومات المتوفرة عن تسوية المنيق الأسماك

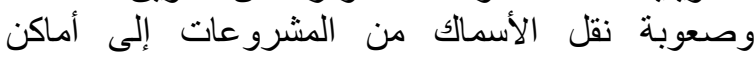
التسويق. وتبين أن أهم الدصادر الاتصالية التى يلجأ إليها

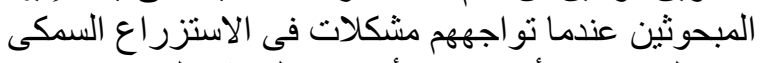
هى: الجيران، الأصدقاء، الأقارب و المرشد الزين الزراعي.

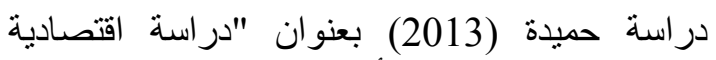

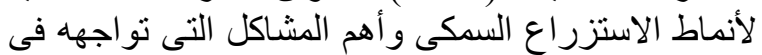

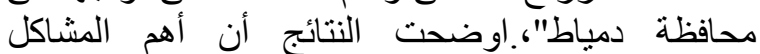

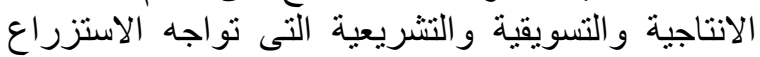

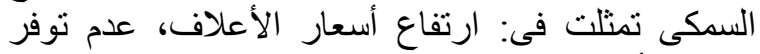

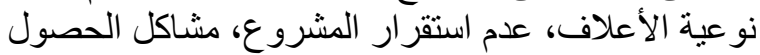

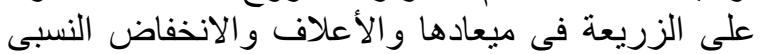
فى أسعار الأسماك، على التى فيعاديب.

دراسة زهران (2014) بعنوان "محددات تلتمية الاستية الاستزراع السمكى البحرى فى منطقة المثلث بمحافظة

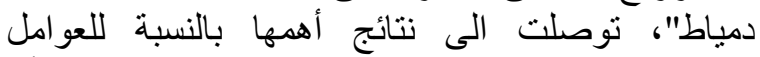

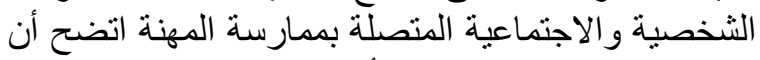

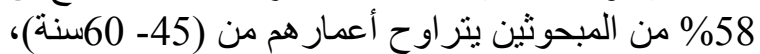

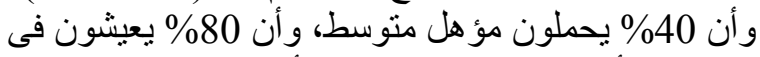

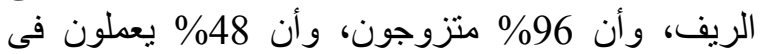

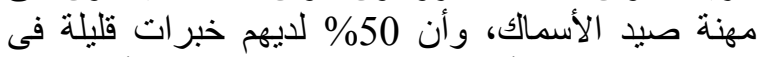

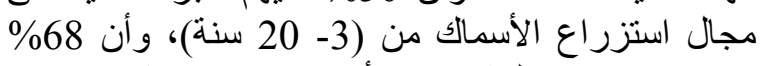

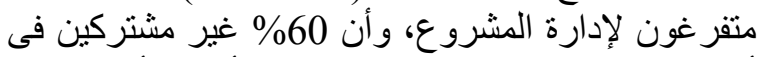

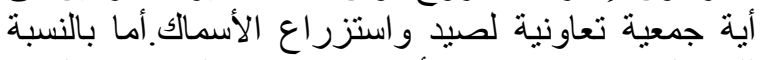

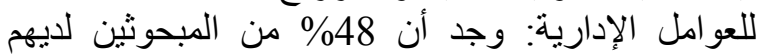

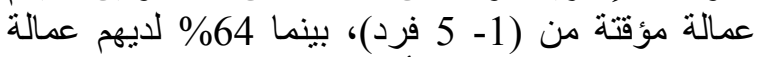

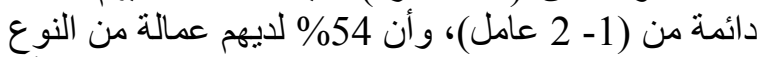

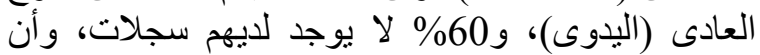

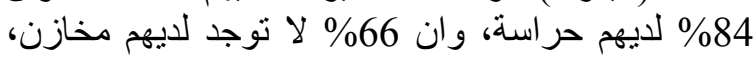

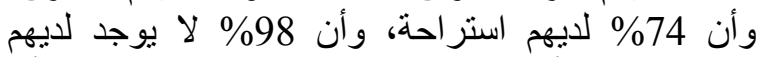

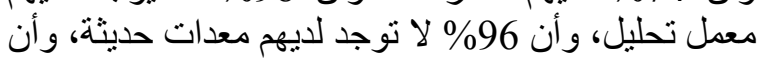

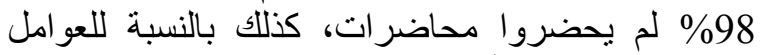

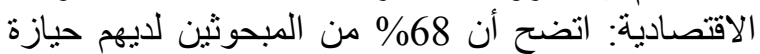

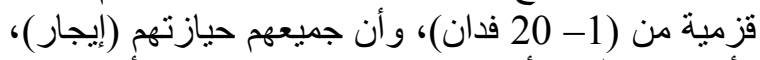

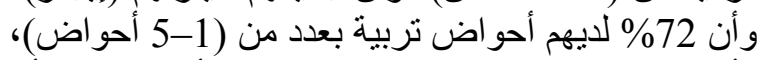

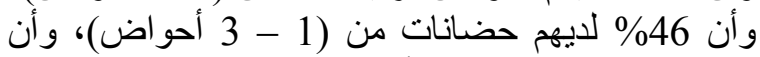

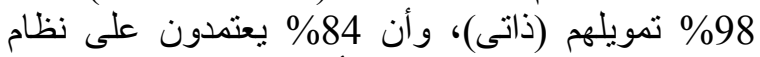

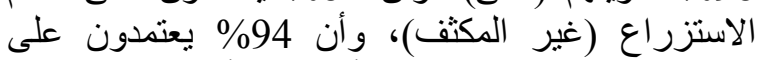

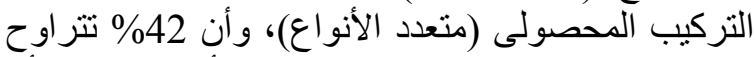

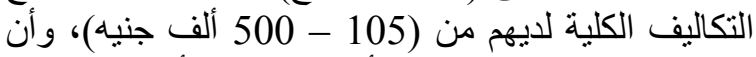

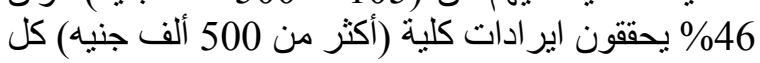

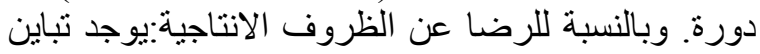

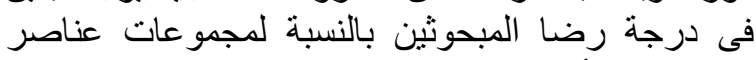
الرضا، إلا أنها جاءت منوسطة بالنسبة لظروف لئن العمل 
حسب كرقم مطلق بعدد سنوات عمر المبحوث حتى وقت إجر اء هذه الدر اسة.

\section{مستوى التعليم}

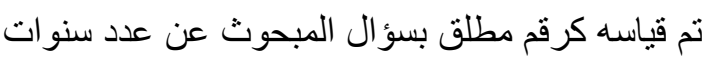

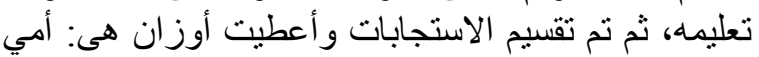

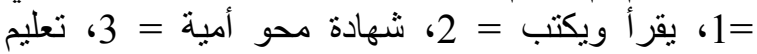

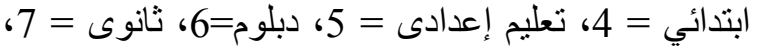

$$
\text { فوق منوسط =8، جامعى = } 9 .
$$

\section{الحالة الزواجية}

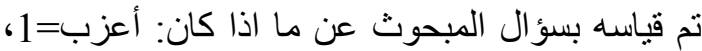
خاطب =2، منزوج=3 3، أرمل=4، أو مطلق=

\section{جملة الاخل الثهرى للمبحوث}

حسب كرقم مطلق بقيمة الدخل الثهرى للمبحوث.

\section{درجة كفاية الاخل للمعيشة}

تم قياسه بسؤال المبحوثين عن درجة كفاية الدخل

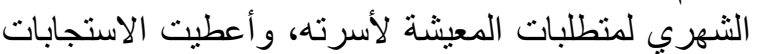

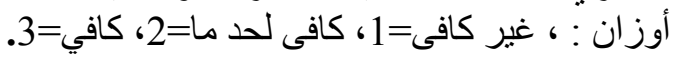

$$
\text { جملة الاخل الثهرى للأسرة }
$$

حسب كرقم مطلق بقيمة جملة الدخل الثهرى لاسرة

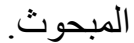

\section{جملة عدد أبناء الأسرة}

حسب كرقم مطلق بجملة عدد أبناء المبحوث.

\section{عدد الأبناء العاملين فى المشروع}

حسب كرقم مطلق بجملة عدد أبناء المبحوث الذين

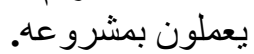

عدد أفراد الأسرة العاملين فى المشروع

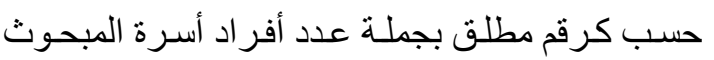

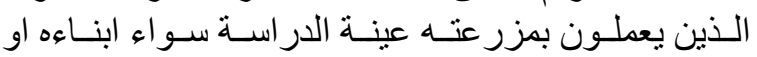

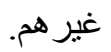

المستوى الاجتماعى و الاقتصادي للجيران

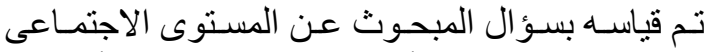

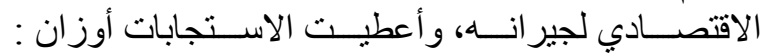
محدود=1، منوسط=2، راقي=3.

عدد سنوات العمل فى مجال الاستزراع السمكي تم قياسه كرقم مطلق بسؤال المبحوث عن عدد سنوات عمله فى مجال الاستزر اع السمكي.
اعتمدت الدر اسة الر اهنة على منهج المسح الاجتماعي

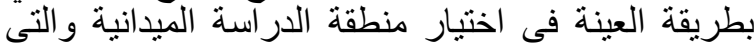
تحددت فى محافظة الثرقية، وذللك لعدة أسباب هي: الكية أنها من أكبر محافظات الجمهورية في عدد السكان حيثة حيثة تحتل المركز الثالث من بين محافظات الجمهورية، و والمركز

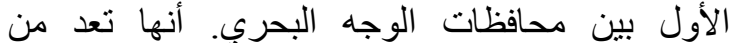

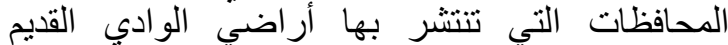

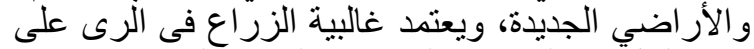

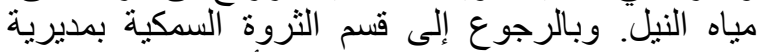

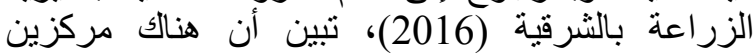

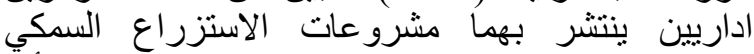

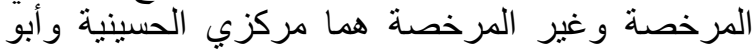

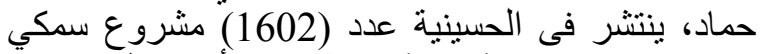

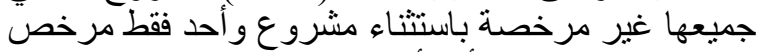

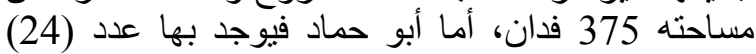

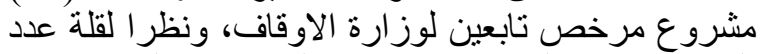

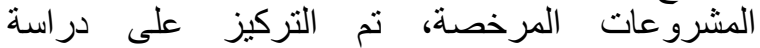

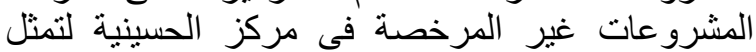

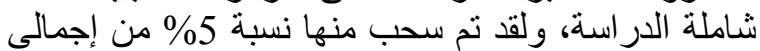

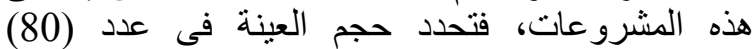

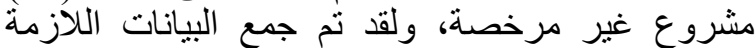
للار اسة بو اسطة أداة استمارة الاستبيان بالمقابلة الثخصية الثبانة مع أصحاب هذه المشرو عات، و الذين تم اختيار هم بطريقة المانة

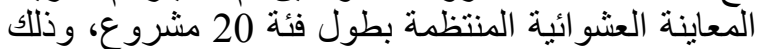

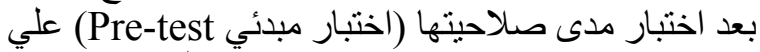

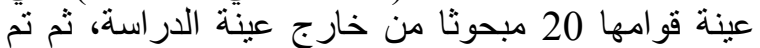
اجر اء بعض التعديلات على الاستمارة النهائية لتصبح فئح

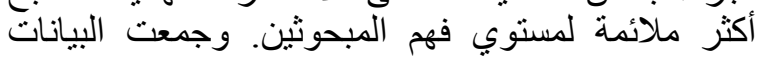

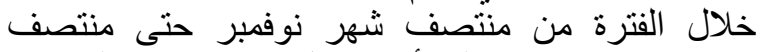

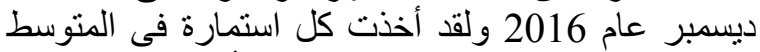

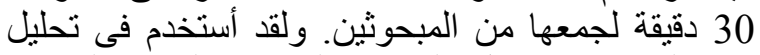

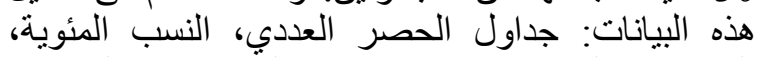

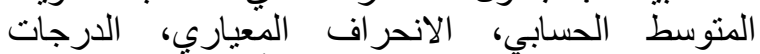

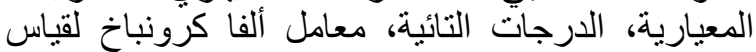

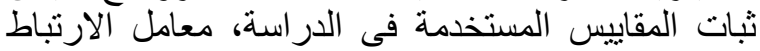

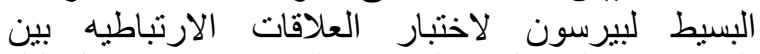

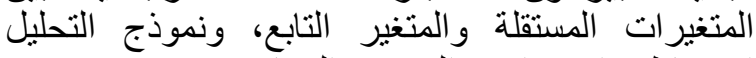

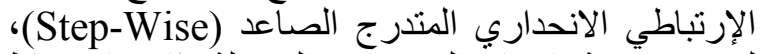

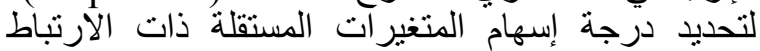
مجتمعة على المتغير التابع.

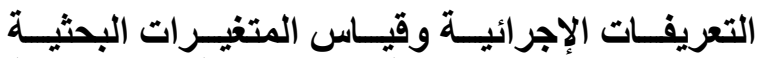

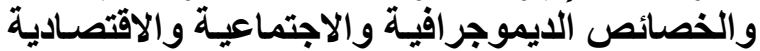

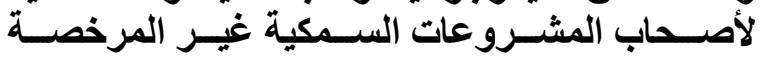
وامكانيات المشروعات المثروعات المتغيرات المستقلة النوع ويقصد به تحديد جنس المبحوث ما إذا كان ذكر ا أم أنتى. 
مصدر مياه الثرب

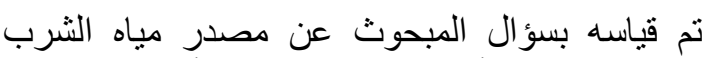

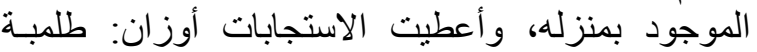

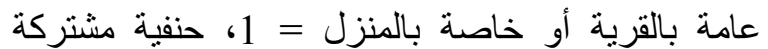
بالقرية =2، شبكة ميساه بالمنزل =المنزل

\section{نوع دورة المياه}

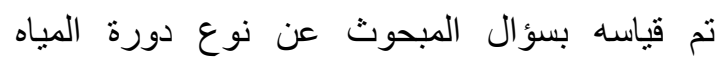

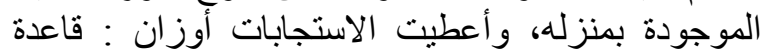

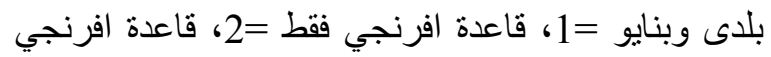
وبانيو =3.

\section{وسيلة الطبيخ}

تم قياسه بسؤال المبحوث عن وسيلة الطبيخ داخل

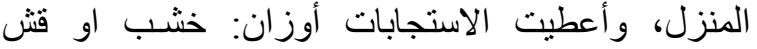
وحطب=1 ، موقد كيروسين=2، بوتاجـاز = 3.

الصرف الصحي

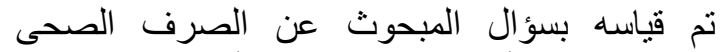

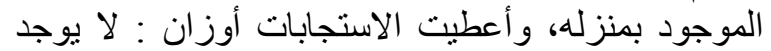

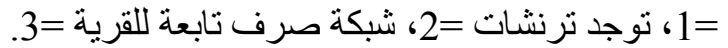

\section{نوعية المفروشات الموجودة بالمسكن}

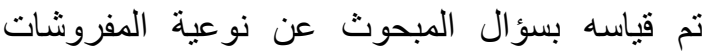
الموجودة بالمنزل، وأعطيت الاستجابات أوزان : تقليدية

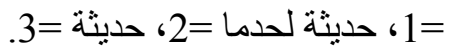

\section{نوعيـة طلاء المسكن}

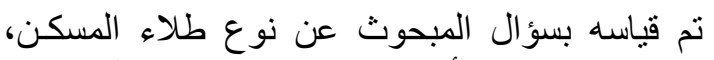

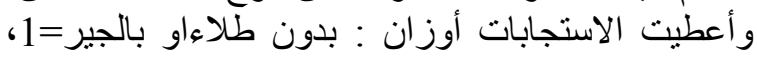
بالبلاستك =2، بالزيت الابت =

\section{المفروشات الموجودة بالمسكن}

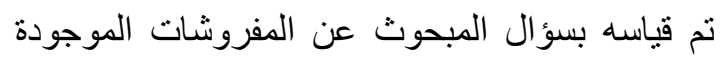

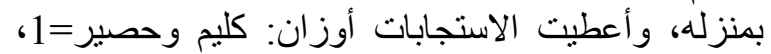
موكيث =2، سجاد =3ن.

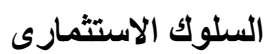

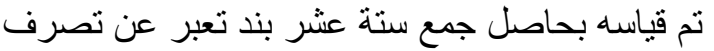

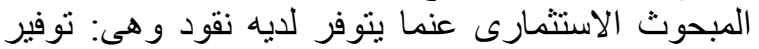

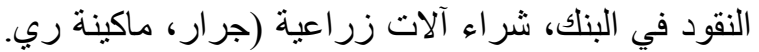

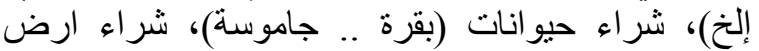

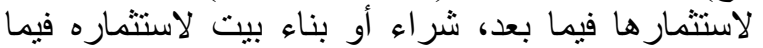

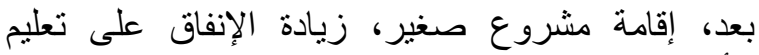

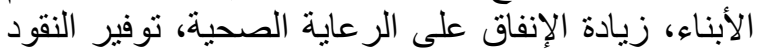

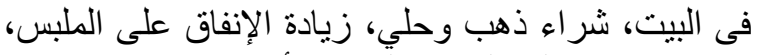

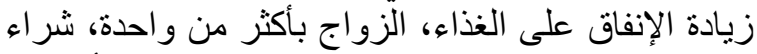
آلات كمالية و الإنفاق على المكيفات و المخدر اتل، واتئ وأعطيت
التفرغ لإدارة المشروع

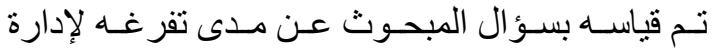

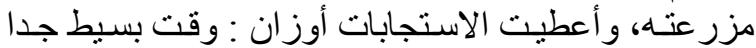

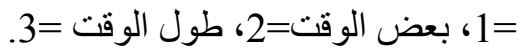

امتلاك مستلزمات الحياة الحليثة

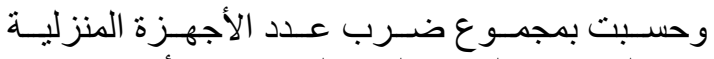

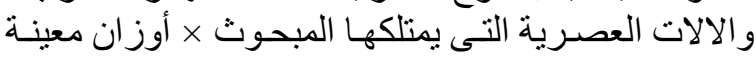

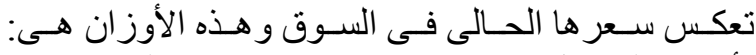

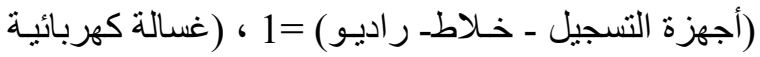

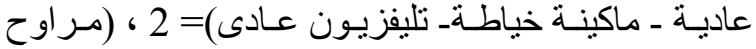

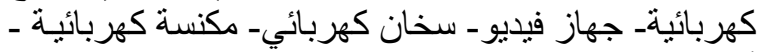

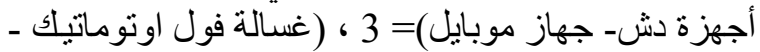

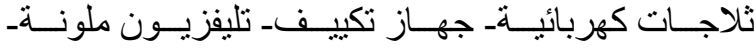
بوتاجاز ات -جهاز كمبيوتر)= 4.

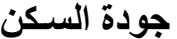

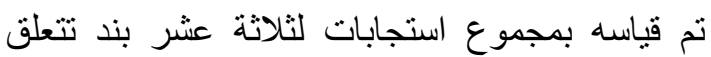
بالمنزل الذي يقيم فيه هو و اسرته وهي :

\section{نوع ملكية المنزل الائم}

نم قياسه بسؤال المبحوث عن نوع ملكية المنزل الدائم

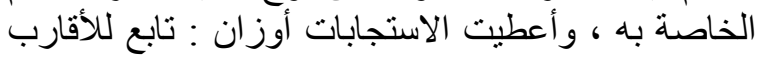
1= إيجار =2، ملك =

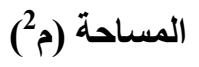

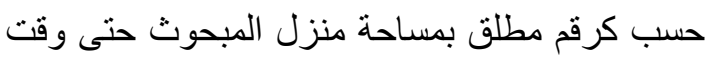

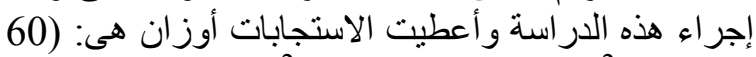

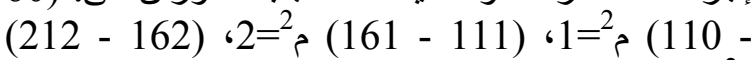
$.3={ }^{2}$ r

\section{عدو طوابق المنزل}

حسب كرقم مطلق بجملة عدد طو ابق المنزل الخاصة

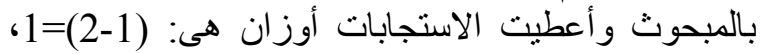

$$
\text { . } 3=(6-5) ،(4-3)
$$

\section{عدد الغرف بخلاف الحمام والمطبخ}

حسب كرقم مطلق بجملة عدد الغرف بخلاف الحمام و المطبخ و الموجودة بمنزل المبحوث و وأعطيت الاستجابات

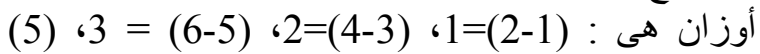

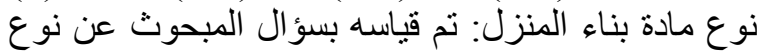

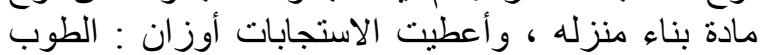

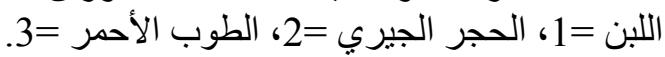

$$
\text { أرضيـة المنزل }
$$

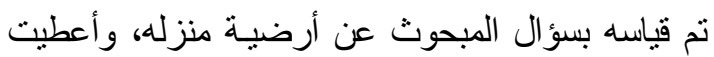

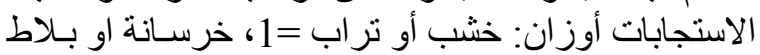
2، سبر اميك =3 الابك ان. 
شايف إن مستقبلى هيكون أفضل من الحاضر، و وانا مقتنع

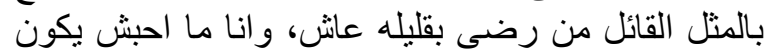

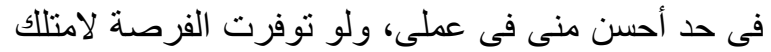

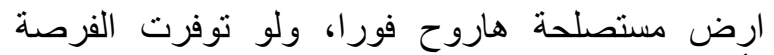

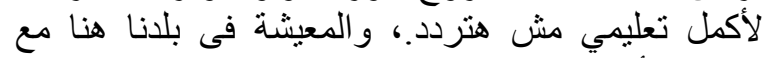

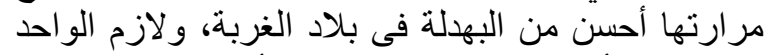

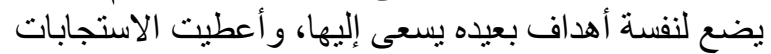

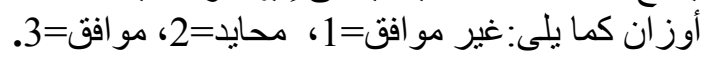

\section{القدرية والتوكلية}

تم قياسه بمجمو ع الاستجابة على تسع عبار ات اتجاهية

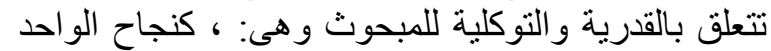

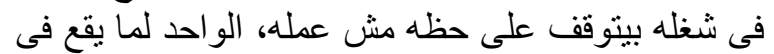

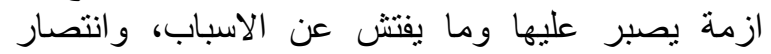

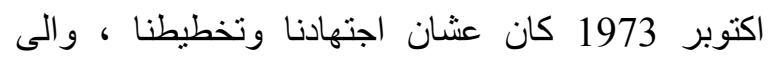

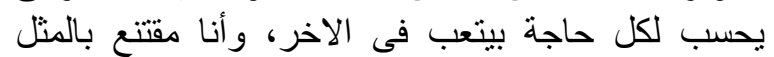

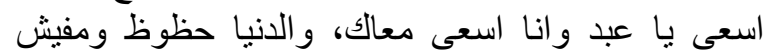

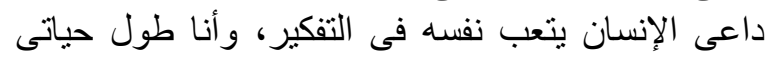

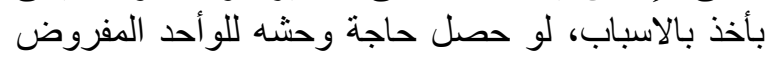

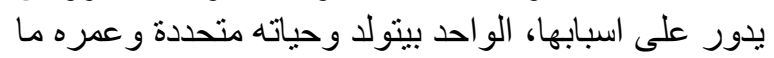

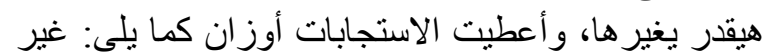

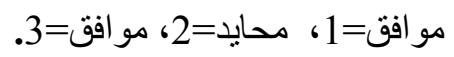

\section{الاتجاه نحو التخطيط للمستقبل و العصرية}

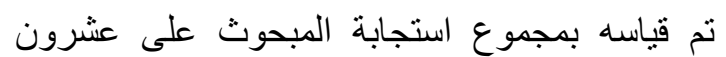

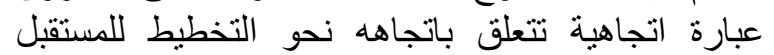

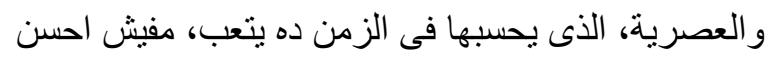

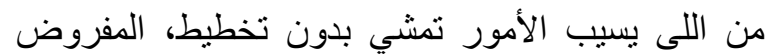
الإنسان يخطط لبكره علثان ينجح فى شغله الأله، الو احد لازم يحكم عقله فى كل حاجة يعملها، الناس اللى بلى بيخططوا

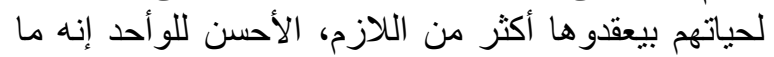

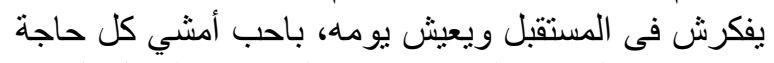

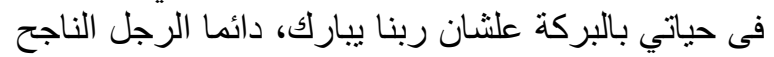

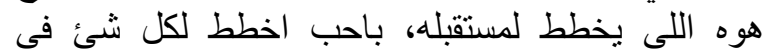

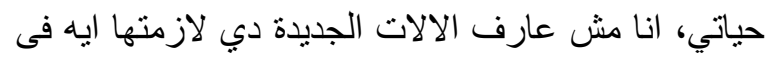

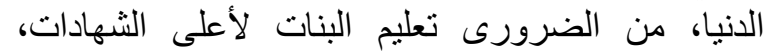

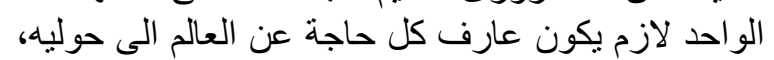

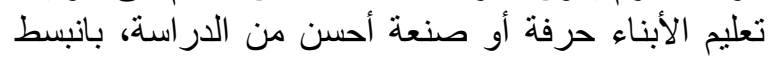

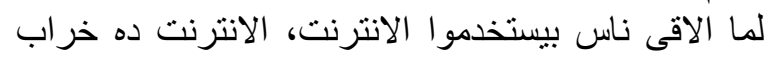

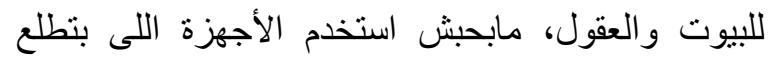

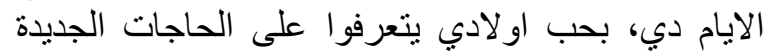

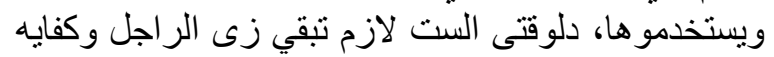

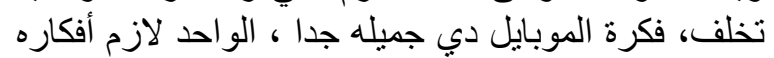

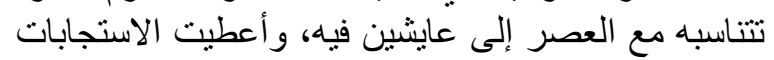

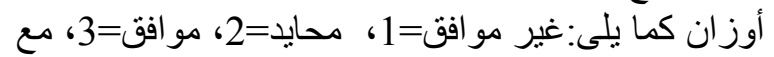
عكس هذه الأوزان في حالة العبار ات السلبية.
الاستجابات أوزان كما يلى: لا=1، نادر = = 2 ، أحيانا =

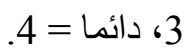

درجة الابتكارية

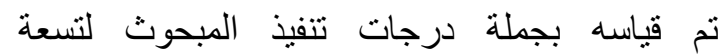

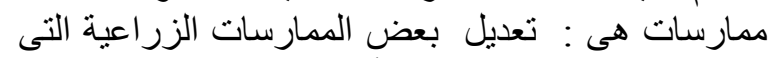

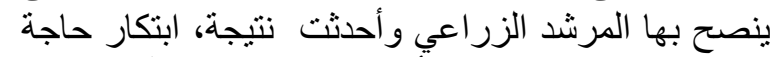

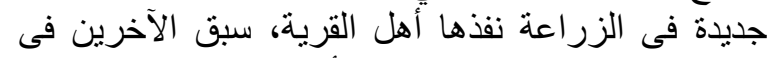

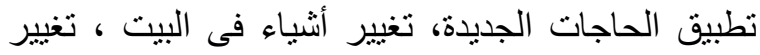

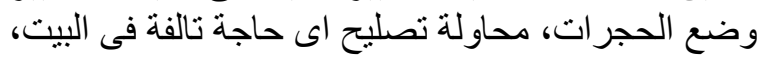

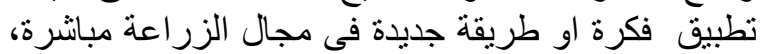

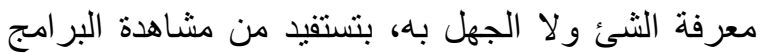

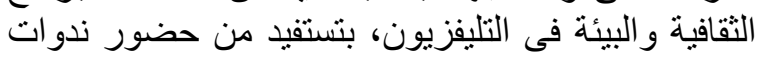

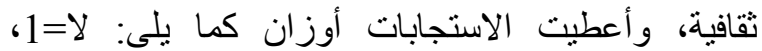
نادر =|2، أحيانا=3، دائما=4.

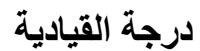

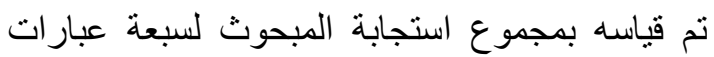

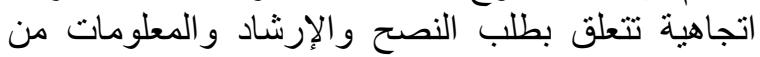

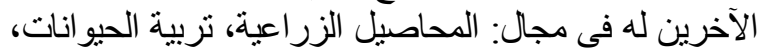

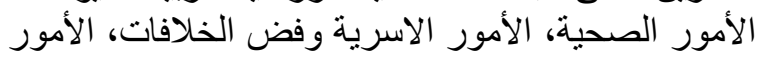

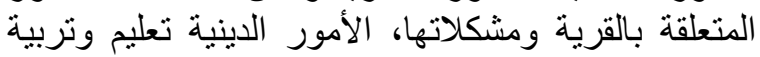

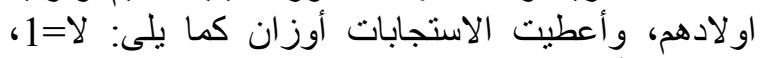

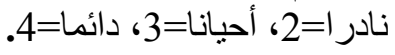

\section{درجة الدافعية للإنجاز}

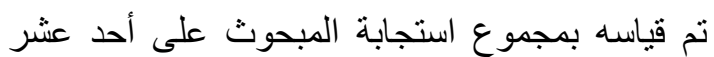

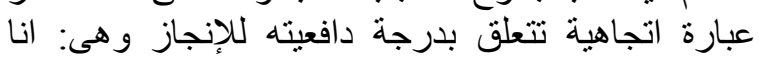

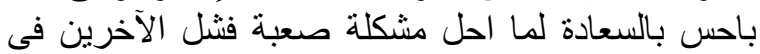

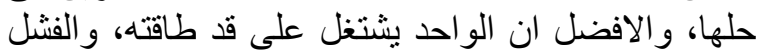

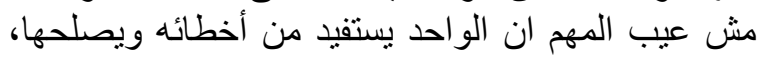

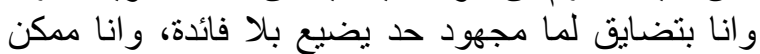

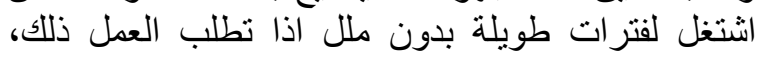

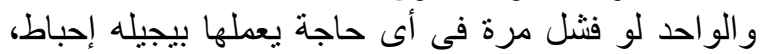

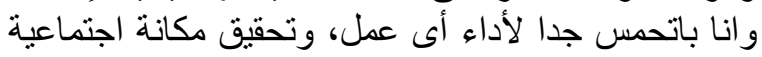

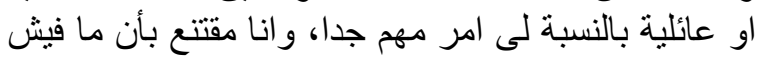

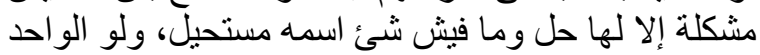

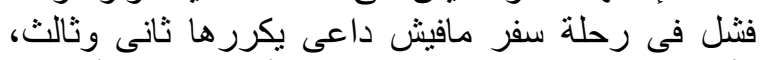

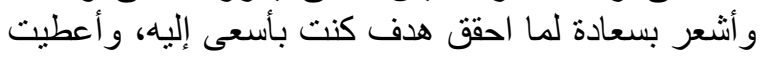

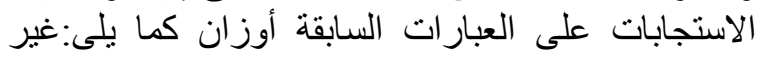

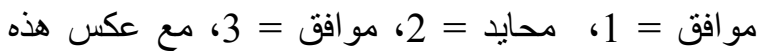
الأوزان فى حالة العبار ات السلبية.

\section{المستوى الطموحي}

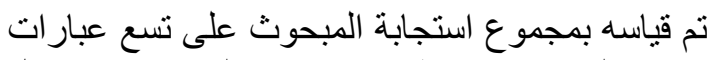

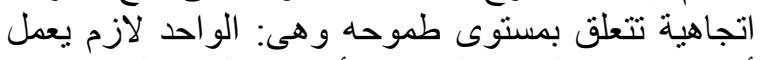

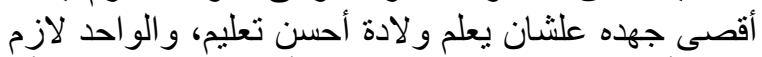

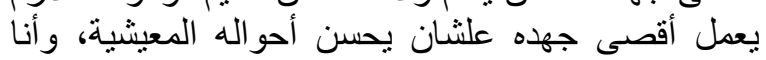




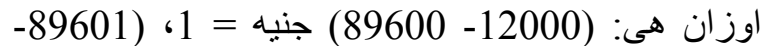

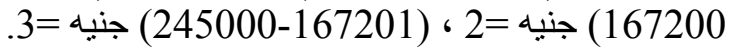

\section{التكاليف المتغيرة للمشروع}

حسب كرقم مطلق بسؤال المبحوث عن التكاليف المتغيرة لمشرو عهد ونم تقسيم الاستجابات الى ثثلاث فئات الثئ

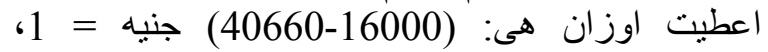
(65321 - 40661) جنيه = 2، (6000-65322) جنيه

$$
.3=
$$

درجة كفاية التمويل

تم قياسه بسؤال المبحوث عن درجة التهوبة كفاية التمويل

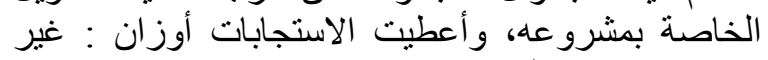

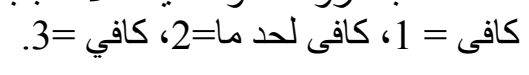

نظام الاستزراع

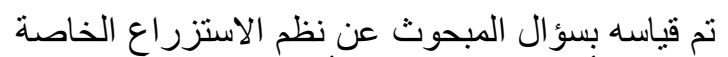

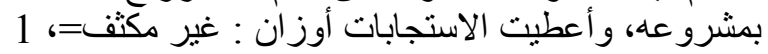
نصف مكثن =2، مكثنف = 3 =

$$
\text { الأرباح الكلية للمشروع فى الموسم }
$$

حسب كرقم مطلق بسؤ ال المبحوث عن الأرباح الكلية

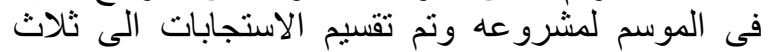

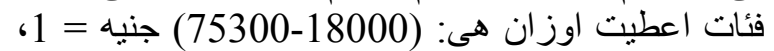

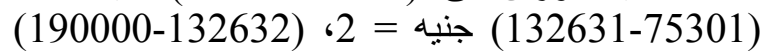

$$
\text { جنيه = } 3
$$

\section{مدى توفر الحراسة}

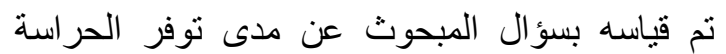

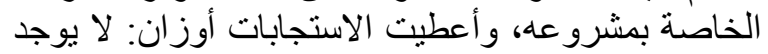

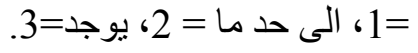

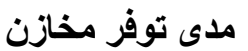

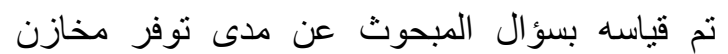

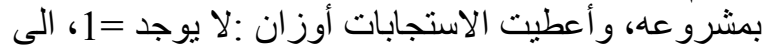

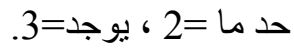

\section{مدى توفر استراحة بالمشروع}

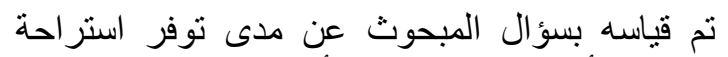

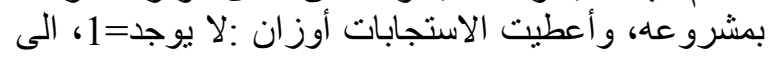

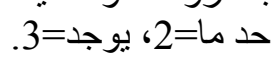

\section{مدى توفر معمل تحليل بالمشروع}

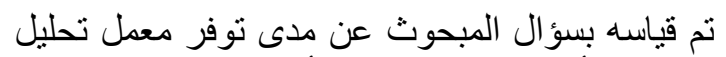

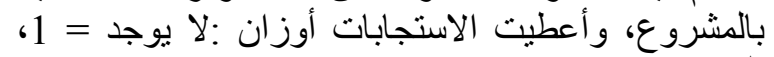

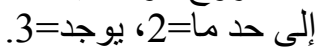

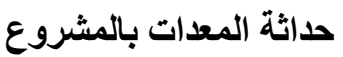

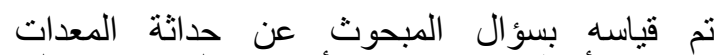
بالمشروع، وأعطيت الاستجابات أوز ان: تقليدية = 1، الى الى حذ ما = 2، حديثة = 3.
الارجة الكلية للامكانيات البشرية والمادية لمشروعات

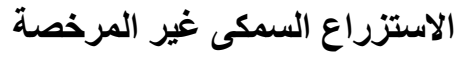

تم قياسه بمجموع استجابة المبحوث لثمانية عشر بند وهى:

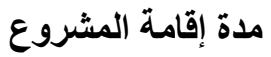

حسب كرقم مطلق بعدد سنوات إقامة المشروع وتم المقات

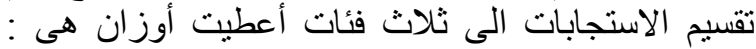

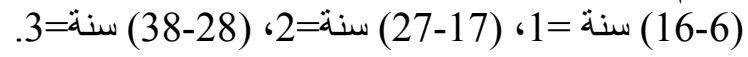

عدد العمالة المؤقتة

حسب كرقم مطلق بسؤال المبحوث عن عدد العمالة المؤقتة العاملين بمشرو عهد وتم تقسيم الاستجابات الى الى ثناث

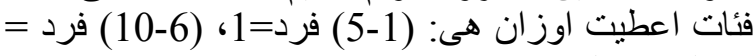

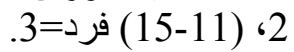

عدد العمالة الدائمة

حسب كرقم مطلق بسؤال المبحوث عن عدئ العمد العمالة

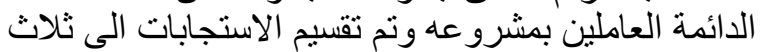

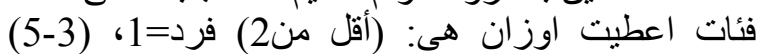

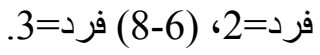

\section{حجم المساحة المقام عليه المشروع}

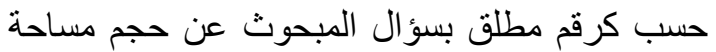

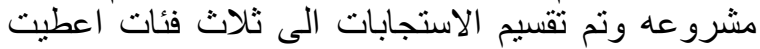
اوزان هى: (8-20) فدان=1، (21-33) فدان=2، فئن (34-

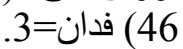

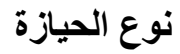

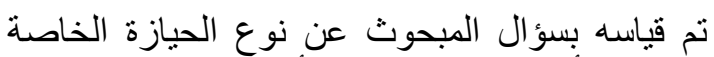

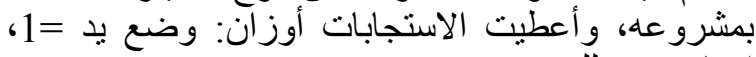
إيجار =2، ملك= 3.

$$
\text { عدد أحواض التربية }
$$

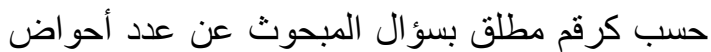

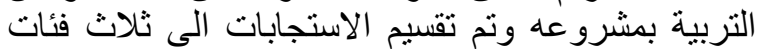

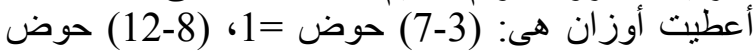

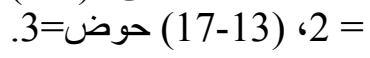$$
\text { عدد أحواض الحضانات }
$$

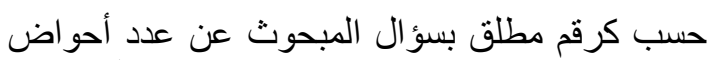
الحضانات بمشرو عاته وتم تقسيم الاستجابات الى الى ثلاث

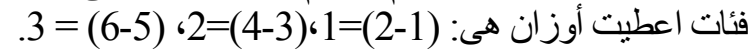

\section{نوع التمويل}

تم قياسه بسؤال المبحوث عن نوع التون التمويل الخاص بمشرو عه، وأعطيت الاستجابات أوزان : تجار سمك =ل =1، قروض=2، ذاتى=3.

\section{التكاليف الثابتة للمشروع داتي}

حسب كرقم مطلق بسؤال المبحوث عن التكاليف الثابتة

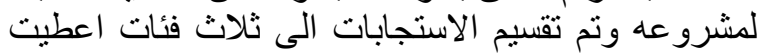


باستخدام ال pH، المعدل الأمثل لتغيير المياه يوميا من

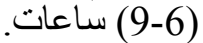

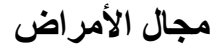

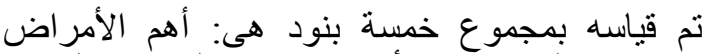

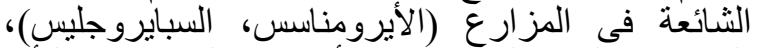

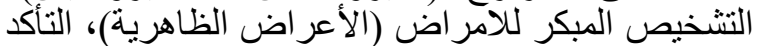

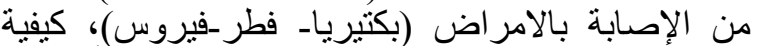
الوقاية من الامر اض (ضبط الحرارة الاضية نسبة الأمونبا)، كيفية علاج الامر اض (وصف الجراضية الجرعات الدو ائية المناسبة.

\section{مجال الحصاد}

تم قياسه بمجموع خمسة بنود هى: كيفية حساب الإنتاج

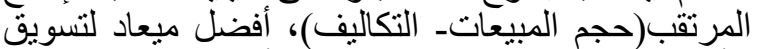

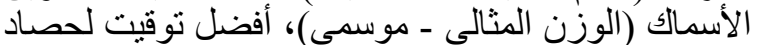

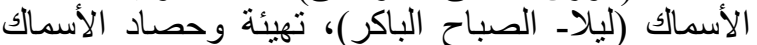

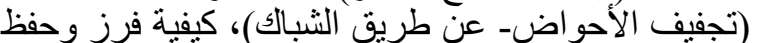

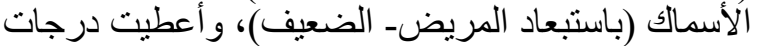

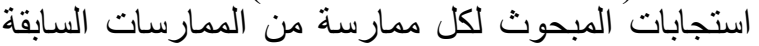

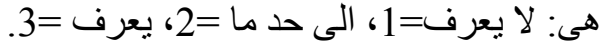

الارجة الكلية لتطبيق اصحاب مشروعات الاستزراع السمكى غير المرخصة التطبق

تم قياسها بمجموع الدرجات التائية لنطبيق المبحوث

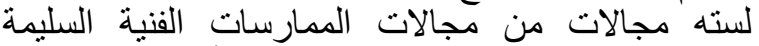

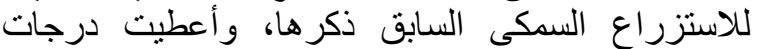

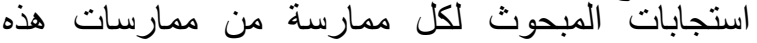

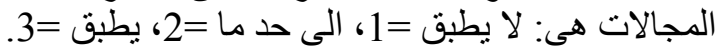
درجة صدق وثبات المقاييس المستخدمة في الدراسة لاختبار درجة صدق وثبات المقاييس المستخدمة في

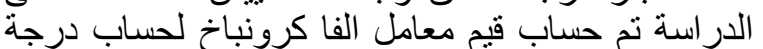

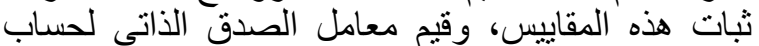

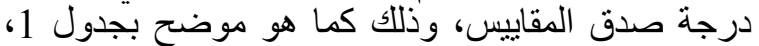

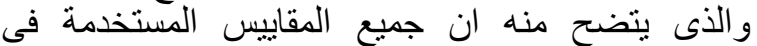

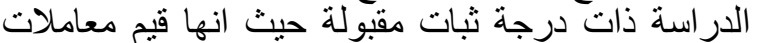
الفا كرونباخ أعلى من 0.6 ، كما انها ذات درجة دئ صدق

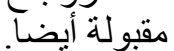

المتغيرات التابعة

الارجة الكلية لمعرفة اصحاب مشروعات الاستزراع المئية السمكي غيز المرخصة المرفة بالممارسات مشرات الفنية السليمة

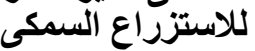

تم قياسها بمجموع الدرجات التائية لمعرفه المبحوث بسته مجالات من مجالات بمدات الممارسات الفنية السليمة

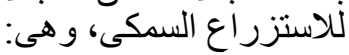

مجال الإنشاءات

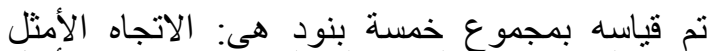
لأحو اض المزر عة من الثرق الى الغرب، الارتفاع الأمثل

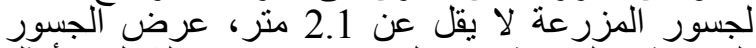

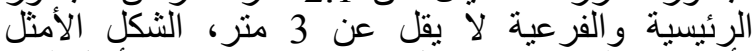
لأحو اض التربية (مستطيل- مربع)، الانحدار الأمثل لقاع الأل الحوض (بدرجة 120 درجة).

مجال التحضين (بن

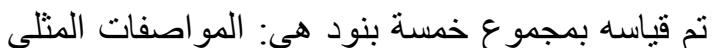

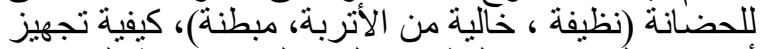

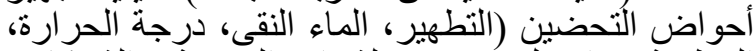

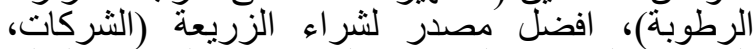

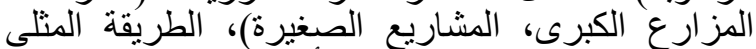

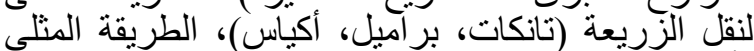
لأقلمة الزريعة (مر اعاة فروق حرارة، رطوبة).

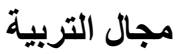

تم قياسه بمجموع خمسة بنود هيى: المساحة المثلى لئلى

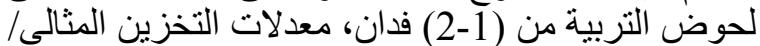

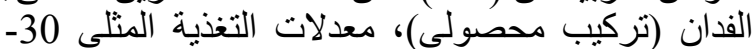

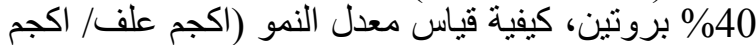

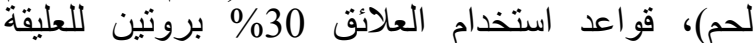

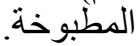

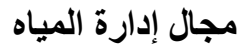

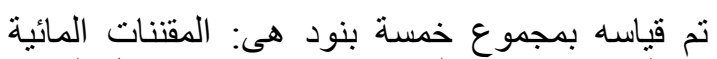

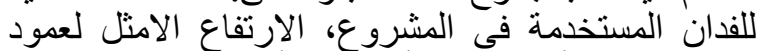

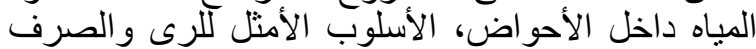
(صرف زراعى - آبار)، كيفية قياس خصوبة لآرى الإنياه

جدول 1. قيم معاملات الصدق والثبات للمقاييس الاتجاهية بالدراسة

\begin{tabular}{|c|c|c|c|c|c|}
\hline قيمة معامل & قيمة معامل الفا & الأنحراف & المتوسط & عدد & المقاييس \\
\hline 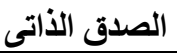 & كرونباخ & 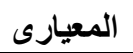 & 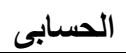 & 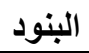 & اسم المتغير \\
\hline 0.914 & 0.836 & 7.961 & 39.437 & 16 & 1- السلوك الاستثمارى \\
\hline 0.782 & 0.612 & 2.831 & 30.425 & 12 & 2- درجة الأبتكارية \\
\hline 0.884 & 0.782 & 2.866 & 17.275 & 7 & 3- درجة القيادية \\
\hline 0.774 & 0.600 & 4.486 & 25.825 & 11 & 4- درجة الدافعية للإنجاز \\
\hline 0.779 & 0.608 & 3.236 & 20.650 & 9 & 5- المستوى الطموحى \\
\hline 0.819 & 0.671 & 4.304 & 19.450 & 9 & 6- القدرية و التواكلية \\
\hline 0.800 & 0.641 & 3.052 & 41.999 & 19 & 7- الاتجاه نحو التخطيط للمستقبل و العصرية \\
\hline
\end{tabular}


(40660-16000) جنيه، مصدر تمويلها كافي، تستخدم النظام غير المكتف في التربية، واكثريتها تقع ارباحها ما تانها

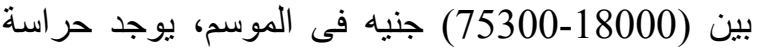

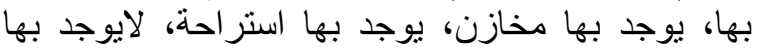
معمل تحليل، الدرجة الكلية للامكانيات البشرية والئلة المادية

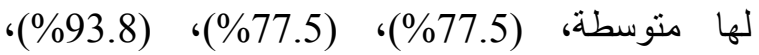
‘(\%66.3) ‘(\%66.3) ‘(\%55) ‘(\%61.3) (\%61.3) ، (\%51.3) ، (\%61.3) ، (\%50) ، (\%77.5) ،(\%91.3) ، (\%96.3) ‘(\%80) ‘(\%98.8) ،(\%75) . $(\% 56.3)$

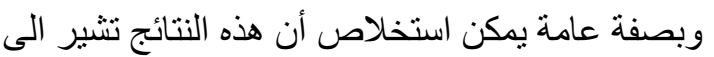

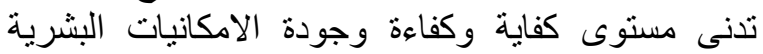

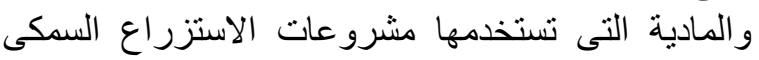

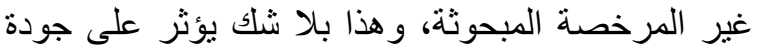
منتجات هذه المشرو عات من الأسمالك، و التأثثير سلبا على على

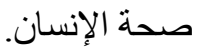

\section{درجة معرفة وتطبيق اصحاب مشروعات الاستزراع}

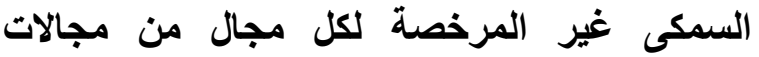

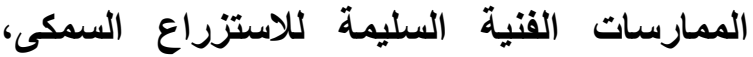

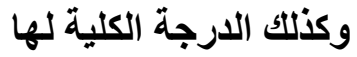

درجة المعرفة بكل مجال من مجالات الممارسات

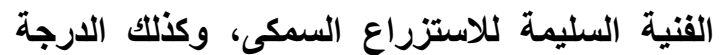
الكلية لها لـالئا

لتحقيق الهدف الثانى فى الجزئية المتعلقة بالتعرف

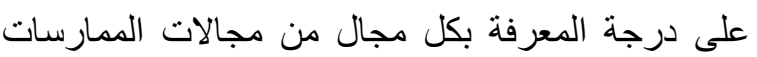

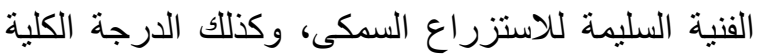
لها، تم حساب التكرارات والنسب المئوية ثم حساب النمات

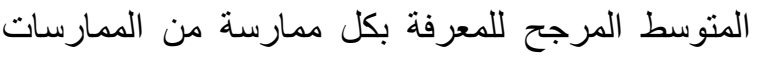

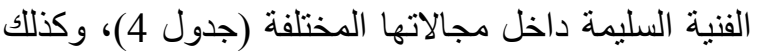
حساب التكر ارت و النسب المئوية للارجة الكلية لكل مجال

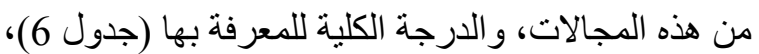
ومن النتائج الواردة بهذين الجدولين يتبين ما يلي:

\section{بالنسبة لمجال الممارسات الفنية المتعلقة بالإنثاءات}

وجد ان غالبية المبحوثين كانت الدرجة الكلية للمعرفة

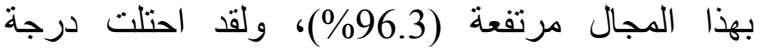
المعرفة بهذا المجال المرتبة الاولى من بين المجالات

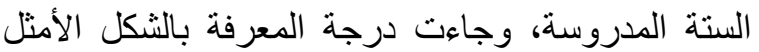

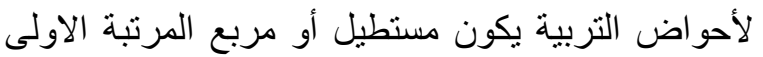

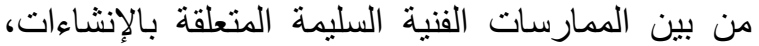

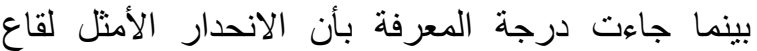
الحوض يكون بدرجة 120 درجة في المرنبة الأخيرة

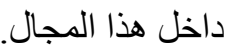

توصيف عينة الدراسة

يوضح جدول 2 بعض الخصائص الديموجرافية

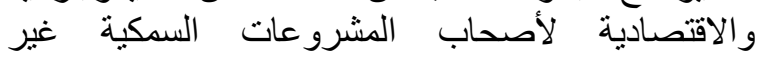
المرخصة حيث يتبين منه ان جميع الأنيع المبحوثين كانوا ذكور ا، و أكثريتهم (70\%) يقعون في الفئة العمرية (45 (45-

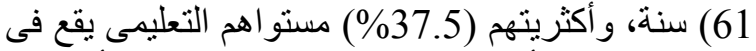
الفئة الجامعية، و أغلبيتهم متزوجون (51.5\%) (92.5\%)، و أغلبيتهم (81.3\%) تقع دخولهم الثهرية في الفئة (800 - 2480) جنيه، وأغلبيتهم (77.5\%) درجة كائة كفاية الدخل للمعيشة

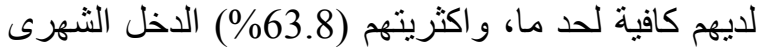
لأسرهم يقع فى الفئة (800 - 2480) جنيه، و واكثريتهم الائه

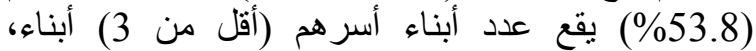

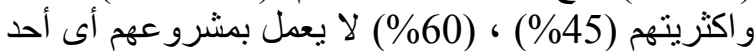

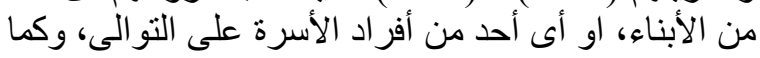

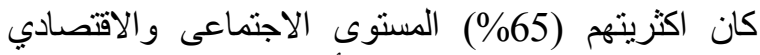

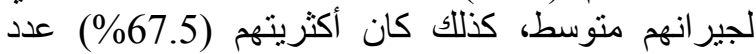

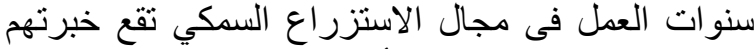

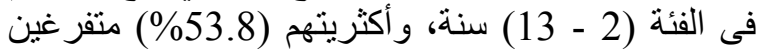

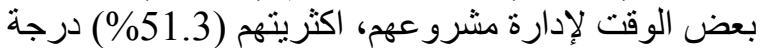

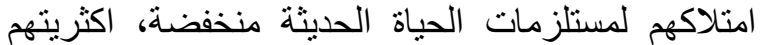

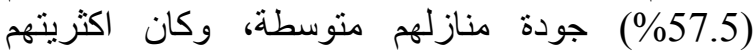

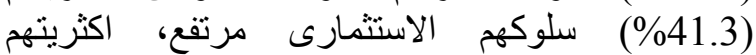

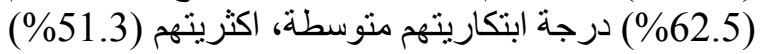

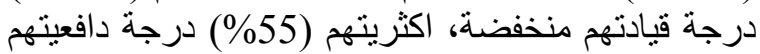

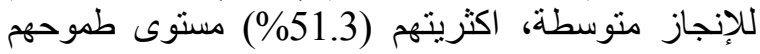
متوسط، اكثريتهم (58.8\%) درجة (57.5 القدرية و التوكلية لديهر منوسطة، اكثريتهم (67.5\%) اتجاههم نحو التخطيط للكستقبل و العصرية متوسط.

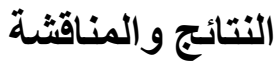

\section{مستوى الامكانيات البشرية والمادية لمشروعات

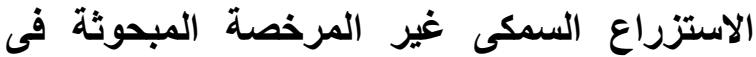 محافظة الشرقية}

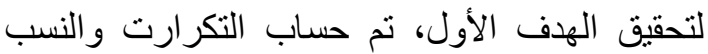

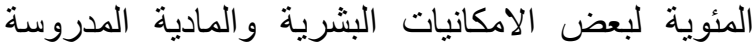

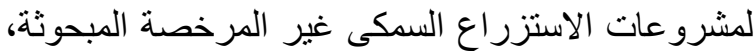

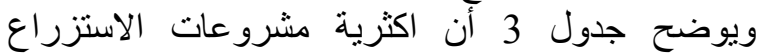

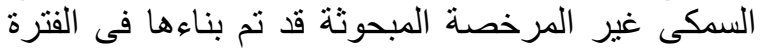

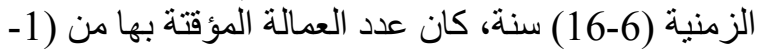

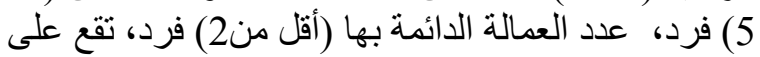

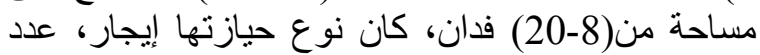

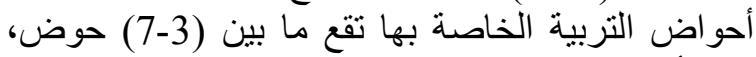

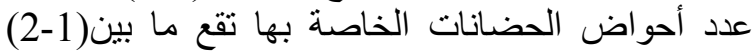
حوض، كان تمويلها ذاتى، تقدر تكاليفها الثابتة ما بين (12000 - 89600) جنيه، تقدر تكاليفها المتغيرة ما بين لتين 
جدول 2. التوزيع النسبي لبعض الخصائص الديموجرافية والاجتماعية والاقتصادية لأصحاب المشروعات السمكية غير

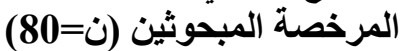

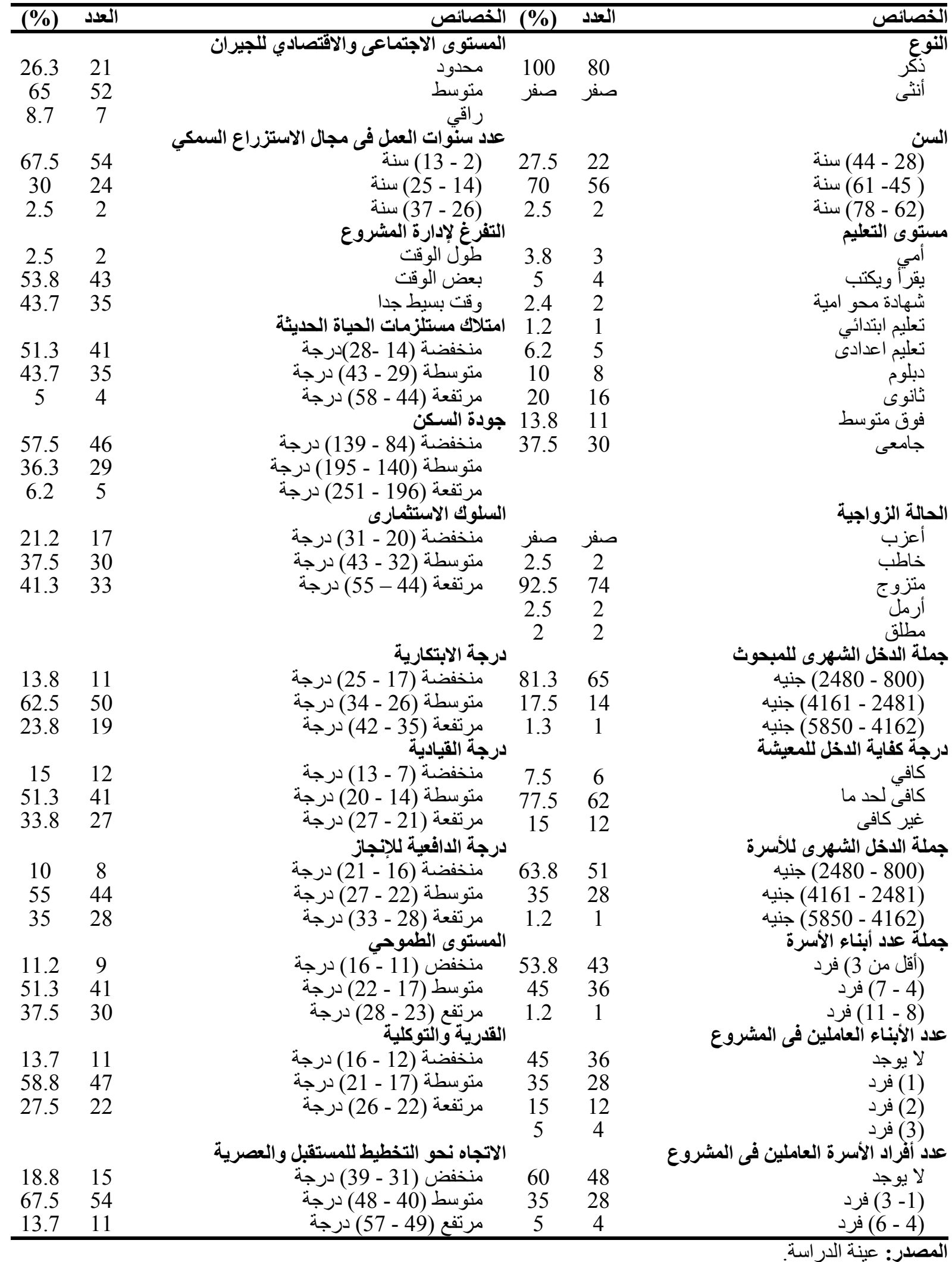


جدول 3. التوزيع النسبي لبعض الامكاتيات البشرية والمادية لمشروعات الاستزراع السمكى غير المرخصة المبحوثة

$(\mathbf{8 0}=\dot{0})$

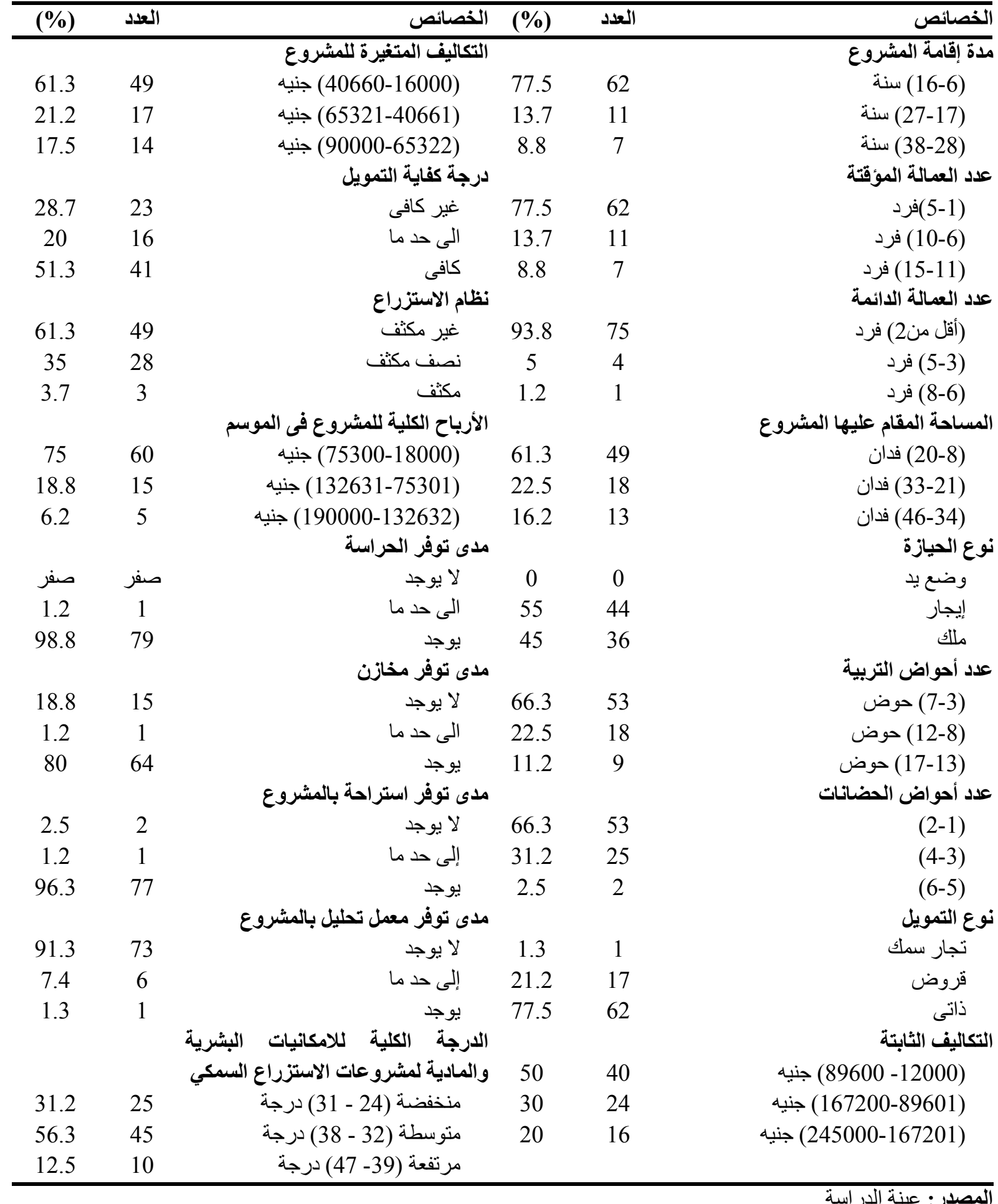


جذول 4. درجة معرفة أصحاب المشروعات السمكية غير المرخصة لكل مجال من مجالات الممارسات الفنية السليمة

\begin{tabular}{|c|c|c|c|c|c|c|c|c|c|c|}
\hline \multirow{5}{*}{ المجموعات } & \multirow{5}{*}{ للمجموعات المرجط } & \multirow{5}{*}{ الممارسيت } & \multirow{5}{*}{ 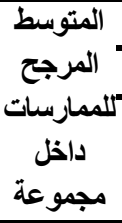 } & \multicolumn{6}{|c|}{ درجة المعرفة } & \multirow[t]{5}{*}{ الممارسات الفنية السليمة لمشروعات الاستزراع السمكى } \\
\hline & & & & \multicolumn{2}{|c|}{ ل الايعرف } & \multicolumn{2}{|c|}{ إلى حد ما } & \multicolumn{2}{|c|}{ ميعرف } & \\
\hline & & & & $(\%)$ & 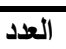 & $(\%)$ & 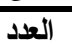 & $(\%)$ & 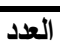 & \\
\hline & & & & & & & & & & \\
\hline & & & & & & & & & & \\
\hline \multirow[t]{6}{*}{1} & 39.67 & & & & & & & & & 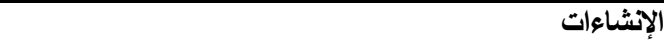 \\
\hline & & 3 & 39.6 & 1.3 & 1 & صفر & صفر & 98.8 & 79 & الاتجاه الأمنل لأحو اض المشروع من الثرق الى الغرب \\
\hline & & 3 & 39.6 & 1.3 & 1 & صفر & صفر & 98.8 & 79 & الارتفاع الأمثل لجسور المشروع لا يقل عن 2.1 متر \\
\hline & & 2 & 39.6 & 1.3 & 1 & صفر & صفر & 98.8 & 79 & عرض الجسور الرئيسية والفرعية لا يقل عن 3 مثر \\
\hline & & 1 & 40 & صفر & صفر & صفر & صفر & 100 & 80 & الثكل الأمنل لأحو اض التربية يكون مستطيل أو مربع \\
\hline & & 4 & 39.34 & 1.3 & 1 & 1.3 & 1 & 79.5 & 78 & الانحدار الأمثل لقاع الحوض يكون بدرجة 120 درجة \\
\hline \multirow[t]{7}{*}{3} & 33.6 & & & & & & & & & التحضين \\
\hline & & 3 & 34.67 & 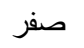 & صفر & 40 & 32 & 60 & 48 & المو اصفات المنلى للحضانة (نظيفة، خالية من الأتربة، مبطنة) \\
\hline & & 4 & 31.34 & 5 & 4 & 55 & 44 & 40 & 32 & كيفية تجهيز أحواض التحضين (التطهير، درجة الحرارة، \\
\hline & & & & & & & & & & 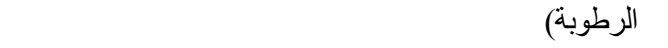 \\
\hline & & 1 & 37.67 & 2.5 & 2 & 12.5 & 10 & 85 & 68 & افضل مصدر لثر اء الزريعة (الثركات، الششروعات الكبرى) \\
\hline & & 2 & 37.34 & 2.5 & 2 & 15 & 12 & 82.5 & 66 & الطريقة المنلى لنقل الزريعة (تانكات، بر اميل، أكياس) \\
\hline & & 5 & 27 & 22.5 & 18 & 52.5 & 42 & 25 & 20 & الطريقة المثلى لأقلمة الزريعة (مر اعاة فروق حرارة، رطوبة) \\
\hline \multirow[t]{6}{*}{5} & 27.8 & & & & & & & & & التربية \\
\hline & & 1 & 35.67 & 7.5 & 6 & 17.5 & 14 & 75 & 60 & المساحة المثلى لحوض التربية من(1-2) فدان \\
\hline & & 2 & 28 & 20 & 16 & 50 & 40 & 30 & 24 & معدلات التخزين الدثالى/الفدان (تركيب محصولى) \\
\hline & & 3 & 25.67 & 35 & 28 & 37.5 & 30 & 27.5 & 22 & معدلات التغذية المثلى 30-40\% بروتين \\
\hline & & 3 & 25.67 & 40 & 32 & 27.5 & 22 & 32.5 & 26 & كيفية قياس معدل النمو (اكجم علف/ اكجم لحم) \\
\hline & & 4 & 24 & 47.5 & 38 & 25 & 20 & 27.5 & 22 & قو اعد استخدام العلائق 30\% بروتين للعليقة المطبوخة \\
\hline \multirow[t]{6}{*}{4} & 30 & & & & & & & & & إدارة المياه \\
\hline & & 3 & 29.34 & 32.5 & 26 & 15 & 12 & 52.6 & 42 & المقتنات المائية للفدان المستخدمة فى المشروع \\
\hline & & 1 & 36 & 5 & 4 & 20 & 16 & 75 & 60 & الارتفاع الامثل لعمود المياه داخل الأحو اض \\
\hline & & 1 & 36 & 10 & 8 & 10 & 8 & 80 & 64 & الأسلوب الأمثل للرى و الصرف (صرف زر اعى- آبار) \\
\hline & & 4 & 18.67 & 77.5 & 62 & 5 & 4 & 17.5 & 14 & 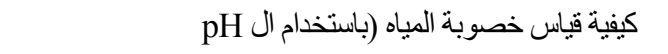 \\
\hline & & 2 & 30 & 25 & 20 & 25 & 20 & 50 & 40 & المعدل الأمتل لتغيير المياه يوميا من (6-9) ساعات \\
\hline \multirow[t]{6}{*}{6} & 25.2 & & & & & & & & & الامراض \\
\hline & & 1 & 30.34 & 27.5 & 22 & 17.5 & 14 & 55 & 44 & الامر اض الثائعة فى المشرو عات (الأيرومنانس، السبايروجليس) \\
\hline & & 2 & 28 & 20 & 16 & 50 & 40 & 30 & 24 & التشخيص المبكر للامر اض(الأعر اض الظاهرية) \\
\hline & & 5 & 22 & 55 & 44 & 25 & 20 & 20 & 16 & التأكد من الإصابة بالامر اض (بكثيريا- فطر-فيروس) \\
\hline & & 3 & 23.34 & 35 & 28 & 55 & 44 & 10 & 8 & كيفية الوقاية من الامر اض(ضبط الحر ارة- نسبة الأمونيا) \\
\hline & & 4 & 22.33 & 47.5 & 38 & 37.5 & 30 & 15 & 12 & كيفية علاج الامر اض(وصف الجرعات الدوائية المناسبة) \\
\hline \multirow[t]{6}{*}{2} & 33.72 & & & & & & & & & 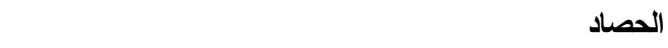 \\
\hline & & 1 & 38 & 2.5 & 2 & 10 & 8 & 87.5 & 70 & كيفية حساب الإنتاج المرتقب (حجم المبيعاتـ التكاليف) \\
\hline & & 3 & 34.3 & 7.5 & 6 & 27.5 & 22 & 65 & 52 & افضل ميعاد لتسويق الأسماك (الوزن المثالى_-موسمى) \\
\hline & & 2 & 37 & 5 & 4 & 12.5 & 10 & 82.5 & 66 & افضل توقيت لحصاد الأسماك (ليلا- الصباح الباكر) \\
\hline & & 4 & 31.67 & 5 & 4 & 52.5 & 42 & 42.5 & 34 & تهيئة وحصاد الأسماك (تجفيف الأحو اض- عن طريق الثباك) \\
\hline & & 5 & 27.67 & 20 & 16 & 52.5 & 42 & 27.5 & 22 & كيفية فرز وحفظ الأسماك (باستبعاد المريض ـالضعيف) \\
\hline
\end{tabular}


المجال فى المرتبة الثانية من بين المجالات الستة

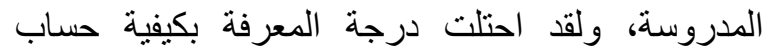

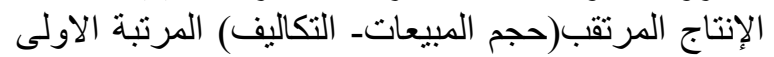

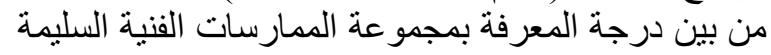

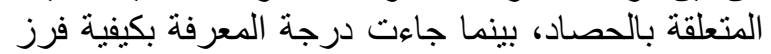

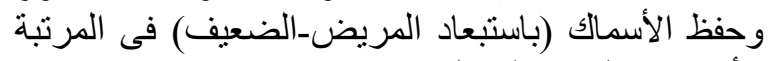

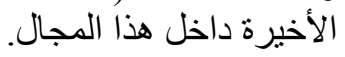

السليمبة للارجة الكلية للمعرفة بالممارسات الفنية

كان غالبية أصحاب مشروعات الاستزراع السمكى

(42.5\%) درجة معرفتهم بالممارسات الفنية السليمة السكية منوسطة.

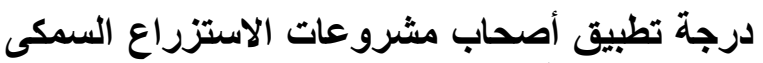

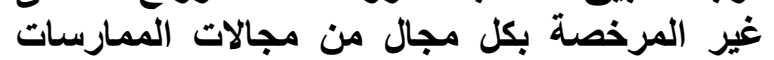

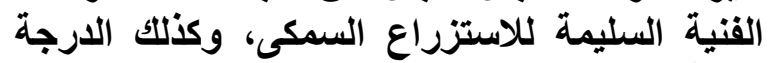

الكلية لها

لتحقيق الهدف الثانى فى الجزئية المتعلقة بالتعرف

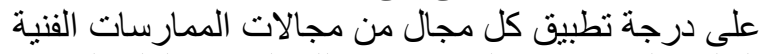

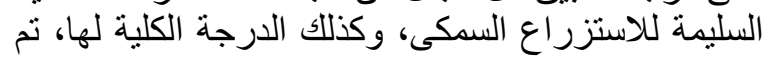
حساب التكرارات و النسب المئوية ثم حساب المنئ المتوسط المرجح لتطبيق كل ممارسة من الممارسات الفئة الفنية السليمة

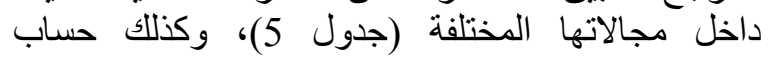

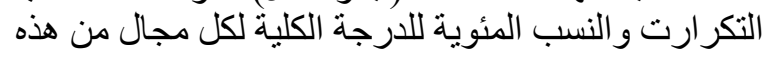

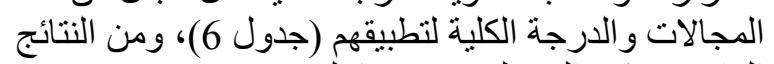
الو اردة بهذين الجدولين ينبين ما يلي:

\section{بالنسبة لمجال الممارسات الفنية المتعلقة بالإنشاءات التئين}

وجد ان غالبية المبحوثين كانت الدرجة الكلية للنطبيق

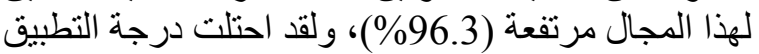

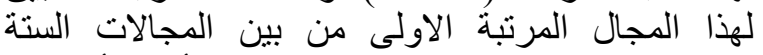

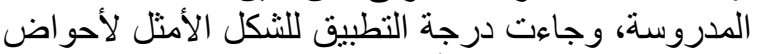

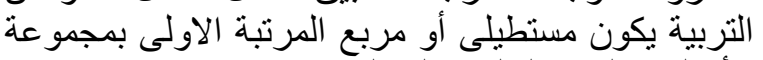

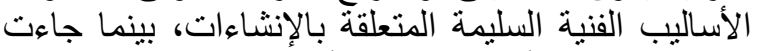

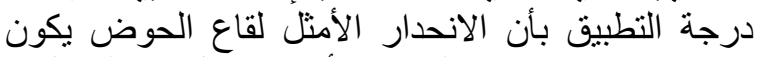
بدرجة 120 درجة في المرتبة الأخيرة داخل هذا المجال المال.

\section{بالنسبة لمجال الممارسات الفنية المتعلقة بالتحضين}

وجد ان غالبية المبحوثين كانت الدرجة الكلية للتطبيق

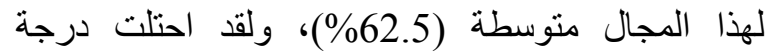
التطبيق لهذا المجال المرتبة الثالثة من بين المجالات التئة الستة

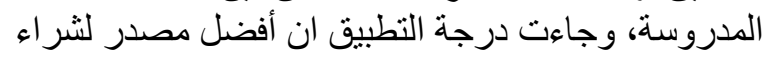

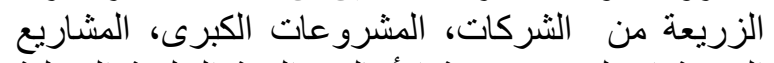

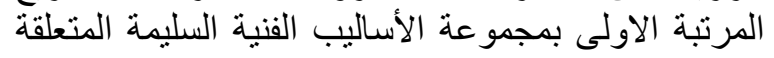

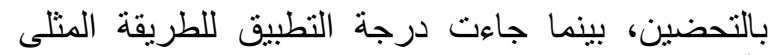

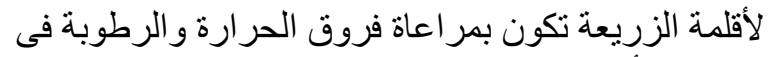
المرتبة الأخيرة داخل هذا المجال.
بالنسبة لمجال الممارسات القنية المتعلقة بالتحضين

وجد ان غالبية المبحوثين كانت الدرجة الكلية للمعرفة

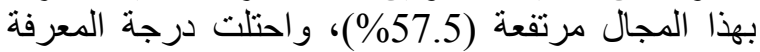
بهذا المجال المرنبة الثالثة من بين الثرالة المجالات الستة

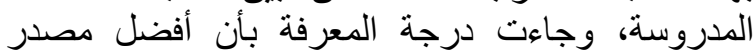

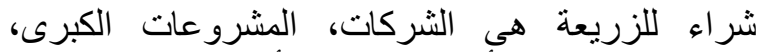

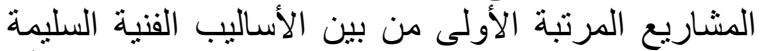

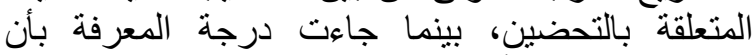

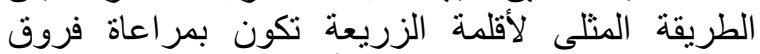
الحرارة و الرطوبة فى المرتبة الأخيرة داخل هذا المجال المجال.

\section{بالنسبة لمجال الممارسات الفنية المتعلقة بالتربية}

تبين ان غالبية المبحوثين كانت الدرجة الكلية للمعرفة

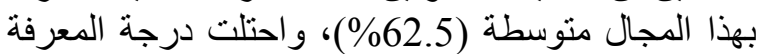
بهذا المجال المرتبة الخامسة من بينة المرالة المجالات الستة

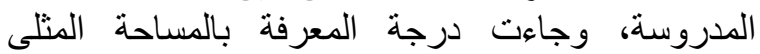
لحوض التربية من (1-2) فدان المرتبة الاولى درئه من بين

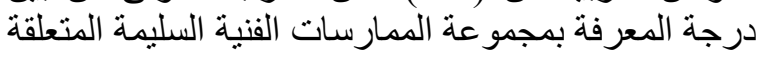

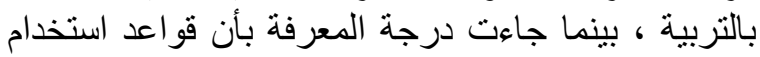

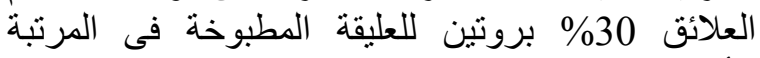

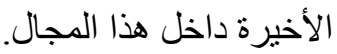

\section{بالنسبة لمجال الممارسات الفنية المتعلقة بإدارة المياه}

اتضح ان غالبية المبحوثين كانت الدرجة الكبلية

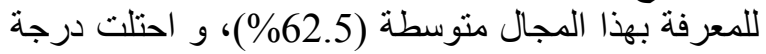

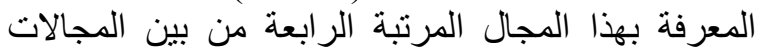

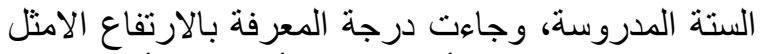

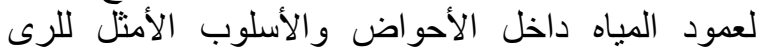

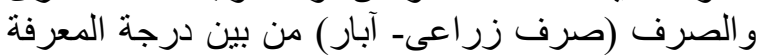

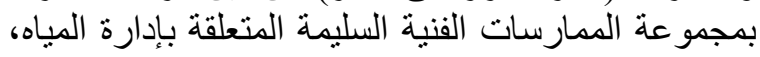

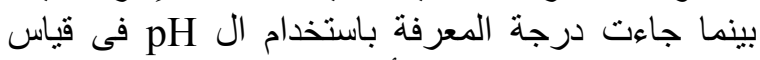

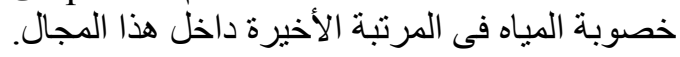

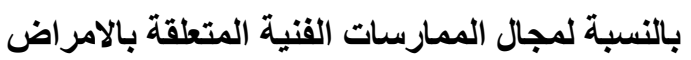

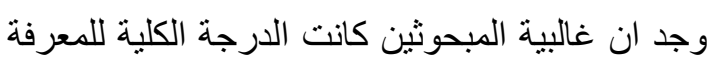

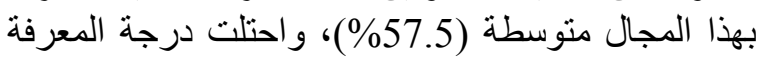

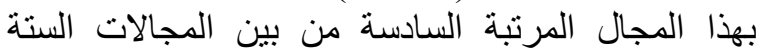

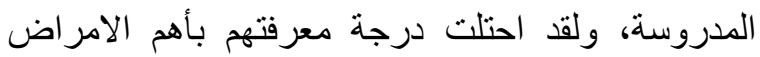

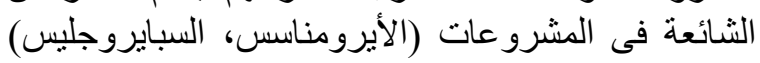

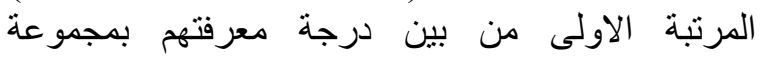

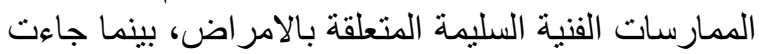

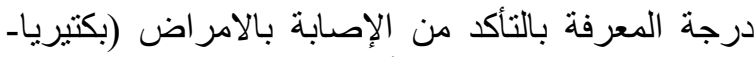

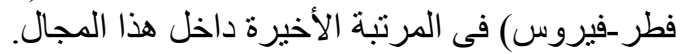

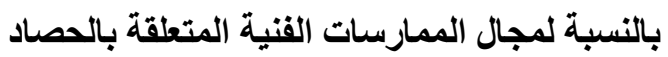

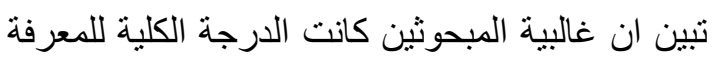

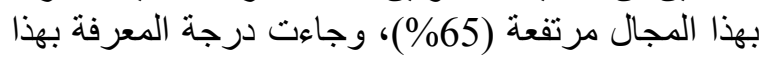


جذول 5. درجة تطبيق أصحاب المشروعات السمكية غير المرخصة لكل مجال من مجالات الممارسات الفنية السليمة

\begin{tabular}{|c|c|c|c|c|c|c|c|c|c|c|}
\hline \multirow{5}{*}{ المجموعات } & \multirow{5}{*}{ للمجموعات المرجح } & \multirow{5}{*}{ الممارسات } & \multirow{5}{*}{ 'للمارستات } & \multicolumn{6}{|c|}{ درجة التطبيق } & \multirow[t]{5}{*}{ الممارسات الفنية السليمة لمشروعات الاستزراع السمكى } \\
\hline & & & & \multicolumn{2}{|c|}{ ل ايعرف } & \multicolumn{2}{|c|}{ الى حد ما } & \multicolumn{2}{|c|}{ - يعرف } & \\
\hline & & & & $(\%)$ & العدد & $(\%)$ & العدد & $(\%)$ & العدد & \\
\hline & & & & & & & & & & \\
\hline & & & & & & & & & & \\
\hline \multirow[t]{6}{*}{1} & 39.66 & & & & & & & & & نشاءات \\
\hline & & 2 & 39.6 & 1.2 & 1 & صفر & صفر & 98.8 & 79 & الاتجاه الأمثل لأحو اض المشروع من الشرق الى الغرب \\
\hline & & 2 & 39.6 & 1.2 & 1 & صفر & صفر & 98.8 & 79 & الارتفاع الأمثل لجسور المشروعلايقل عن 2.1 مثر \\
\hline & & 2 & 39.6 & 1.2 & 1 & صفر & صفر & 98.8 & 79 & عرض الجسور الرئيسية و الفرعية لايقل عن 3 متر \\
\hline & & 1 & 40 & صفر & صفر & صفر & صفر & 100 & 80 & الثكل الأمتل لأحو اض التربية يكون مستطيل أو مربع \\
\hline & & 3 & 39.5 & 1.25 & 1 & 1.25 & 1 & 97.5 & 78 & الانحدار الأمثل لقاع الحوض يكون بدرجة 120 درجة \\
\hline \multirow[t]{7}{*}{3} & 27.9 & & & & & & & & & 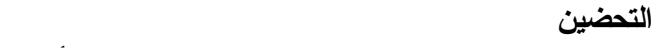 \\
\hline & & 3 & 34.6 & صفر & صفر & 40 & 32 & 60 & 48 & المواصفات المثلى للحضانة (نظيفة، خالية من الأتربة، \\
\hline & & 4 & 31 & 5 & 4 & 57.5 & 46 & 37.5 & 30 & 2.كيفية تجهيز أحواض التحضين(التطهير،درجة الحرارة، \\
\hline & & & & & & & & & & 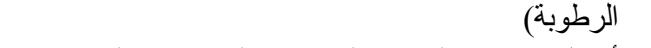 \\
\hline & & 1 & 38 & 2.5 & 2 & 10 & 8 & 87.5 & 70 & أفضل مصدر لشراء الزريعة (الثركات، المشروعات \\
\hline & & 2 & 37.3 & 2.5 & 2 & 15 & 12 & 82.5 & 66 & الطريقة المثلى لنقل الزريعة (تانكات، بر اميل، أكياس) \\
\hline & & 5 & 26.6 & 25 & 20 & 50 & 40 & 25 & 20 & الطريقة المتلى لأقلمة الزريعة (مراعاة فروق حرارة، \\
\hline \multirow{7}{*}{4} & & & & & & & & & & 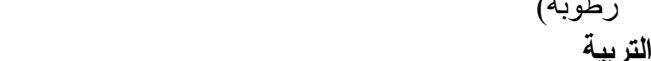 \\
\hline & 20.1 & & & & & 375 & & 525 & 42 & المساحة المثلى لحوض التربية من(1-2) فدان \\
\hline & & 1 & 32.3 & 10 & 8 & 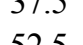 & 30 & 32.3 & 42 & 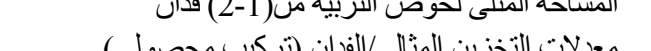 \\
\hline & & 2 & 27.6 & 20 & 16 & 52.5 & 42 & 27.5 & 22 & معدلات التخزين المثالى/الفدان (تركيب محصولى) \\
\hline & & 5 & 22.3 & 47.5 & 38 & 37.5 & 30 & 15 & 12 & معدلات التغذية المثلى 30-40\% بروتين \\
\hline & & 3 & 25 & 42.5 & 34 & 27.5 & 22 & 30 & 24 & كيفية قياس معدل النمو (اكجم علف/ اكجم لحم) \\
\hline & & 4 & 23.3 & 50 & 40 & 25 & 20 & 25 & 20 & قو اعد استخدام العلائق 30\% بروتين للعليقة المطبوخة \\
\hline \multirow[t]{6}{*}{5} & 23.5 & & & & & & & & & 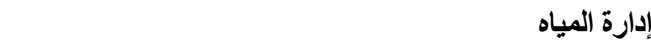 \\
\hline & & 3 & 28.3 & 35 & 28 & 17.5 & 14 & 47.5 & 38 & المقنتات المائية للفدان المستخدمة فى المشروع \\
\hline & & 1 & 35.6 & 5 & 4 & 22.5 & 18 & 72.5 & 58 & الارتفاع الامتل لعمود المياه داخل الأحو اض \\
\hline & & 2 & 34 & 12.5 & 10 & 20 & 16 & 67.5 & 54 & الأسلوب الأمثل للرى و الصرف (صرف زر اعى- آبار) \\
\hline & & 5 & 18.6 & 77.5 & 62 & 5 & 4 & 17.5 & 14 & كيفية قياس خصوبة المياه (باستخدام ال pH \\
\hline & & 4 & 24.6 & 45 & 36 & 25 & 20 & 30 & 24 & المعدل الأمثل لتغيير المياه يو يبا من (6-9) ساعات \\
\hline \multirow[t]{6}{*}{6} & 20.5 & & & & & & & & & 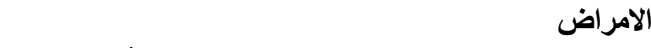 \\
\hline & & 1 & 29 & 32.5 & 26 & 17.5 & 14 & 50 & 40 & الامراض الثائعة فى المشروعات (الأيرومناسس، \\
\hline & & 2 & 27 & 22.5 & 18 & 52.5 & 42 & 25 & 20 & التشخيص المبكر للادر اض(الأعر اض الظاهرية) \\
\hline & & 5 & 21.6 & 55 & 44 & 27.5 & 22 & 17.5 & 14 & التأكد من الإصابة بالامر اض (بكتيريا- فطر-فيروس) \\
\hline & & 3 & 23.3 & 35 & 28 & 55 & 44 & 10 & 8 & كيفية الوقاية من الامر اض(ضبط الحر ارة- نسبة الأمونيا) \\
\hline & & 4 & 22.3 & 45 & 36 & 42.5 & 34 & 12.5 & 10 & كيفية علاج الامر اض(وصف الجرعات الدوائية المناسبة) \\
\hline \multirow[t]{6}{*}{2} & 28.25 & & & & & & & & & حصاد \\
\hline & & 1 & 38.3 & 2.5 & 2 & 7.5 & 6 & 90 & 72 & كيفية حساب الإتتاج المرتقب (حجم المبيعاتـ التكاليف) \\
\hline & & 3 & 34.6 & 7.5 & 6 & 25 & 20 & 67.5 & 54 & أفضل ميعاد لتسويق الأسماك (الوزن المثالى_-موسمى) \\
\hline & & 2 & 37.3 & 5 & 4 & 10 & 8 & 85 & 68 & أفضل توقيت لحصاد الأسماك (ليلاـ الصباح الباكر) \\
\hline & & 4 & 32 & 5 & 4 & 50 & 40 & 45 & 36 & تهيئة وحصاد الأسماك (تجفيف الأحواض - عن طريق \\
\hline & & 5 & 27.3 & 22.5 & 18 & 50 & 40 & 27.5 & 22 & كيفية فرز وحفظ الأسماك (باستبعاد المريض ـالضعيف) \\
\hline
\end{tabular}


Zagazig J. Agric. Res., Vol. 44 No. (2) 2017

جدول 6. التوزيع النسبي للارجة الكلية لمعرفة وتطبيق أصحاب مشروعات الاستزراع السمكى غير المرخصة لمجالات

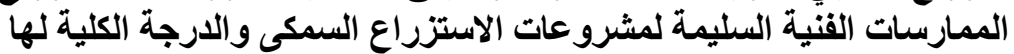

\begin{tabular}{|c|c|c|c|c|c|}
\hline \multirow[t]{2}{*}{$(\%)$} & عدد & \multicolumn{2}{|c|}{ (\%) درجة التطبيق } & \multicolumn{2}{|r|}{ درجة المعرفة $\quad$ علد } \\
\hline & \multicolumn{3}{|c|}{ اللممارسكى الفنية السليمة لمشروعات الاستزراع } & \multicolumn{2}{|r|}{ السمكمى المسات القنية السليمة لمشروعات الاستزراع } \\
\hline \multicolumn{5}{|c|}{ الارجة الكلية للتطبيق فى مجال الإنشاءات } & الارجةٌ الكلية للمعرفة بمجال الإنشاءات \\
\hline 1.2 & 1 & منخفضة (3-6) درجة & 1.2 & 1 & منخفضة (11-12) درجة \\
\hline 2.5 & 2 & منوسطة (7-10) درجة & 2.5 & 2 & متوسطة (13-14) درجة \\
\hline 96.3 & 77 & مرتفعة(11-14) درجة & 96.3 & 77 & مرتفعة (15-16) درجة \\
\hline \multicolumn{5}{|c|}{ الدرجة الكلية للتطبيق فى مجال التحضين } & الدرجة الكلية للمعرفة بمجال التحضين \\
\hline 17.5 & 14 & منخفضة (2-5) درجة & 15 & 12 & منخفضة (10-11) درجة \\
\hline 62.5 & 50 & متوسطة (6-9) درجة & 27.5 & 22 & متوسطة (12-13) درجة \\
\hline 20 & 16 & مرتفعة (10-13) درجة & 57.5 & 46 & مرتفعة(14-15) درجة \\
\hline \multicolumn{5}{|c|}{ الدرجة الكلية للتطبيق فى مجال التربية } & الارجة الكلية للمعرفة بمجال التربية \\
\hline 17.5 & 14 & منخفضة (7-9) درجة & 10 & 8 & منخفضة (6-8) درجة \\
\hline 65 & 52 & متوسطة (10-12) درجة & 62.5 & 50 & متو سطة (9-11) درجة \\
\hline 17.5 & 14 & مرتفعة(13-15) درجة & 27.5 & 22 & مرتفعة (12-14) درجة \\
\hline \multicolumn{5}{|c|}{ الدرجة الكلية للتطبيق فى مجال إدارة المياه } & الدرجة الكلية للمعرفة بمجال إدارة المياه \\
\hline 15 & 12 & منخفضة (7-9) درجة & 10 & 8 & منخفضة (8-9) درجة \\
\hline 35 & 28 & منوسطة (10-12) درجة & 62.5 & 5 & منوسطة (10-11) درجة \\
\hline 50 & 40 & مرتفعة(13-15) درجة & 27.5 & 22 & مرتفعة (12-12) درجة \\
\hline \multicolumn{5}{|c|}{ الارجة الكلية للتطبيق فى مجال الامر اض } & الدرجة الكلية للمعرفة بمجال الامراض \\
\hline 30 & 24 & منخفضة (5-8) درجة & 32.5 & 26 & منخفضة (5-8) درجة \\
\hline 57.5 & 46 & منوسطة (9-12) درجة & 57.5 & 46 & منوسطة (9-12) درجة \\
\hline 12.5 & 10 & مرتفعة(13-16) درجة & 10 & 8 & مرتفعة (13-16) درجة \\
\hline \multicolumn{5}{|c|}{ الارجة الكلية للتطبيق فى مجال الحصاد } & الدرجة الكلية للمعرفة بمجال الحصاد \\
\hline 10 & 8 & منخفضة (9-10) درجة & 7.5 & 6 & منخفضة (9-10) درجة \\
\hline 27.5 & 22 & متوسطة (11-12) درجة & 27.5 & 22 & متوسطة (11-12) درجة \\
\hline 62.5 & 50 & مرتفعة(13-15) درجة & 65 & 52 & مرتفعة (13-15) درجة \\
\hline \multicolumn{5}{|c|}{ 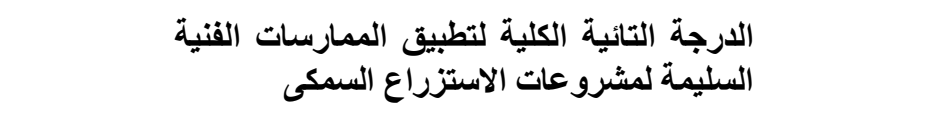 } & \multirow[t]{4}{*}{ 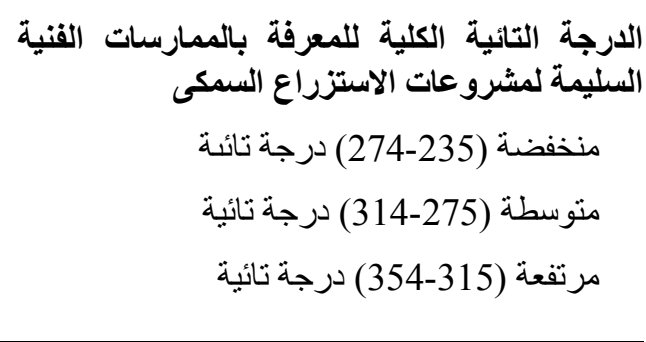 } \\
\hline 16.2 & 13 & منخفضة (220-264) درجة تائية & 21.2 & 17 & \\
\hline 45 & 36 & متوسطة (265-310) درجة تائية & 42.5 & 34 & \\
\hline 38.8 & 31 & مرتفعة(311-355) درجة تائية & 36.3 & 29 & \\
\hline
\end{tabular}


العلاقـات الارتباطيـه بين بعض المتغيرات المستيتقة

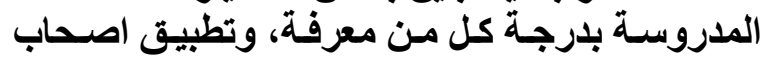

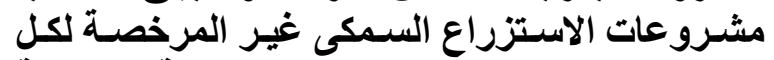

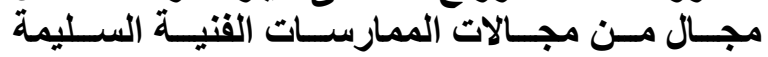

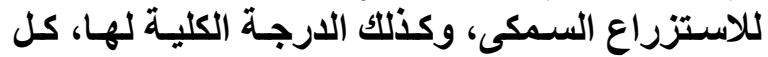
على حدى لإستر

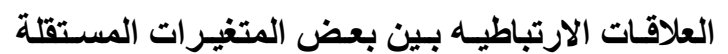

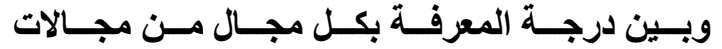

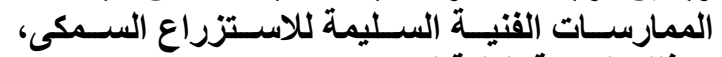
وكذلك الارجة الكلية لها

لتحقيق الهدف الثالث فى الجزئية المتعلقة بالتعرف

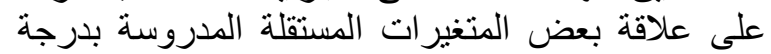

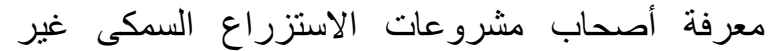
المرخصة لكل مجال من مجالات المات الممارسات المات الفنية

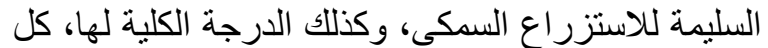

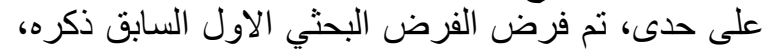

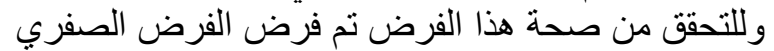

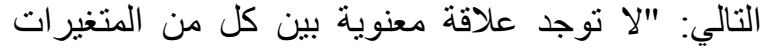

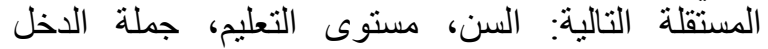

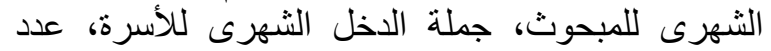

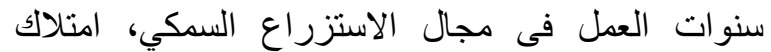

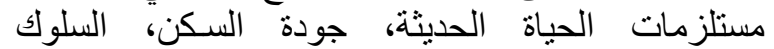

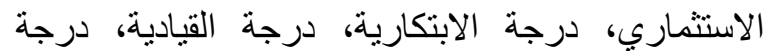

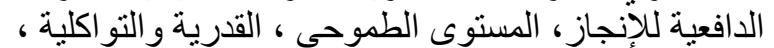

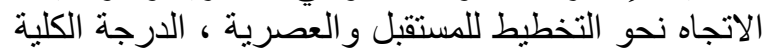

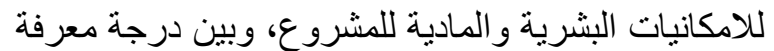

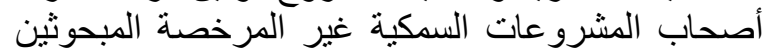

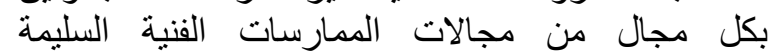

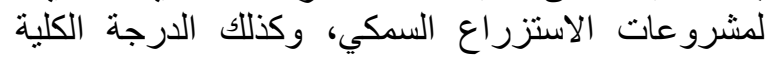

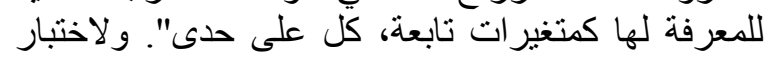

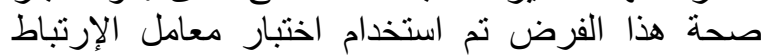

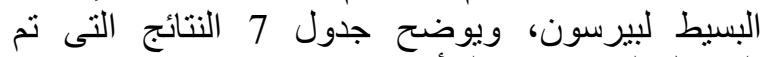
التوصل اليها في هذا الثنأن:

بالنسبة لارجة المعرفة بالممارسات الفنية الخاصة بالإنشاءات لات

يتضح وجود علاقة ارتباطبه معنوية موجبة عند الإبناءية

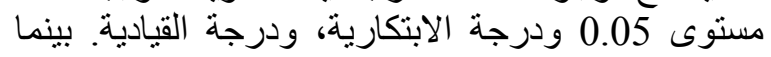
وجد هنالك وجود علاقة ارتباطيه معنوية سالبة عندية عندانية

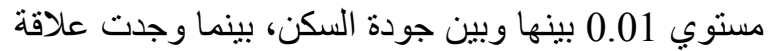

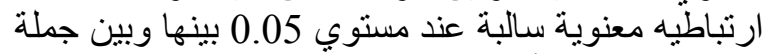
الدخل الثهرى للأسرة، الدافعية للإنجاز.

بالنسبة لارجة المعرفة بالممارسات الفنية الخاصة بالتحضين لم يتبين وجود اى علاقة معنوية بينها وبين كل من النين المتغير ات المستقلة المدروسة، كل على حلى حدى.
بالنسبة لمجال الممارسات القنية المتعلقة بالتربية تبين ان غالبية المبحوثين كانت الدرجة الكلية للتطبيق

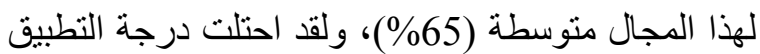

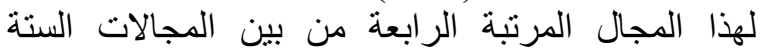

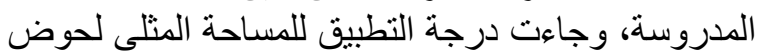

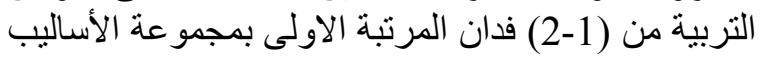

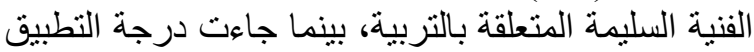

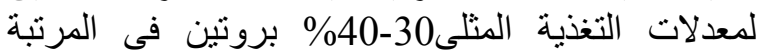

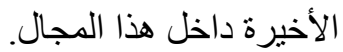

\section{بالنسبة لمجال الممارسات الفتية المتعقة بإدارة المياه}

اتضح ان غالبية المبحوثين كانت الدرجة الكلية

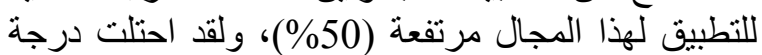

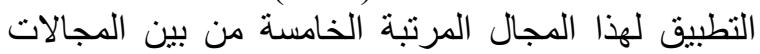

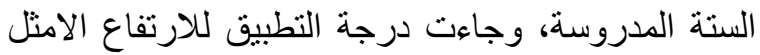

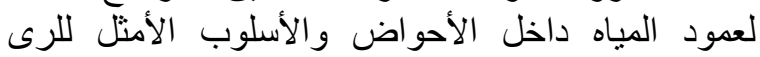

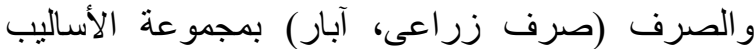

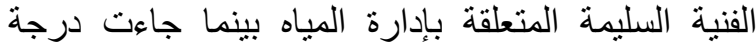
التطبيق باستخدام ال pH في قياس خصوة النياه المرتبة الأخيرة داخل هذا المجال.

\section{بالنسبة لمجال الممارسات الفنية المتعلقة بالامراض}

وجد ان غالبية المبحوثين كانت الدرجة الكلية للتطبيق

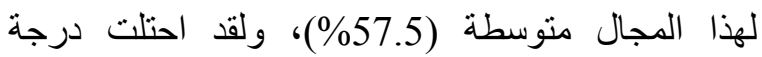
التطبيق لهذا المجال المرتبة السادسة من بين المجالاتلات

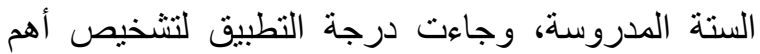

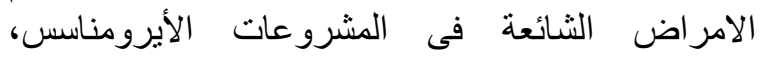
السبايروجليس المرتبة الاولى بمجموعة الأساليب الفنية

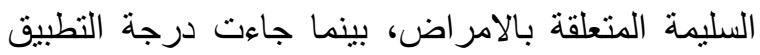

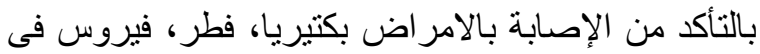
المرتبة الأخيرة داخل هذا المجال.

\section{بالنسبة لمجال الممارسات الفنية المتعلقة بالحصاد}

وجد ان غالبية المبحوثين كانت الدرجة الكلية للتطبيق

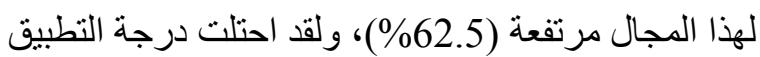

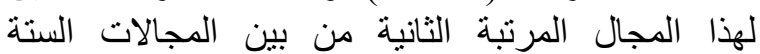
المدروسة، وجاءت درجة التطبيق بكيفية حساب الإنتانة الإنتاج

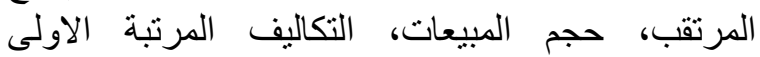

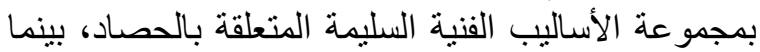

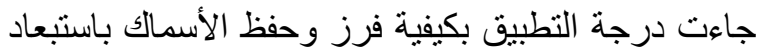

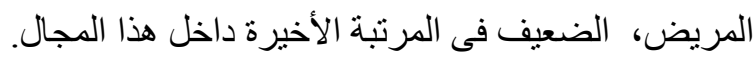

بالنسبة للارجة الكلية للتطبيق للممارسات الفنية السليمة كان اكثرية اصحاب مشروعات الاستزراع السمكى (45\%) درجة تطبيقهم للممارسات الفنية السليمة منوسطة. 
جدول 7. معاملات الارتباط البسيط لبيرسون (r) بين المتغيرات المستقلة وبين درجة المعرفة بكل مجال من مجالات

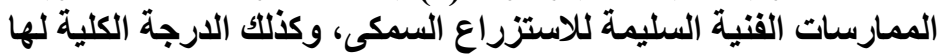

\begin{tabular}{|c|c|c|c|c|c|c|c|}
\hline & \multicolumn{5}{|c|}{ درجة المعرفة بالممارسات الفنية السليمة } & \multicolumn{2}{|r|}{ قيمة معاملات الارتباط بيرسون (Y) } \\
\hline اللارجة الكلية & الحصاد & الامراض & 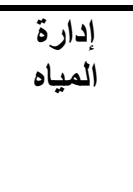 & التربية & التحضين & الإنشاء|ت & ذات الطبقة الفترية المستقلة المدروسة \\
\hline 0.065 & $0.057-$ & 0.053 & $0.048-$ & $0.058-$ & $0.045-$ & $0.073-$ & 1- 1 - 1السن \\
\hline 0.122 & $0.065-$ & $0.064-$ & 0.072 & 0.158 & 0.039 & 0.109 & 2- عدد سنوات التعليم الرسمي \\
\hline 0.139 & 0.121 & 0.129 & 0.09 & 0.120 & 0.113 & $0.234-*$ & 3- جملة الدخل الثهرى للمبحوث \\
\hline $0.16-$ & 0.107 & 0.005 & $0.145-$ & 0.114 & 0.022 & $0.130-$ & 4- جملة الاخل الشهرى للأسرة \\
\hline 0.035 & $0.019 *$ & 0.180 & 0.059 & 0.085 & $0.017-$ & $0.217-$ & 5- عدد سنوات العمل فى مجال الاستزراع السمكي \\
\hline $0.247 * *_{-}$ & $0.048-$ & 0.215 & 0.135 & $0.269 * *$ & 0.022 & $0.013-$ & 6- امتلاك مستلزمات الحياة الحديثة \\
\hline $0.224 * *$ & 0.147 & 0.01 & 0.096 & 0.138 & 0.027 & $0.331-* *$ & 7- جودة السكن \\
\hline 0.186 & 0.09 & 0.106 & 0.02 & $0.24 * *$ & 0.150 & $0.04-$ & 8- السلوك الاستثماري \\
\hline 0.035 & 0.068 & $0.227-*$ & $0.154-$ & 0.058 & 0.077 & $0.0242 *$ & 9- درجة الابتكارية \\
\hline 0.188 & $0.089-$ & $0.052-$ & 0.072 & 0.156 & 0.118 & $0.0234^{*}$ & 10- درجة القيادية \\
\hline $0.237^{*}$ & 0.096 & 0.058 & 0.087 & 0.045 & 0.117 & $0.237-*$ & 11- درجة الدافعية للإنجاز \\
\hline .037 & 0.051 & $0.043-$ & 0.141 & $0.028-$ & 0.092 & $0.008-$ & 12- المستوى الطموحي \\
\hline $0.087-$ & $0.069-$ & 0.181 & $0.009-$ & 0.184 & 0.06 & $0.159-$ & 13- القدرية و التوكلية \\
\hline 0.18 & $0.027-$ & 0.034 & 0.01 & 0.146 & 0.124 & $0.017-$ & 14- التخطيط للمستقبل والعصرية \\
\hline $0.226^{*}$ & $0.007-$ & 0.111 & $0.012-$ & $0.248^{*}$ & $0.095-$ & 0.019 & 15- اللارجة الكلية للامكانيات البشرية والمادية \\
\hline
\end{tabular}

0.01 معنوي عند مستوى 0.05 **منوي عند مستوى

بالنسبة لدرجة المعرفة بالممارسات الفنية الخاصة بالحصاد

يتضح وجود علاقة ارتباطيه معنوية موجبة عند المبند

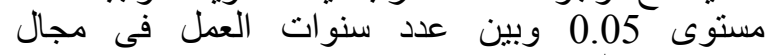
الاستزراع السمكي.

بالنسبة للارجة الكلية للمعرفة بالممارسات الفنية

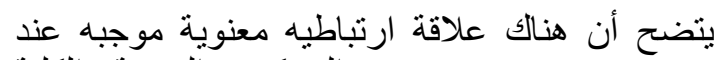

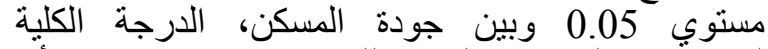

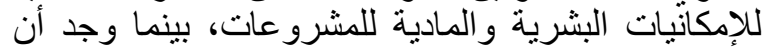
هنالك علاقة ارتباطية معنوية موجبة لإنة عند مستوى 0.05

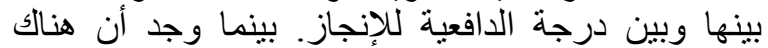

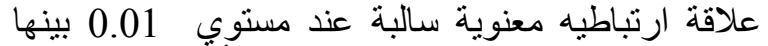

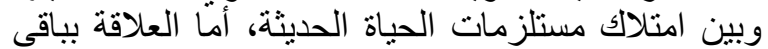
الكتغير ات فكانت غير معنوية. يمكن قبول الفرض الصفري السابق بالنسبة للمتغيرات
بالنسبة لارجة المعرفة بالممارسات القنية الخاصة بالتربية

يتضح ان هناك علاقة ارتباطيه معنوية موجبه عند مستوي 0.01 وبين امتلاك مستلزمات الحئه الحياة الحديثة، مبنة السلوك الاستثماري.

بالنسبة لارجة المعرفة بالممارسات الفنية الخاصة

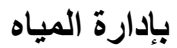

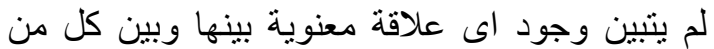

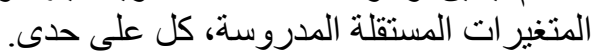

بالنسبة لارجة المعرفة بالممارسات الفنية الخاصة بالامر اض لاض يتضح وجود علاقة ارتباطيه معنوية سالبة عند مستوي 0.01 وبين درجة الأبتكارية. 
بالنسبة لدرجـة التطبيق للممارسـات الفنيـة الخاصـة

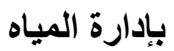

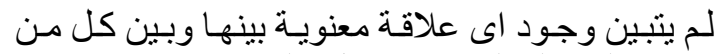
المتغير ات المستقلة المدروسة، كل على حدة.

بالنسبة لارجـة التطبيق للممارسـات الفنيـة الخاصـة بالامراض لباض لاض

يتضح وجود علاقة ارتباطيه معنوية سالبة عند مستوي 0.05 بينها وبين درجة الأبنكارية.

بالنسبة لارجـة التطبيق للممارسـات القتيـة الخاصـة بالحصاد بالن باد

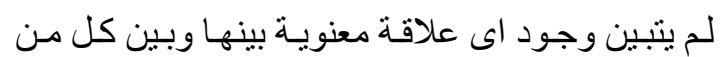

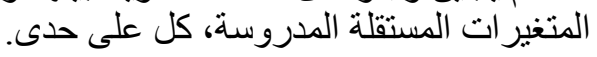

بالنسبة للارجة الكلية للتطبيق للممارسات الفنية

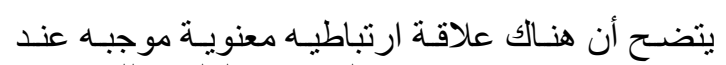

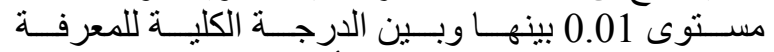
بالممارسات الفنية، بينما يتضـح أن هنالك علاقة ارتباطيه

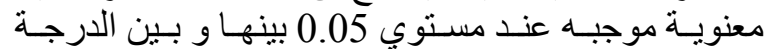

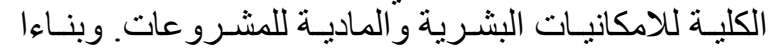

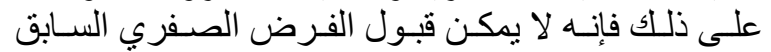

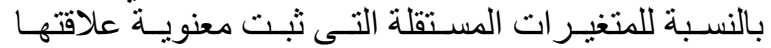

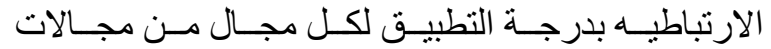

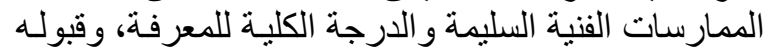
بالنسب للمتغير ات التى لم تتبت معنوية علاقتها.

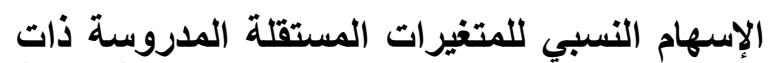

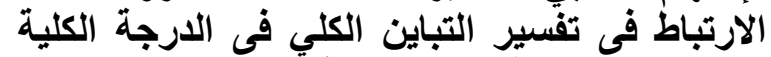

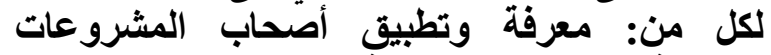

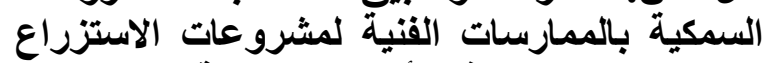
السمكى، وترتيبها وفقا لأهميتها النسبية لمبية

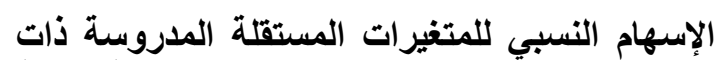

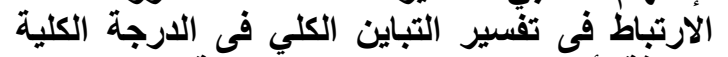

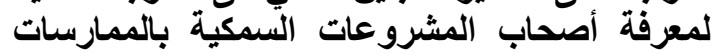
الفنية لمشروعات الاستزراع السمكى، وترتيبها وفقات المئرات لأهميتها النسبية

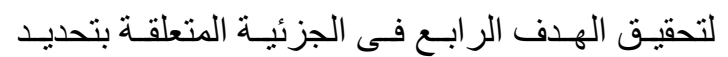

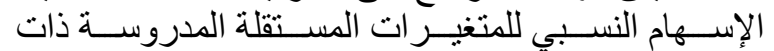

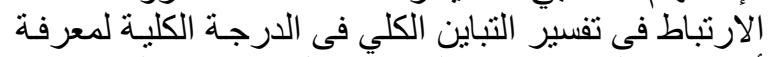

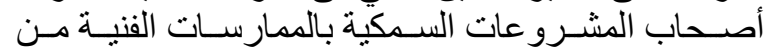

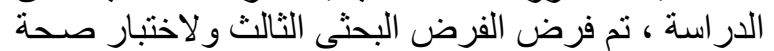

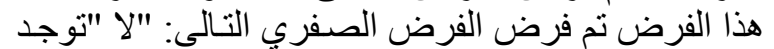

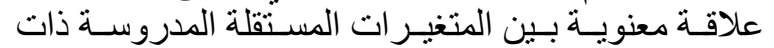

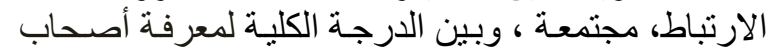

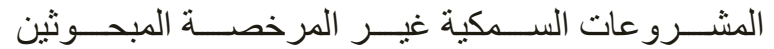

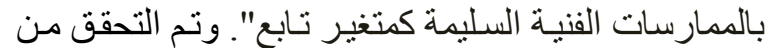

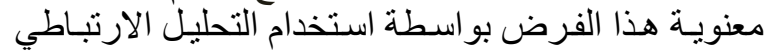

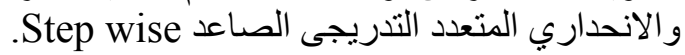

المستقلة التى ثبت معنوية علاقتها الارتباطيه بدرجة

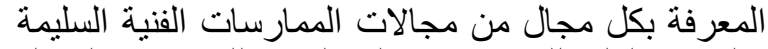

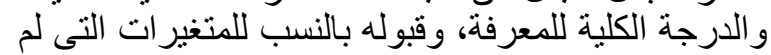
تثبت معنوية علاقتها.

العلاقات الارتباطيه بين بعض من المتفيرات المستقلة

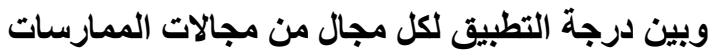

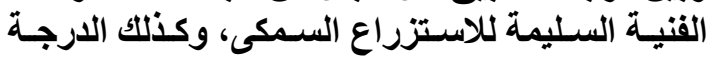
الكلية لها

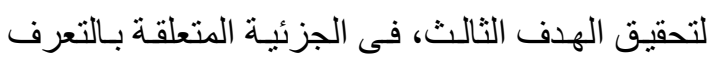

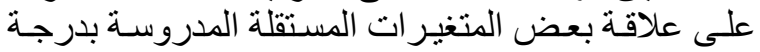

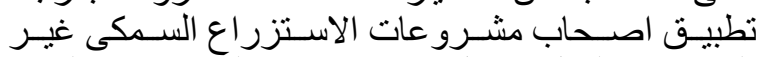

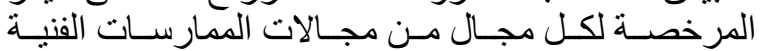

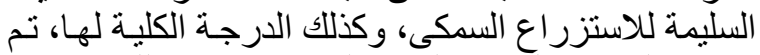

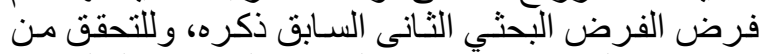

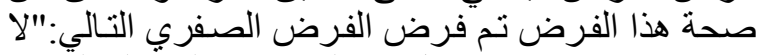

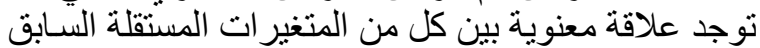

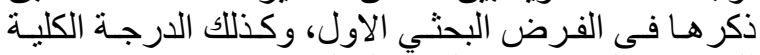

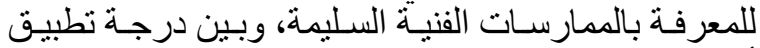

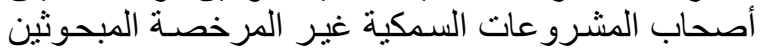

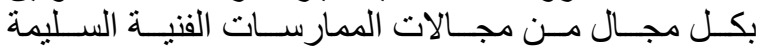

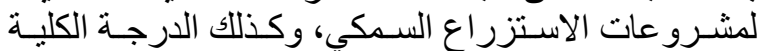

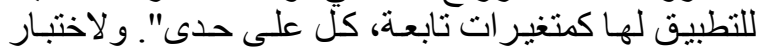

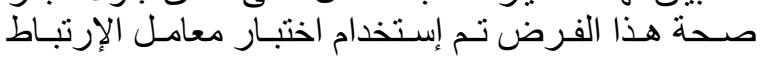

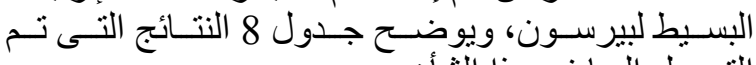
التوصل البيها في هذا الثنأن:

بالنسبة لإرجـة التطبيق للممارسـات الفنيـة الخاصـة بالإنشاءات لات

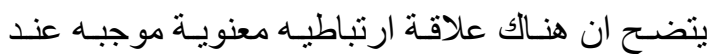

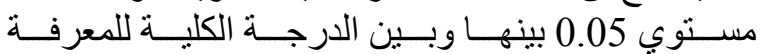
بالممارسات الفنية.

بالنسـبة لدرجـة التطبيق للممارســات الفنيـة الخاصـة بالتحضين

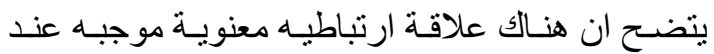

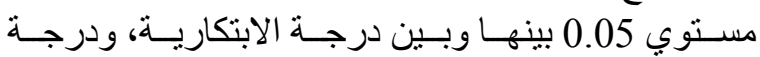

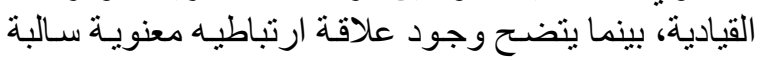

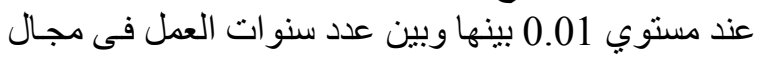

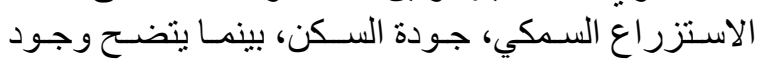

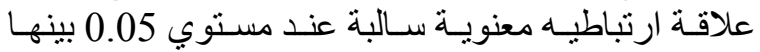
وبين درجة الدافعية للإنجاز .

بالنسبة لارجـة التطبيتق للممارسـات الفنيـة الخاصـة بالتربية

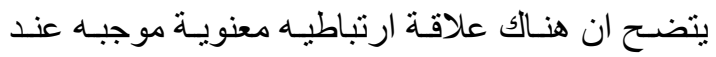

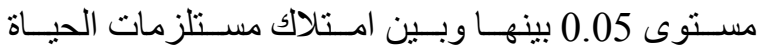

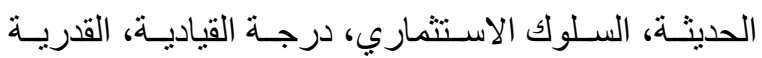
و التوكلية. 
جدول 8. معاملات الارتباط البسيط لبيرسون (r) بين المتغيرات المستقلة وبين درجة التطبيق لكل مجال من مجالات

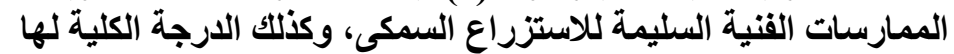

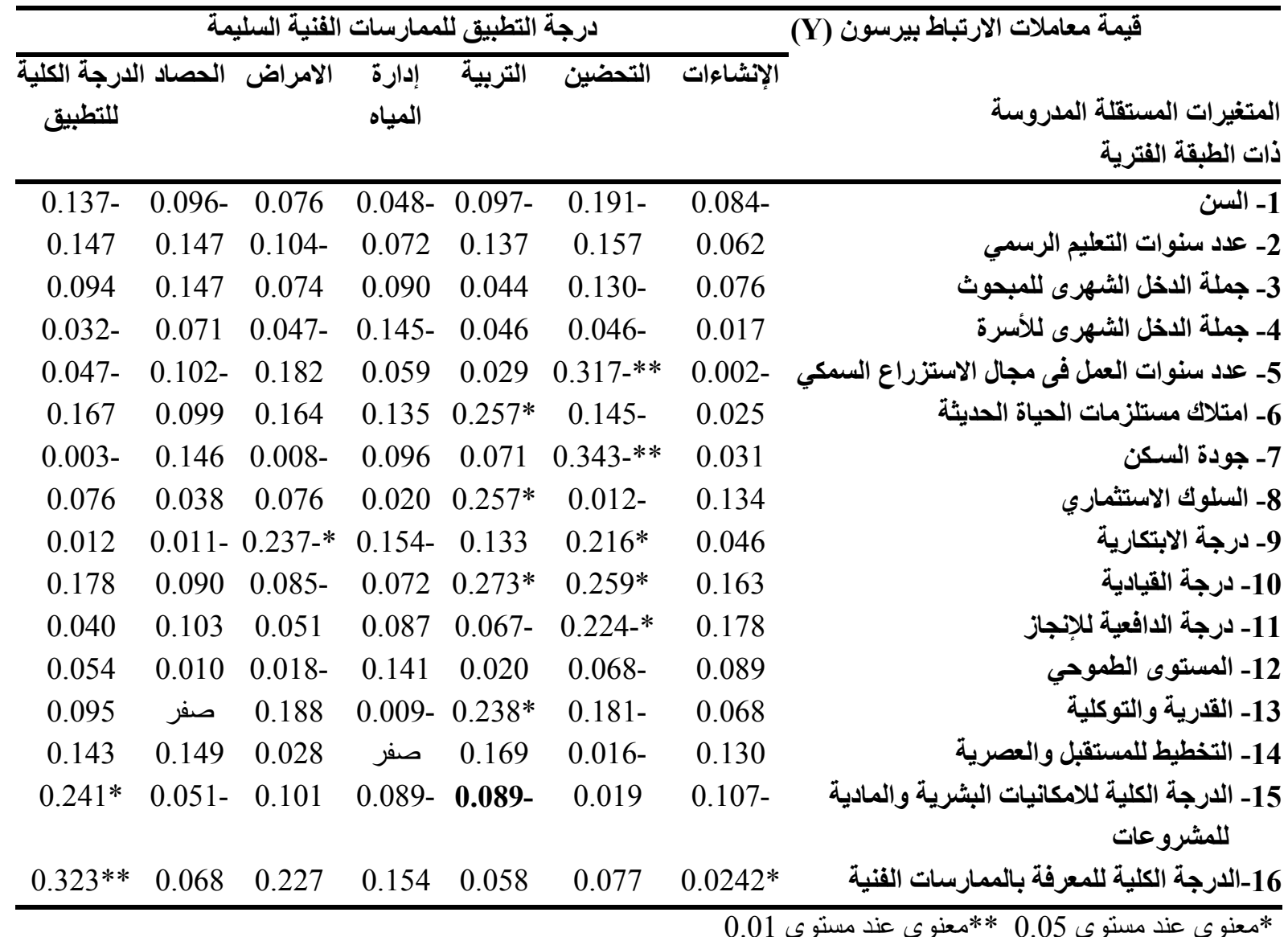

الإسهام النسبي للمتغيرات المستقلة المدروسة ذات

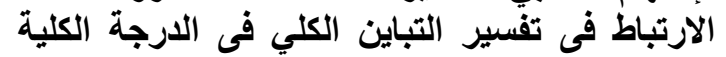

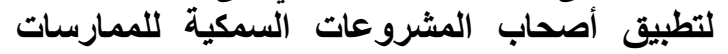

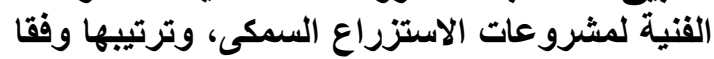
لأهميتها النسبية لمثروات الانية

لتحقيق الهدف الرابع فى الجزئية المتعلقة بتحديد

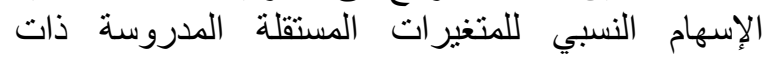

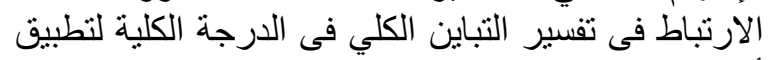

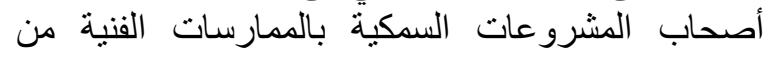

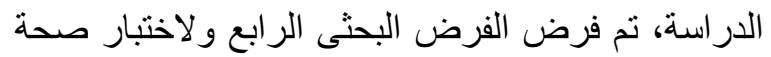

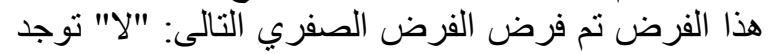

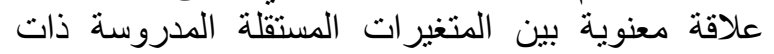

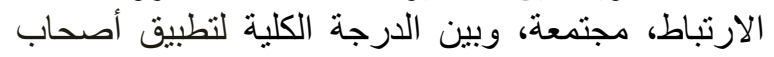

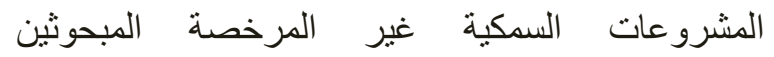

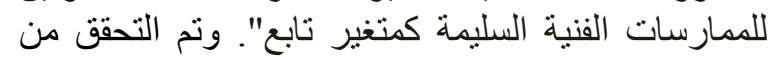

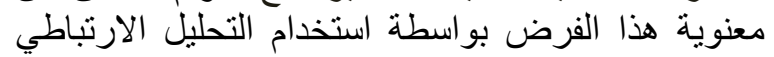

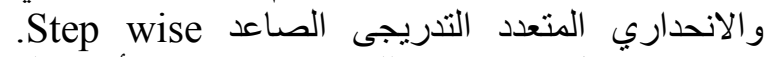

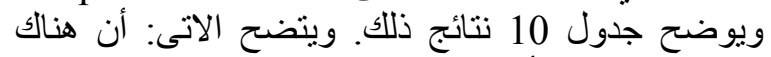
متغيرين مستقلين أسهما مجتمعان إسهاما معنويا فى تفسير النير
ويوضح جدول 9 نتائج ذلك. ويتضح الاتى: أن هناك

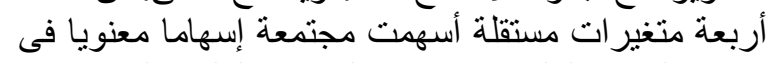

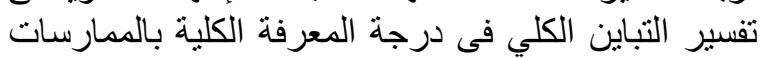

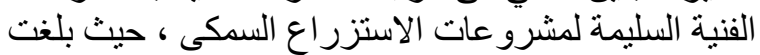

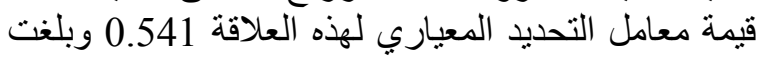

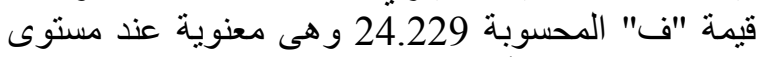

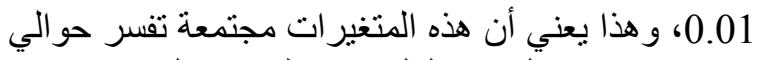

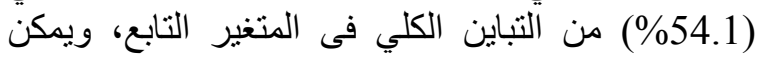

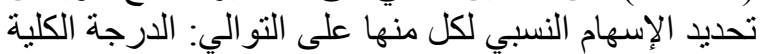

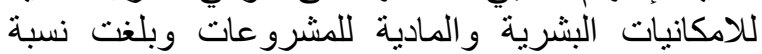

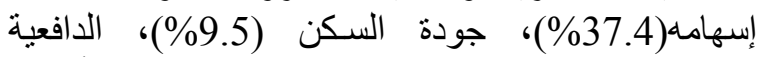
للإنجاز وبلغت نسبة إسهامه (3.81\%)، (3.40\%)، ملكية الأجهزة

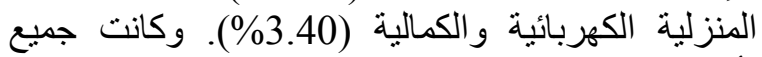

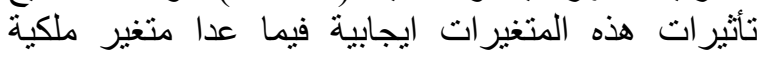
الأجهزة المنزلية الكهربائية والكمالية العالي فكان سلبيا. وبناء عليه يمكن رفض الفرض الاحصائي السابق

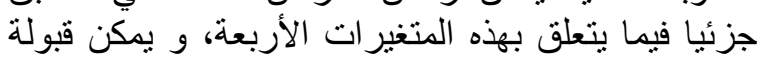

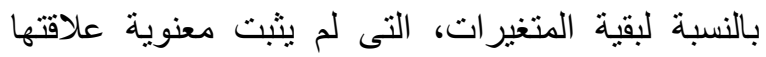
بالمتغير التابع. 
جدول 9. نتائج التحليل الإرتباطي والاتحداري المتعدد التدريجي الصاعد لعلاقة المغيرات ذات الارتباط مجتمعة بلرجة

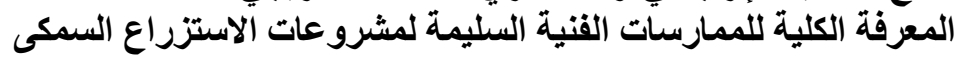

\begin{tabular}{|c|c|c|c|c|c|c|c|}
\hline \multicolumn{7}{|c|}{ المتغير التابع : الدرجة الكلية للمعرفة بالممارسـات } & \multirow{2}{*}{ المتفيرات المستقلة } \\
\hline 司 & "المستوبة & 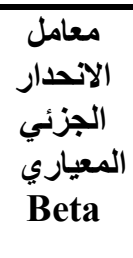 & 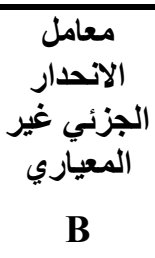 & اللتبناين التفير & 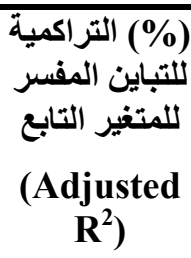 & $\begin{array}{c}\text { الارتباط } \\
\text { معاملد } \\
\text { R }\end{array}$ & \\
\hline 1 & 5.228 & 0.491 & 6.736 & 37.4 & 0.374 & 0.326 & الالدجة الكلية للامكانيات البشرية والمادية للمث \\
\hline 2 & 3.227 & 0.317 & 3.22 & 9.5 & 0.429 & 0.329 & 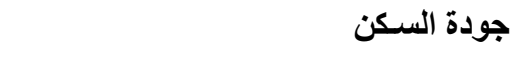 \\
\hline 3 & 2.673 & 0.262 & 2.733 & 3.81 & 0.484 & 0.337 & درجة الدافعية للإنجاز \\
\hline \multirow[t]{2}{*}{4} & $2.317-$ & $0.230-$ & $2.571-$ & 3.4 & 0.541 & 0.346 & امتلاك مستلزمات الحياة الحديثة \\
\hline & & $* * 24.22$ & ( ) المحسوبة9 & 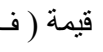 & ب. & معامل التحديد المعيار & معامل الارتباط المتعدد= 0.346 \\
\hline
\end{tabular}

جدول 10. نتائج التحليل الإرتباطي والانحداري المتعدد التّريجي الصاعد لعلاقة المغيرات ذات الارتباط، مجتمعة،

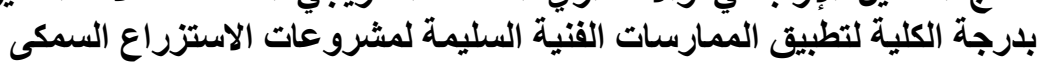

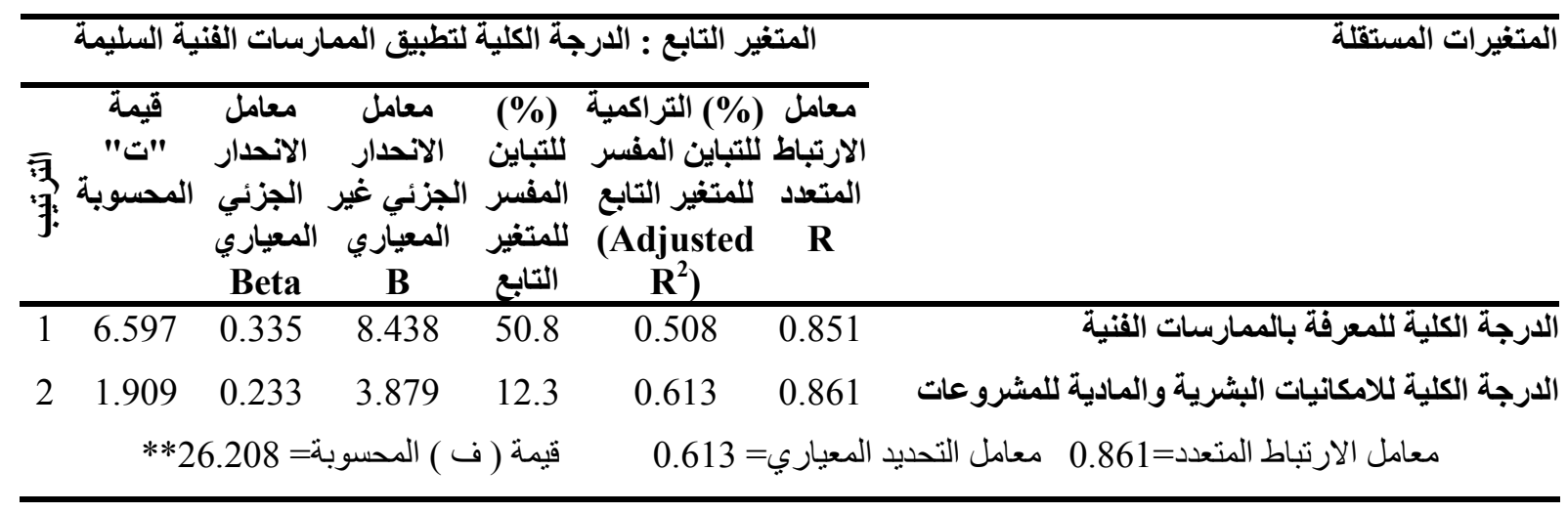

\section{توصيات الدراسة}

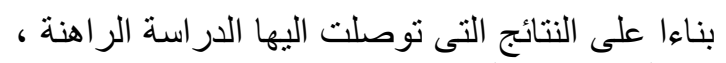
توصي الدر اسة بما يلي: 1- يجب على الهيئة العامة للرقابة على المسطحات المكاتية المائية

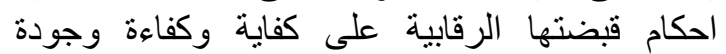

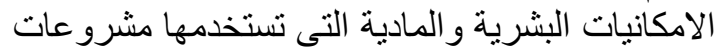
الاستزر اع السمكى غير المرخصة.

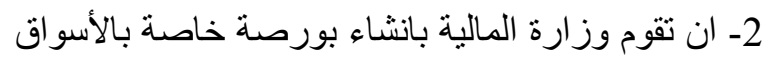

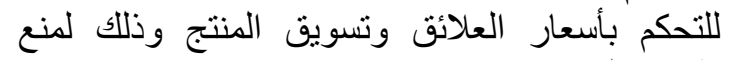
ظاهرة المحتكرين.

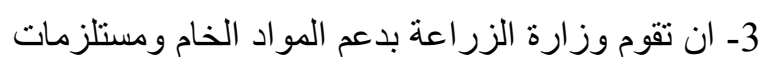

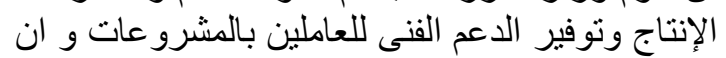

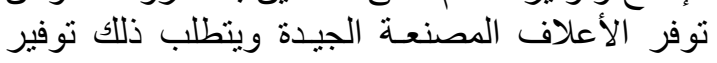

التباين الكلي فى درجة التطبيق الكلية بالممارسات الفنية

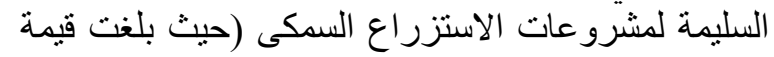

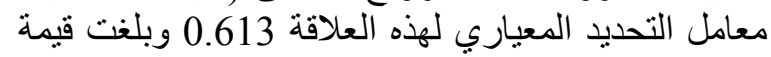
"ف" المحسوبة 26.208 وهى معنى معنوية عند مستوى النية 0.01، وهذا يعني أن هذين المتغيرين مجتمعان يفسرا

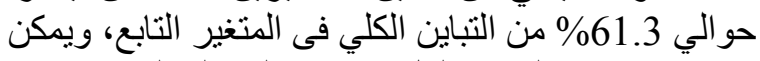

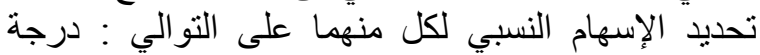

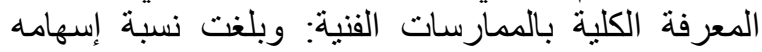
(50.8\%)، الدرجة الكلية للامكانيات البشرية والفية والمادية للمشرو عات وبلغت نسبة إسهامه (12.3\%). تأثير ات هذه المتغير ات ايجابية.

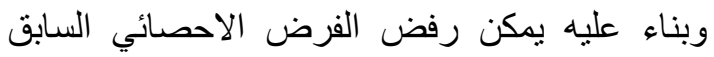

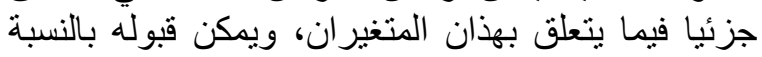

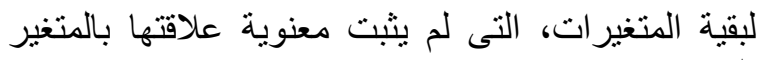


جامعة الدول العربية، (1994). الدورة التدريبية القومية لتربية الأسماك فى المية الزياه العذبة، الخرطوة التروم، مجلة التربة المنظمة العربية للتنمية الزر اعية، 14.

جامعة الدول العربية (2007). الخرطوم، مجلة المنظمة العربية للتنمية، العربة 28.

حميدة، حمزة محمد على (2013). دراسة اقتصادية

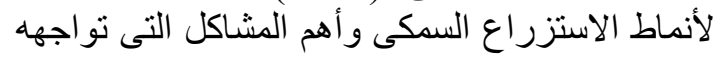

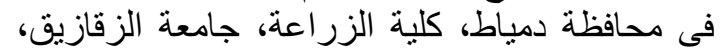
مجلة الزقازيق للبحوث الزر اعية، 31 : 64 الزراعة

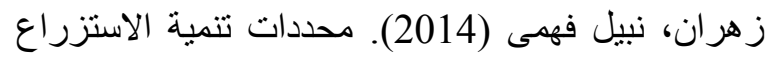

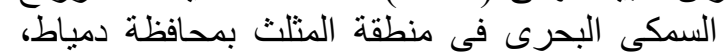
كلية الزراعة، جامعة الزقازيق، مجلة الزقازيق للبحوث

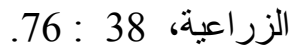

صلاح، على صلاح (1991). دراسة تحليلية للنطورات

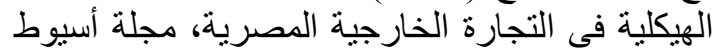
لالعلوم الزر اعية، 22 : 4.

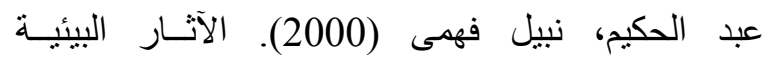

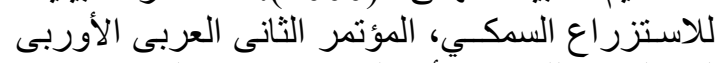

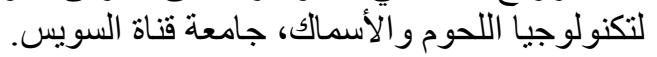

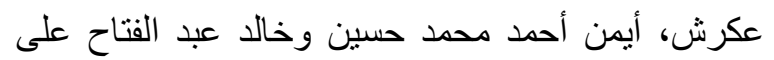

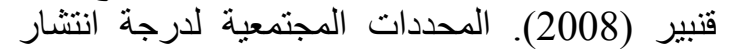

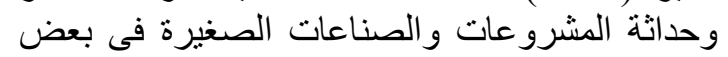

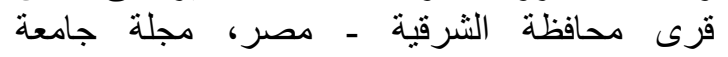
المنصورة للعلوم الزر اعية، 33 : 11.

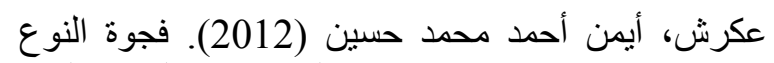
الاجتماعي فى إدارة استدامة المياه (مياه الرى و والمياه

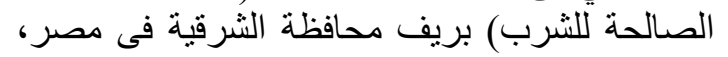

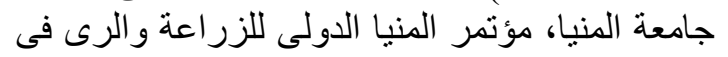

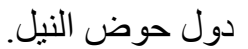

مديرية الزراعة بالثرقية (2016). قسم الثروة السمكية.

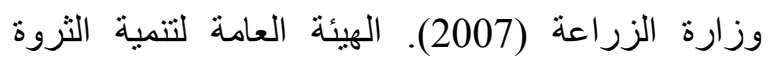
السمكية، كتاب الإحصاء السمكى السنوى.

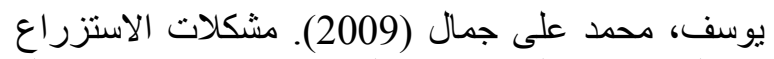

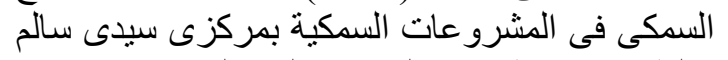

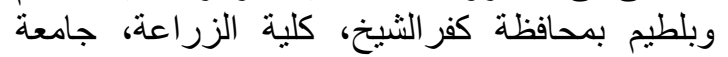
الزقازيق، مجلة البحوث الزر اعية، 36 : 56.

Liedholm (1998). The dynamics of micro and small enterprises in developing countries. World Develop., Government of India, New Delhi, $26: 1$.
المعدات التكنولوجية الحديثة اللازمة لإنشاء مصانع

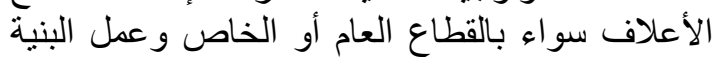

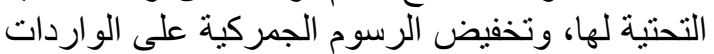

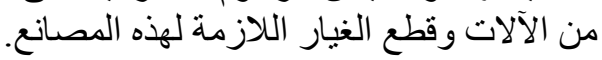

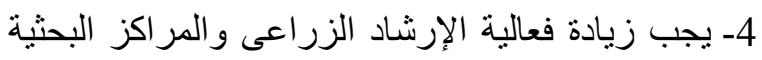

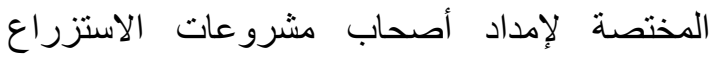

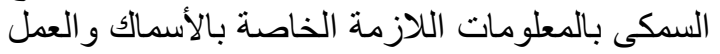

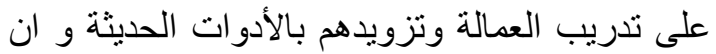

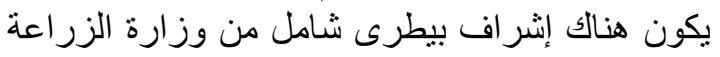
على المشروعات وحل مشكلة الأمراض ون واض القضاء عليها.

5- يجب على الهيئة العامة لتتمية الثروة السمكية أن تهتم

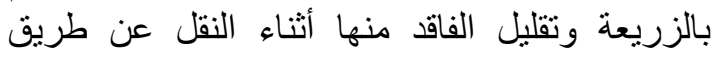

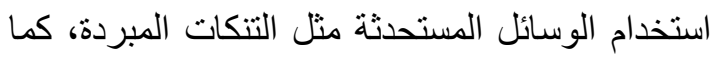

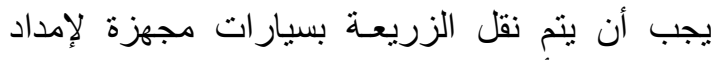

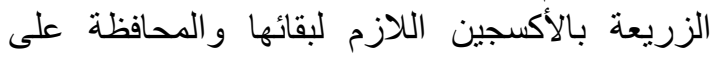

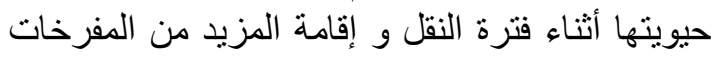

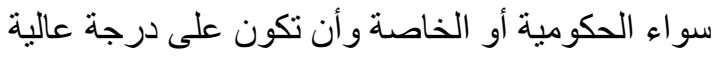
من الكفاءة بالقرب من المشرو عات السمكية. 6- ان تقوم وزارة التضامن الاجتماعى بانشاء جمعيات

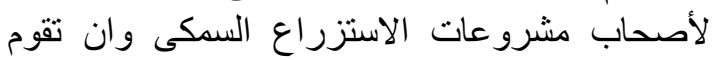
بتوفير كافة الامكانيات المادية والبشرئ البشرية لمساعدتهم على تطوير مشرو عاتهم.

\section{المراجـع}

ابر اهيم، محمد محمد سليمان و أيمن أحمد محمد حسين

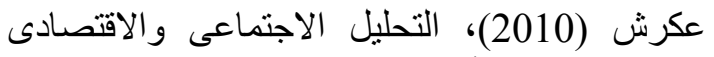
لممارسة بعض الأساليب الحديثة لصيانة البيئة المتعلقة الإنة

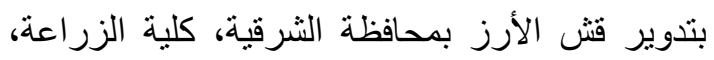

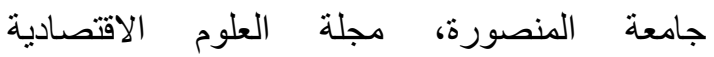
والاجتماعية الزر اعية، 1 : 11. العتربى، ناصر يوسف (2007). الاحتياجات الارشادية المعرفيه لحائزى المشروعات السمكيه بمركز سيدى الاحتي

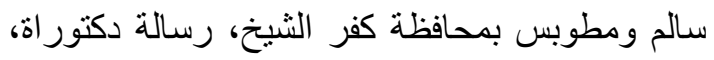
كلية الزاعة، جامعة كفر الثيخ.

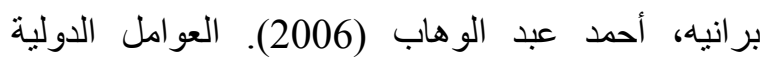

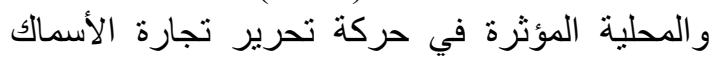

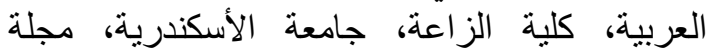
البحوث الزر اعية، 29: 35 الزعة 35. 


\title{
SOCI-ECONOMIC FACTORS AFFECTING ON LEVEL OF KNOWLEDGE AND APPLYING OF CORRECT TECHNICAL PRACTICES FOR AQUACULTURE ENTERPRISES IN SHARKIA GOVERNORATE
}

\author{
Ahmed M. Ismael ${ }^{1 *}$, A.A. Ecresh ${ }^{1}$, Sonia M-A. Nusrat ${ }^{2}$ and H.M.A.M. Sliem ${ }^{1}$ \\ 1. Branch of Rural Sociol., Agric. Econ. Dept., Fac. Agric., Zagazig Univ., Egypt \\ 2. Agric. Exten. and Rural Develop. Res. Inst., ARC., Rural Soc. Dept., Egypt
}

\begin{abstract}
The main objective of this study was to determining the important variables affected the total level of knowledge and applying related to correct technical practices of unauthorized aquaculture enterprises in Sharkia Governorate. Data were collected via face to face structured interviews by a questionnaire with a random systematic simple of 80 owner's unauthorized aquaculture enterprises in El-Hesenia District in Sharkia Governorate of Egypt (5\% of total enterprises:1602). Data collection took place from the middle of November to middle of December 2016. Findings indicated that: $56.3 \%$ of The enterprises discussed college class of human potential and its physical medium were middle, (2) $(42.5 \%),(45 \%)$ of the knowledge level of owner's unauthorized aquaculture enterprises and their applying level for the correct technical practices of these enterprises were middle, respectively; (3) Stepwise regression results showed that:(a) Only four variables (total degree of projects' human and material potential, Quality housing, motivation achievement, electronics and luxury household appliances ownership) had significant influences on total knowledge of correct technical practices of aquaculture enterprises), these variables together explained $(54.1 \%)$ of the total variation in degree of total knowledge of correct technical practices of aquaculture studied enterprises,(b) Only two variables (total degree of knowledge of technical practices, total degree of projects' human and material potential of enterprises) these variables together explained $(61.3 \%)$ of the total variation in degree of total application of correct technical practices of aquaculture studied enterprises
\end{abstract}

Key words: Technical practices in aquaculture, aquaculture enterprises, Sharkia Governorate. 